University of Texas at El Paso

\title{
DigitalCommons@UTEP
}

Open Access Theses \& Dissertations

2011-01-01

\section{Phylogeography Of Northern Populations Of The Black-Tailed Rattlesnake (crotalus Molossus Baird And Girard, 1853) With The Revalidation OfC. Ornatus Hallowell, 1854}

Christopher Anderson

University of Texas at El Paso, cganderson2@miners.utep.edu

Follow this and additional works at: https://digitalcommons.utep.edu/open_etd

Part of the Biodiversity Commons, Biology Commons, Evolution Commons, and the Zoology Commons

\section{Recommended Citation}

Anderson, Christopher, "Phylogeography Of Northern Populations Of The Black-Tailed Rattlesnake (crotalus Molossus Baird And Girard, 1853) With The Revalidation Of C. Ornatus Hallowell, 1854" (2011). Open Access Theses \& Dissertations. 2232.

https://digitalcommons.utep.edu/open_etd/2232 
PHYLOGEOGRAPHY OF NORTHERN POPULATIONS OF THE BLACKTAILED RATTLESNAKE (CROTALUS MOLOSSUS BAIRD AND GIRARD, 1853) WITH THE REVALIDATION OF C. ORNATUS HALLOWELL, 1854

\section{CHRISTOPHER G. ANDERSON}

Department of Biological Sciences

APPROVED:

Eli Greenbaum, Ph.D., Chair

Jerry Johnson, Ph.D.

Carl Lieb, Ph.D.

Richard Langford, Ph.D.

Benjamin C. Flores, Ph.D.

Acting Dean of the Graduate School 


\section{Copyright (C)}

by

Christopher G. Anderson

2011 


\title{
PHYLOGEOGRAPHY OF NORTHERN POPULATIONS OF THE BLACK- TAILED RATTLESNAKE (CROTALUS MOLOSSUS BAIRD AND GIRARD, 1853) WITH THE REVALIDATION OF C. ORNATUS HALLOWELL, 1854
}

CHRISTOPHER G. ANDERSON, B. Sc.

\author{
THESIS \\ Presented to the Faculty of the Graduate School of \\ The University of Texas at El Paso \\ in Partial Fulfillment \\ of the Requirements \\ for the Degree of \\ MASTER OF SCIENCE \\ Department of Biological Sciences \\ THE UNIVERSITY OF TEXAS AT EL PASO
}

December 2011 


\section{ACKNOWLEDGEMENTS}

First I would like to thank my family for their continual love and support, without them I would not be the person that I am today. My father introduced me to the diversity of the natural environment and taught me about natural history as a child, and continues to be an inspiration. My mother and stepfather have been incredible role models and have taught me the importance of hard work. My wife has always been there to support and encourage me, and has been an invaluable field companion on many collections trips.

I would like to thank my graduate committee Dr. Eli Greenbaum, Dr. Jerry Johnson, Dr. Rip Langford and Dr. Carl Lieb without whom this research would not have been possible. I would especially like to thank my thesis advisor Dr. Eli Greenbaum who took me on as one of his first graduate students, entertained my need to incorporate fieldwork into my research and provided exceptional guidance in an area of biology where I had very little experience; Dr. Carl Lieb for helping me locate specimens in the UTEP herpetology collection and for his in-depth discussions of Chihuahuan Desert biogeography; and Dr. Jerry Johnson for help with the formulation of this thesis and his eagerness to share his opinions.

I would also like to thank Dr. Robert Webb who helped me find obscure locality data and publications; Dr. Vanessa Lougheed for her explanation of principal components analyses; Cesar Villanueva who trained me in laboratory procedures; Katrina Weber and Federico Valdez for support and advice.

An important component of this thesis relied on the examination of specimens accessioned in natural history collections outside of UTEP. I thank Dr. Eric Smith and Carl Franklin for tissue samples and access to the UTA herpetology collection; Christian Cox, Jeff Streicher and Ben Anders for entertainment and accommodations while visiting UTA; Addison 
Wynn and Jeremy Jacobs for access to material at USNM; and Rafe Brown and Andrew Campbell for loaned material from the KU Natural History Museum.

DNA samples were sequenced by Omar Hernandez, Dr. Carolina Lema and Ana Betancourt at the UTEP DNA Analysis Core Facility (funded by NIH grant \#5G12RR008124). Additional funding was provided by the UTEP Graduate School, Department of Biological Sciences and College of Sciences. 


\section{ABSTRACT}

The black-tailed rattlesnake (Crotalus molossus Baird and Girard, 1853) is a wide-ranging species complex with representatives from the southwestern United States through the highlands of central and southern Mexico. The systematics of this group has received little attention and in the past six decades only two taxonomic revisions have been proposed (the transfer of $C$. basiliscus oaxacus to C. molossus and the elevation of C. m. estebanensis to full species). However, a recent revision of the Neotropical rattlesnakes (C. durissus and C. simus) recovered a polyphyletic C. molossus. Sequenced data were obtained from three mitochondrial genes (ATPases 8 and 6, cyt $b$ and ND4) and three nuclear genes (c-mos, EXPH5 and RAG1) to examine phylogenetic relationships among $C$. molossus lineages and the closely related species C. basiliscus and C.totonacus. Results recovered strong support for two deeply divergent and polyphyletic northern C. molossus lineages that are morphologically distinct. Biogeographical patterns and divergence dates inferred from mitochondrial data suggest the diversification of $C$. molossus is the result of a Neogene vicariance event associated with uplift of the Sierra Madre Occidental. Population-level analyses suggested that major lineages of C. molossus have been stable since their initial divergence. On the basis of morphological and molecular evidence I propose that the synonym Crotalus ornatus Hallowell 1854 be resurrected and applied to populations in the Chihuahuan Desert and central Texas. This thesis represents the most complete phylogenetic analysis of any member of the C. molossus group and demonstrates discordance between the contemporary taxonomy of the group and its true diversity. 


\section{TABLE OF CONTENTS}

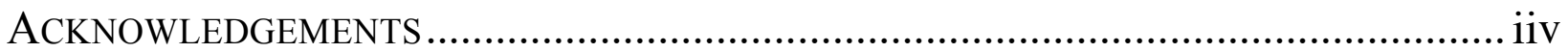

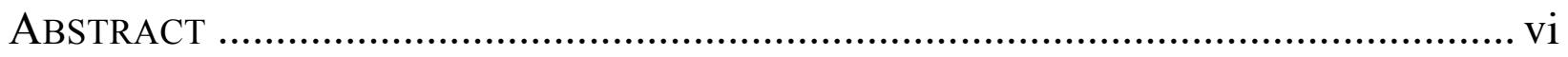

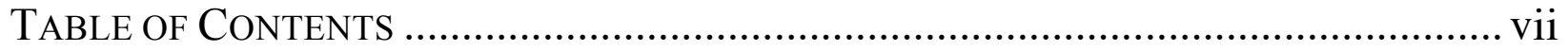

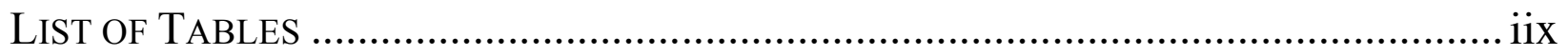

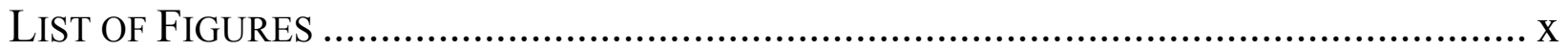

CHAPTER 1: GENERAL INTRODUCTION .................................................................. 1

1.1 INTRODUCTION TO THE FAMILY VIPERIDAE .............................................. 1

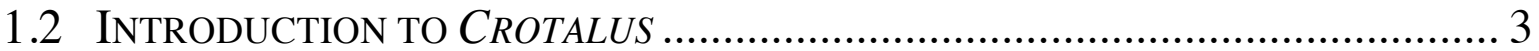

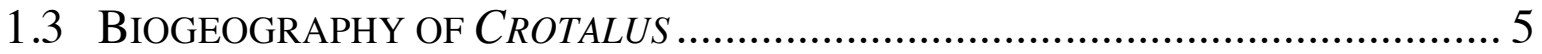

1.4 SYSTEMATICS AND TAXONOMY OF CROTALUS ........................................ 6

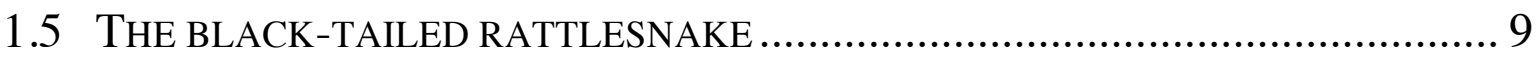

1.6 SYSTEMATICS OF THE BLACK-TAILED RATTLESNAKE ................................ 13

1.7 RESEARCH FOCUS AND OBJECTIVES ..................................................... 16

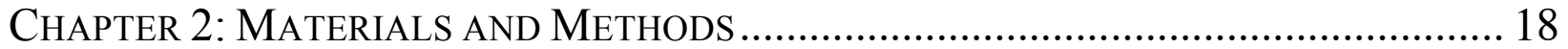

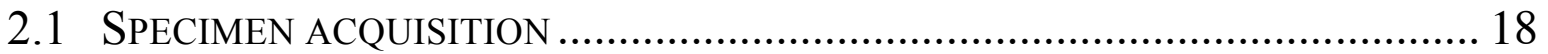

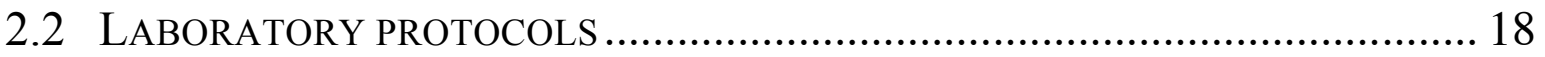

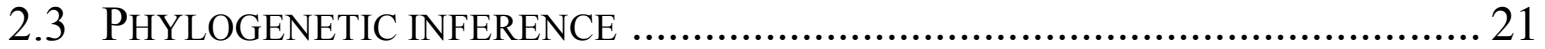

2.4 GENETIC DIVERGENCE AND MONOPHYLY TESTS ................................... 23

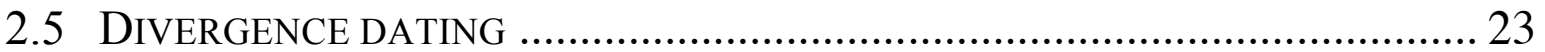

2.6 PoPUlATION AND GEOGRAPHIC STRUCTURE ANALYSIS ............................. 25

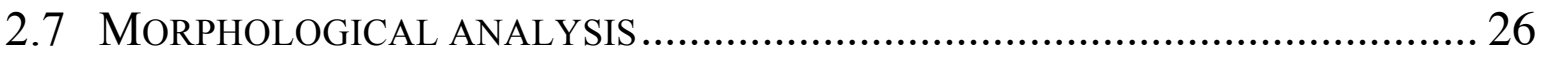

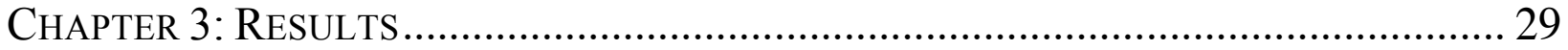

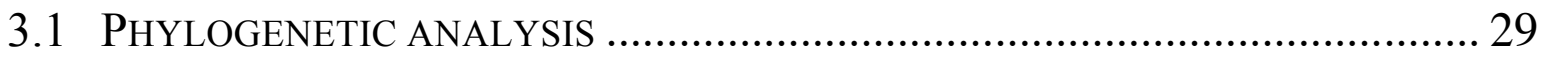

3.2 GENETIC DIVERGENCE AND HYPOTHESIS TESTS ....................................... 36

3.3 PoPUlation AND GEOGRAPHIC STRUCTURE ANALYSIS ............................ 37

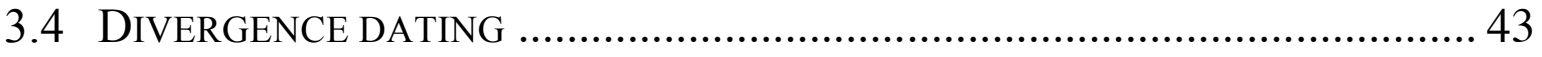




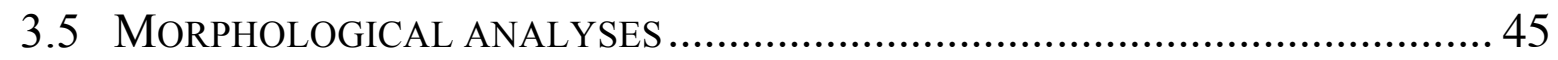

3.6 TAXONOMY OF CROTALUS MOLOSSUS ....................................................... 51

3.7 TAXONOMY OF CROTALUS MOLOSSUS SENSU STRICTO ............................... 52

3.8 REDISCRIPTION OF CROTALUS ORNATUS ............................................... 53

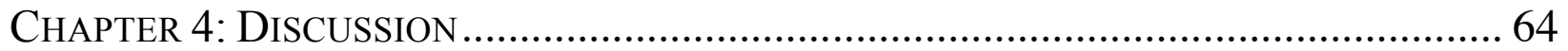

4.1 Phylogeny AND taXonomic Status of CROTALUS MOLOSSUS ................ 64

4.2 Biogeography OF CROTALUS MOLOSSUS AND CROTALUS ORNATUS ......... 66

4.3 The CRotalus molossus Group at the Cochise Filter Barrier ......... 68

4.4 INTROGRESSION AND INCOMPLETE LINEAGE SORTING ............................. 70

4.5 CONCLUSIONS AND FUTURE DIRECTIONS ................................................. 72

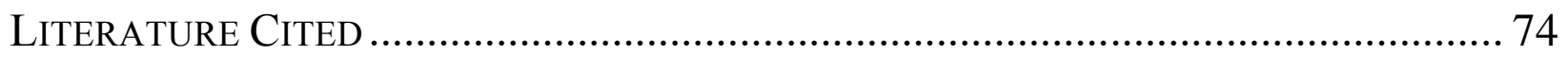

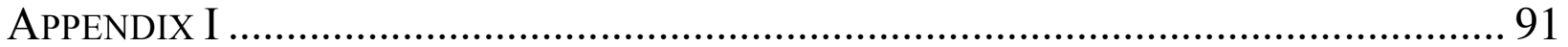

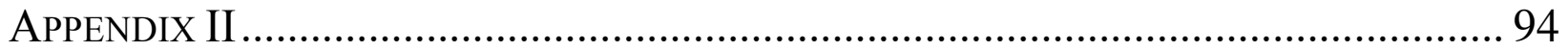

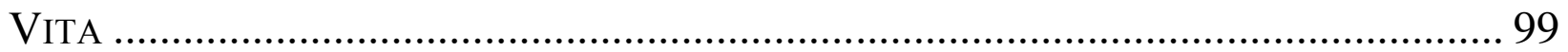




\section{LIST OF TABLES}

Table 2.2.1 List of primers used for amplification and sequencing of each fragment................20

Table 3.1.1 Nucleotide substitution model parameters.......................................................30

Table 3.2.1 Uncorrected $p$-distances within and among groups of Crotalus molossus...............37

Table 3.3.1 Genetic diversity estimates and neutrality tests within populations of Crotalus

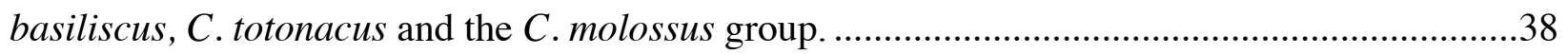

Table 3.3.2 Hierarchical analysis of molecular variance among lineages in the Crotalus

molossus group.

Table 3.5.1 Descriptive statistics obtained from regressed meristic data for the eastern and

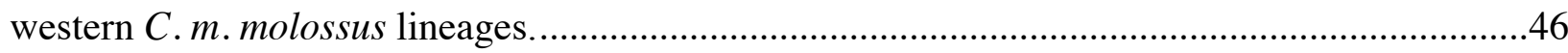

Table 3.5.2 Descriptive statistics obtained from meristic data for the eastern and western C. $m$.

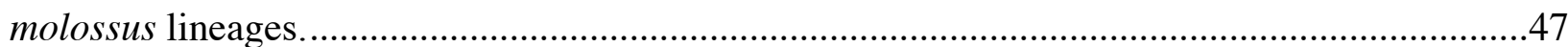

Table 3.5.3 Eigenvalues and PC loadings obtained from a PCA of morphometric data. ............50

Table 3.5.4 Eigenvalues and PC loadings obtained from a PCA of raw meristic data................50 


\section{LIST OF FIGURES}

Figure 1.5.1 Geographic distribution of the Crotalus molossus group.......................................10

Figure 1.6.1 Phylogenetic relationships among lineages of the Crotalus molossus group. .........15

Figure 3.1.1 Phylogeny inferred from the combined mtDNA dataset........................................32

Figure 3.1.2 Phylogeny inferred from the combined six-gene dataset. ........................................33

Figure 3.1.3 Sampling localities and geographically defined clades recovered in haplotype and phylogenetic analyses.

Figure 3.1.4 Phylogenetic trees inferred from single gene nDNA datasets c-mos, EXPH5 and

RAG1.

Figure 3.3.1 Mismatch distributions computed from mtDNA, c-mos, EXPH5 and RAG1 datasets.

Figure 3.3.2 Haplotype networks for Crotalus m. molossus, calculated from the mtDNA dataset.

Figure 3.4.1 Cladogram with estimated divergence times for the major lineages within the Crotalus molossus group.

Figure 3.5.1 Score plots of first and second principal components obtained from PCA of morphometric data.

Figure 3.5.2 Score plots of first and second principal components obtained from PCA of raw meristic data.

Figure 3.8.1 Photographs of the holotype of Crotalus ornatus.

Figure 3.8.2 Photographs of Crotalus ornatus and C. molossus in life. 


\section{CHAPTER 1: GENERAL INTRODUCTION}

\subsection{INTRODUCTION TO THE FAMILY VIPERIDAE}

The Viperidae is a diverse and highly derived group united by the solenoglyphous condition, in which a large canaliculated fang is attached to a highly kinetic maxillary bone that is used for the delivery of venom. Vipers have been the focus of a plethora of research spanning the disciplines of ecology, physiology, systematics, functional morphology, behavior, development and medicine (e.g., Scheut and Grober 2000; Greenbaum 2004; Meik and PiresdaSilva 2009). The functional morphology of the viperid venom apparatus has received a great deal of attention by the scientific community (e.g., Kardong 1982; Vonk et al. 2008). Venom components have garnered much attention among medical researchers, particularly in the treatment of envenomation in humans and potential pharmaceutical applications, making the Viperidae an extremely important taxon in medicine. Norris (2004) and Warrell (2004) provided extensive discussions of medical implications in North America and South America, respectively.

Systematics of the Viperidae has been the focus of many previous studies, and higherlevel relationships are relatively well understood. Monophyly of the vipers is unchallenged and their phylogenetic position near the base of the Colubroidea (the superfamily including the Xenodontidae, Pareatidae, Viperidae, Elapidae and all historical and current members of the Colubridae) has been supported by several recent molecular studies (Kelly et al. 2003; Wiens et al. 2008; Zaher et al. 2009; Pyron et al. 2011). Since their divergence from the remaining Colubroidea in the early to mid- Paleogene (67-38 million years ago [mya]) (Wüster et al. 2008; 
Vidal et al. 2009), the vipers diversified into 295 extant species in three subfamilies: the Viperinae (true vipers, 13 genera), Azemiopinae (Feae's viper, one monotypic genus) and the Crotalinae (pitvipers, 30 genera). Relationships between the subfamilies are widely accepted and supported by morphological and molecular evidence (Campbell and Lamar 2004). Previously, Azemiopinae and Causinae (the African genus Causus) were presumed to be basal viperids (Liem et al. 1971; Groombridge 1986). Consequently, several authors have erroneously assigned Causus as an outgroup in studies focused on the Viperinae (e.g., Herman et al. 1999; Lenk et al. 2001). However, subsequent molecular analyses have shown Causus to be nested within the Viperinae (Wüster et al. 2008; Pyron et al. 2011), and Azemiopinae was identified as the sister group to the Crotalinae, a relationship first suggested by Cadle (1992) and later supported by molecular data (Kelly et al. 2003; Wiens et al. 2008; Wüster et al. 2008; Pyron et al. 2011). In spite of recent advances in viperid systematics, the geographical origin of the Viperidae remains undefined, but molecular and biogeographical data suggest an Asian origin for the family (Wüster et al. 2008).

The Viperidae is a wide-ranging family with representatives occupying a variety of ecological niches throughout tropical and temperate regions worldwide, exclusive of many oceanic islands (e.g., the Hawaiian and Galapagos islands) and the landmasses south of Wallace's line (i.e., southeast Indonesia, Australia and New Zealand). The Viperinae ( $\sim 88$ species) is widespread through most of Africa, Europe, the Middle East, India and islands of the Sunda Shelf in Southeast Asia. Azemiopinae is a monotypic taxon represented by Azemiops feae from southern China and adjacent portions of Vietnam and Myanmar. The 206 species in the Crotalinae are distributed through Indonesia, Asia and the Americas, with one species (Gloydius halys) present in southeastern Europe. Only the Crotalinae were able to invade the New World. 
The exceptional diversity of pitvipers in the Americas is the result of a single species, a member of the lineage that gave rise to the Asian genus Gloydius, which entered North America through Beringia (Malhotra et al. 2010). A specific date for this interchange is unclear. However, the most recent estimates suggest that pitvipers entered the Americas in the late Oligocene or early Miocene (14-27 mya) (Wüster et al. 2008; Castoe et al. 2009), a date that closely follows the invasion of the New World by the Lampropeltini snakes (Burbrink and Lawson 2007). Global cooling beginning at the Eocene-Oligocene boundary transformed the Beringian climate, reducing the wide subtropical forest to a narrow band of boreal forest by the mid-Miocene (Sanmartin et al. 2001). This cooling would have effectively stopped the exchange of squamate groups through the Bering Land Bridge. Fossils representing Agkistrodon, Crotalus and Sistrurus appear in central North America by the mid- to late Miocene ( 9 mya), and fossils of unidentified viperid species are present in early Miocene deposits from Nebraska (Parmley and Holman 2007). Additionally, molecular data suggest that most New World pitviper genera diverged by the mid-Miocene (Castoe et al. 2009; Wüster et al. 2008). In the Americas, pitvipers underwent a massive radiation, resulting in 14 genera and 117 species occurring throughout southern North America and the Neotropics. One of these groups, the rattlesnakes (Crotalus and Sistrurus), has experienced an extensive diversification in temperate North America (Campbell and Lamar 2004).

\subsection{INTRODUCTION TO CROTALUS}

Thirty-five species of Crotalus (Alvarado-Diaz and Campbell 2004; Wüster et al. 2005; Quijada-Mascareñas and Wüster 2006; Douglas et al. 2007; Beaman and Hayes 2008; Campbell and Flores-Villela 2008) occupy a range from southern Canada through the continental United 
States to western Costa Rica and South America east of the Andes (Campbell and Lamar 2004). The phylogenetic position of the rattlesnakes within the Viperidae is stable, with the genus Agkistrodon consistently placed as sister to the rattlesnakes, and monophyly of the group is supported by both morphological and molecular evidence (e.g., Campbell and Lamar 2004; Castoe and Parkinson 2006; Wüster et al. 2008; Meik and Pires-daSilva 2009). The rattlesnakes are distinguished from other New World pitvipers by several synapomorphies, including: (1) lack of a nasal pore; (2) position of the loreal pit below the naso-ocular line; and (3) the rattle. The rattle and structures associated with it are sufficient to unite all members of Crotalus and Sistrurus in a monophyletic group (Campbell and Lamar 2004). Meik and Pires-daSilva (2009) separated rattlesnakes from other New World pitvipers by the numbers of caudal and precloacal vertebrae. In rattlesnakes, incorporation of caudal vertebrae into the style (the fused caudal vertebrae associated with the rattle and rattle matrix) results in a trend toward fewer caudal vertebrae and a shorter tail. Unfortunately, character states of the style do not appear to be useful in addressing relationships between rattlesnake species (Meik and Pires-daSilva 2009).

Previously, the presence of nine large head plates (absent in Crotalus) was thought to be a synapomorphy distinguishing the members of Sistrurus from Crotalus (Campbell and Lamar 2004). However, molecular analyses by Murphy et al. (2002) indicated that Sistrurus ravus (a taxon with nine large head plates) is better placed at the base of the Crotalus tree, and these authors subsequently suggested a taxonomic revision to reflect this. Campbell and Lamar (2004) upheld this reclassification, but noted the uncertainty surrounding the actual position of C. ravus within Crotalus. This taxonomic revision was not unexpected, as the monophyly of Sistrurus (with respect to ravus) had been questioned on previous occasions (e.g., Foote and McMahon 1977; Minton 1992). As is often the case in snake classification, hemipenis morphology is a 
good diagnostic tool for distinguishing Crotalus from Sistrurus. In Crotalus, the hemipenes are usually slightly longer (8-12 subcaudals in length when everted versus 5-10 in Sistrurus) and with few exceptions, basal spines abruptly transition to calyces, which are small pockets between retiform ridges on the hemipenis. In the case of Sistrurus, basal spines grade into calyces (Campbell and Lamar 2004).

\subsection{BIOGEOGRAPHY OF CROTALUS}

It is likely that after its introduction to the New World, the ancestor of the American pitvipers would have rapidly expanded its range through southern North America and Central America. The initial divergence in this region resulted in a Central American bothrapoid group (the ancestor of Atropoides, Bothriechis, Bothriopsis, Bothrocophias, Bothropoides, Bothrops, Cerrophidion and Porthidium) and a North American/Mexican lineage (the ancestor of Agkistrodon, Crotalus, Lachesis, Ophryacus and Sistrurus). Shortly after this initial divergence, the North American lineage split, resulting in an Ophryacus-Lachesis group in southern Mexico and Central America, and an Agkistrodon-like lineage in Mexico. In the early Miocene, this Agkistrodon-like lineage underwent a divergence between populations in the Mexican lowlands and the Mexican plateau, which resulted in the divergence of the rattlesnakes (Crotalus and Sistrurus) from Agkistrodon (Gutberlet and Harvey 2004). It should be noted here that a recent study by Jaden et al. (2011) erected the genus Mixcoatlus to remedy the paraphyly of Agkistrodon, Cerrophidion and Ophryacus caused by the poorly known A. browni. This revision to the taxonomy of Middle American pitvipers places A. browni, C. barbouri and O. melanurus in the genus Mixcoatlus, which is sister to the now monotypic Ophryacus undulatus (Jadin et al. 2011). 
The genus Crotalus reaches its greatest diversity in the vicinity of the Mexican plateau and adjacent mountain ranges. This region of central Mexico is generally viewed as the origin of the rattlesnakes (e.g., Murphy et al. 2002; Campbell and Lamar 2004; Place and Abramson 2004), a hypothesis supported by the basal position of many of the species groups that currently occupy the region, including $C$. polystictus, C. ravus and C. triseriatus (Klauber 1972; Murphy et al. 2002; Castoe and Parkinson 2006). The earliest rattlesnake fossils from the Miocene of Nebraska (Parmley and Holman 2007) and recent molecular data (Kubatco et al. 2011) suggest that the genus Sistrurus diverged and expanded into the Great Plains by the mid-Miocene (9-13 mya), and many of the major species groups within Crotalus would have been present by the mid- to late Miocene (Douglas et al. 2006; Wüster et al. 2008; Castoe et al. 2009).

\subsection{SYSTEMATICS AND TAXONOMY OF CROTALUS}

From a taxonomic standpoint, Crotalus has been relatively stable with only one recent attempt to reclassify the genus. Hoser (2009a) split Crotalus into eight genera (Crotalus, three synonyms of Crotalus and four new genera) based on his interpretation of a handful of contributions to rattlesnake systematics, particularly from the work of Murphy et al. (2002) and Campbell and Lamar (2004). This review, and Hoser's recent work in general, has garnered a great deal of scrutiny from snake taxonomists. Many criticized his arguments for reclassification, and some have questioned the validity of his publication outlet, The Australian Journal of Herpetology (AJH). In response to Hoser's review of the cobras (Hoser 2009b), Wallach et al. (2009) provided a detailed account of AJH and the complicated procedure involved in acquiring a printed version; this ultimately led the authors to the conclusion that the publication does not meet the requirements set forth by the International Code of Zoological Nomenclature, making 
the names published therein unavailable. However, it should be noted that a long-standing rivalry (outlined in Hoser 2009c) seems to exist between Hoser and a number of snake taxonomists, including at least one of the coauthors of Wallach et al. (2009). This seems to have begun with a review of the elapid genus Acanthophis (Hoser 1998), in which five new species and one new subspecies were described, one of which (A. wellsi) is now considered valid. Subsequently, Wüster et al. (2001), Williams et al. (2006) and Wallach et al. (2009) detailed serious flaws in Hoser's methods, including scant evidence in support of reclassification and poor species diagnoses. The arguments for reclassification of the rattlesnakes as presented by Hoser (2009a) do not seem to demonstrate a comprehensive understanding of phylogenetics or a thorough investigation of the existing literature. For example, Hoser assigned the genus Aechmophrys to a group comprised of Crotalus cerastes, C. intermedius, C. polystictus, C. pricei, $C$.tancitarensis, $C$. transversus and $C$. willardi. Murphy et al. (2002), the study on which most of Hoser's conclusions seem to be based, only recognized this grouping in the preferred phylogeny after accounting for morphological evidence, and failed to recover this group in any of their unweighted parsimony analyses. Moreover, studies that inferred relationships differing from the preferred phylogeny of Murphy et al. (2002) seem to have been ignored (e.g., Parkinson 1999; Parkinson et al. 2002; Castoe and Parkinson 2006).

While not fully resolved, there has been little contention regarding phylogenetic relationships within Crotalus. By and large, similar clades and topologies are recognized across multiple morphological and molecular studies (e.g., Klauber 1972; Murphy et al. 2002; Campbell and Lamar 2004). There are, however, some notable exceptions between the two most complete phylogenetic treatments of the rattlesnakes (i.e., Castoe and Parkinson 2006; Murphy et al. 2002). For example, Castoe and Parkinson (2006) identified C. polystictus as the basal taxon in 
Crotalus, not C. ravus (previously Sistrurus ravus) as presented in the preferred phylogeny of Murphy et al. (2002). Additional discrepancies exist between these two studies, notably the placement of $C$. adamanteus, $C$. enyo, $C$. horridus and $C$. willardi. In both cases, the authors used the same mitochondrial genes to examine relationships between representatives of the same 27 rattlesnake species, but the two studies implemented different approaches. Murphy et al. (2002) only sought to address relationships among the rattlesnakes, whereas Castoe and Parkinson (2006) examined relationships between 116 Old and New World pitviper species. Murphy et al. (2002) examined one additional gene (resulting in $2.9 \mathrm{~kb}$ versus $2.3 \mathrm{~kb}$ ) with maximum parsimony (MP) analyses, whereas Castoe and Parkinson (2006) implemented MP and Bayesian (partitioned and unpartitioned) analyses. In their MP analysis, Castoe and Parkinson (2006) recovered weak support for clades within Crotalus and inferred Agkistrodon as the sister to Lachesis and Ophryacus that, together, form a clade that is sister to the rattlesnakes. The partitioned Bayesian analysis of the latter study recovered a phylogeny more typical of relationships proposed by previous investigators, with Agkistrodon inferred as sister to the rattlesnakes, albeit with low support. To date, no study has implemented nuclear markers to address large-scale relationships within the genus Crotalus. However, recent studies focusing on Sistrurus (Gibbs and Diaz 2010; Kubatko et al. 2011) have identified a number of nuclear markers that seem to be useful in identifying species-level divergence in Sistrurus and possible other North American pitviper taxa. Furthermore, there has yet to be a phylogenetic analysis that includes all members of the genus Crotalus. Paucity of specimens, unfamiliarity with their natural history, and the recent discovery of one species have prevented the inclusion of the longtailed rattlesnakes (C. ericsmithi, C. lannomi and C. stejnegeri) in any recent phylogenetic analysis of the genus. Most contention regarding Crotalus systematics is associated with fine- 
scale problems concerning species complexes, and many distinct species may still be obscured by outdated subspecies taxonomy.

The application of modern molecular techniques has demonstrated deep divergences within species complexes (e.g., Pook et al. 2000; Ashton and de Queiroz 2001; Douglas et al. 2002) and in some cases, identified them as paraphyletic or polyphyletic (e.g., Wüster et al. 2005). Amid the recent push to eliminate the outdated subspecies classification (Collins 1991), several large species complexes within Crotalus have received a great deal of attention. A review of $C$. mitchellii by Douglas et al. (2007) resulted in the authors arguing for the elevation of $C$. mitchellii stephansi to species status. Concurrent phylogeographic analyses of $C$. viridis (Pook et al. 2000; Ashton and de Queiroz 2001; Douglas et al. 2002) resulted in the reclassification of the $C$. viridis species complex into three species (Beaman and Hays 2008) (seven species are recognized by Collins and Taggart [2009]). Additionally, taxonomic arguments by Campbell and Lamar (2004), Savage et al. (2005) and Quijada-Mascareñas and Wüster (2006), and phylogeographic evidence presented by Wüster et al. (2005) have resulted in the elevation of four lineages of the Neotropical rattlesnake (C.durissus) to species status. The latter study also identified incongruence between the taxonomy and phylogenetic relationships of the black-tailed rattlesnake ( $C$. molossus), suggesting the group likely represents a species complex.

\subsection{THE BLACK-TAILED RATTLESNAKE}

Crotalus molossus Baird and Girard 1853, commonly known as the black-tailed rattlesnake, is a wide-ranging complex of four subspecies (Fig. 1.5.1). The southernmost taxon C. m. oaxacus Gloyd 1948 (Campbell and Lamar 1989) occurs in Oaxaca and southeastern 
Puebla, Mexico, C. m. nigrescens Gloyd 1936 ranges from Michoacán and northern Puebla through much of central Mexico as far north as west-central Chihuahua, C. m. estebanensis Klauber 1949 (elevated to a full species by Grismer 1999) occurs only on Isla San Esteban in the Gulf of California, and C. m. molossus Gloyd 1936 ranges from the Mexican states of Sonora,

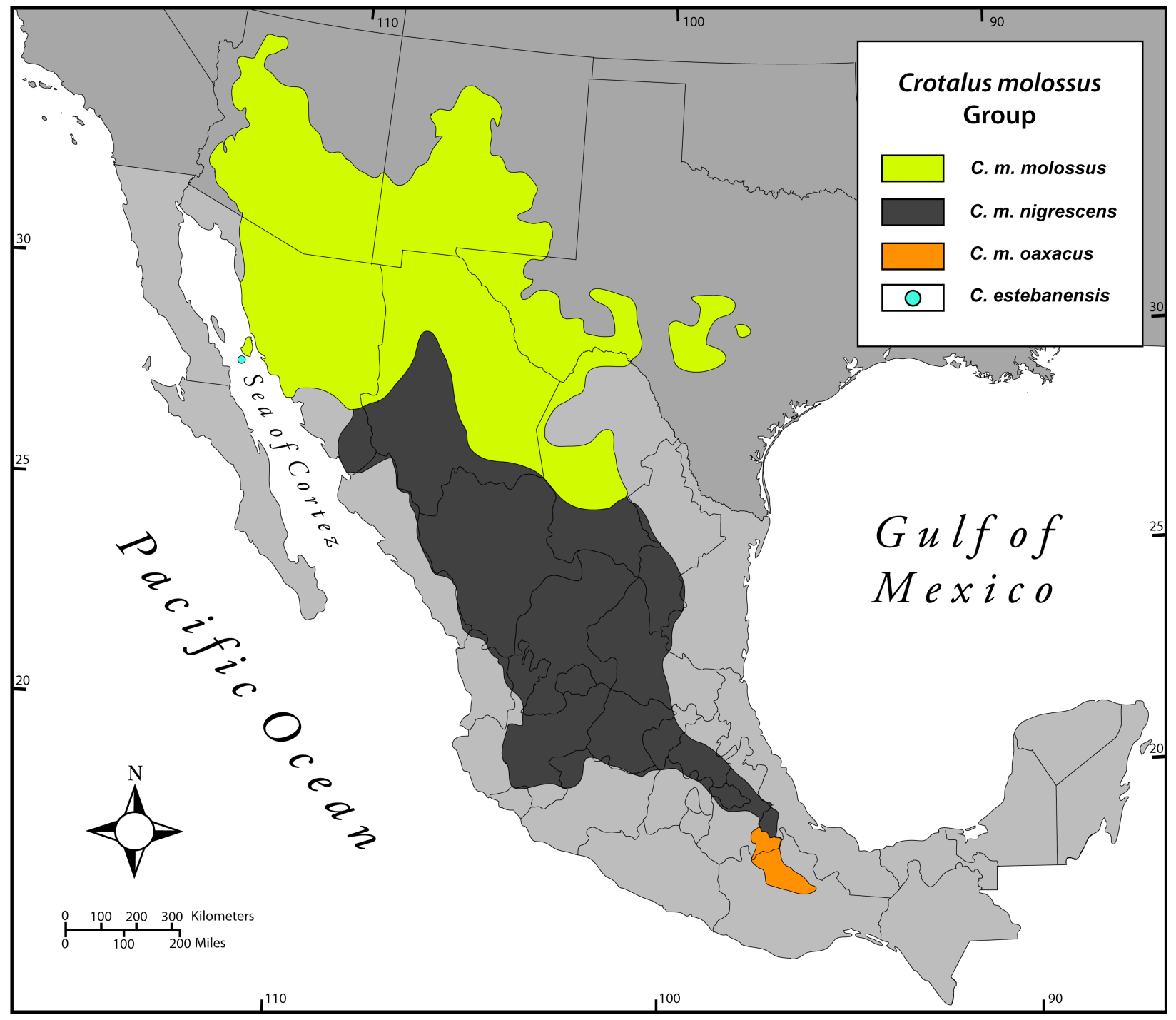

Figure 1.5.1 Geographic distribution of the Crotalus molossus group. Modified from a map by Campbell and Lamar (2004). 
Chihuahua and Coahuila to central Texas, New Mexico and Arizona (Campbell and Lamar 2004). Throughout this wide geographic range, the black-tailed rattlesnake is a habitat generalist with a strong affinity for rocky terrain, and is often found in or near canyons, cliffs or talus slopes. Elevation records range from near sea level to 2,930 meters (m). Plant associations vary from pine-oak and tropical dry forests to mesquite grassland, and occasionally creosote dominated deserts (Degenhardt et al. 1996; Werler and Dixon 2000; Campbell and Lamar 1989, 2004).

In general, Crotalus molossus is a medium-sized rattlesnake with adults averaging about $100 \mathrm{~cm}$ in total length (Degenhardt et al. 1996; Campbell and Lamar 2004). Ventral scales number 164-199 in males and 168-201 in females; subcaudals range from 21-30 in males and 16-26 in females. Dorsal scale rows are usually 25 or 27 at midbody. Usually, there are 2-4 loreals, two internasals, two prefrontals, $2-3$ preoculars, five postoculars, $2-5$ intersupraoculars, 6-10 prefoveals, 13-20 supralabials and 14-21 infralabials (Klauber 1972; Degenhardt et al. 1996; Campbell and Lamar 2004). Campbell and Lamar (2004) discussed the apparent northsouth clinal variation within the species, with northern snakes tending to have a light ground color, often with grays, greens and yellows, whereas darker browns and olives commonly appear in the coloration of southern snakes. The dark brown or black rhombic dorsal blotches seem to be more variable in northern snakes, ranging from 20-43, versus 24-34 in southern populations. In nearly all cases, average scale counts for southern snakes are lower than those of northern snakes (Campbell and Lamar 2004).

This moderately sized rattlesnake reaches sexual maturity at about $70 \mathrm{~cm}$ (females). Observations of copulation are reported from late summer and fall. Ovulation occurs the following spring, and 3-16 (average of seven) live young are born in July or August. Neonate $C$. 
molossus measure 23-31 cm in length and weigh 11-28 grams (Degenhardt et al. 1996; Werler and Dixon 2000).

In the United States, the northern black-tailed rattlesnake is mostly restricted to mountainous regions within the Sonoran and Chihuahuan deserts south of the Colorado Plateau. The species ranges as far north as the Grand Canyon in Arizona, and from there its range extends south through most of Sonora, Mexico. From Sonora and Arizona, C. molossus is present through the northern Sierra Madre Occidental and the disjunct mountain ranges between the Sierra Madre and Rocky Mountains in southwestern New Mexico. In the Chihuahuan Desert its distribution follows the mountain ranges along the Rio Grande valley upstream to southern Sandoval County northwest of Albuquerque, New Mexico, and extends southeast through the Trans Pecos region of Texas. A substantial portion of the Edwards Plateau of south-central Texas is also occupied by the species (Degenhardt et al. 1996; Werler and Dixon 2000; Campbell and Lamar 2004). This south-central Texas population is apparently disjunct from the remaining population in Texas (based on range maps provided in Werler and Dixon [2000] and Campbell and Lamar [2004]). In Mexico, C. m. molossus occupies most of Sonora, northern and eastern Chihuahua and central Coahuila. There is a substantial intrusion of $C$. m. nigrescens into the northern Sierra Madre Occidental of western Chihuahua (Campbell and Lamar 2004).

The black-tailed rattlesnake is abundant throughout the southern ranges of the Rocky Mountains and the northern ranges of the Sierra Madre Occidental, but is generally absent from the lower valleys between these ranges (Degenhardt et al. 1996). The northern Chihuahuan desert is characterized by rocky mountain ranges often surpassing $2000 \mathrm{~m}$ that are separated by arid planes and basins. Here, desert scrubland communities generally occur below 1064 m, and desert grassland communities occupy elevations up to $1580 \mathrm{~m}$, with montane forests occurring at 
high elevations of north facing mountain slopes (Werler and Dixon 2000). Annual precipitation ranges from 75 millimeters $(\mathrm{mm})$ at low elevation to $400 \mathrm{~mm}$ at high elevations, with the majority of this precipitation tending to fall during the North American monsoon season (Morafka, 1977; Campbell and Lamar 2004) from late June through September, with peak precipitation in late July and August (NOAA 2004). Through much of this region, C. molossus is confined to semi-montane and montane habitats, generally occurring in rocky foothills and canyons as well as the mountains that are associated with these features (Degenhardt et al. 1996; Werler and Dixon 2000). At the northwestern border of the Chihuahuan Desert is the Cochise Filter Barrier, a narrow desert corridor that allows biotic exchange between the Sonoran and Chihuahuan ecosystems, when adequate climatic conditions persist. Approximately 4,000 years ago, this region was transformed into the desert grassland conditions that persist now. However, during the Wisconsin glacial maximum (14,000-20,000 years ago), this area experienced a vertical displacement of plant communities as great as $600 \mathrm{~m}$, allowing the contemporary mesic forest communities present at high elevations to dominate lower elevations of the area (Morafka 1977). Similar expansions of forest communities likely occurred in association with other glaciation events and may have permitted contact between eastern and western populations of $C$. molossus.

\subsection{SySTEMATICS OF THE BLACK-TAILED RATTLESNAKE}

Previous research of Crotalus molossus has focused on ecology (Beck 1995; Greene et al. 2002), physiology (Beaupre 1993) and toxinology (Chen and Real 1997), but systematics of the species has received comparatively little attention. Moreover, general phylogenetic studies of rattlesnakes have either not addressed species closely allied with C. molossus (e.g., Pook et al. 
2000; Ashton and de Queiroz 2001; Douglas et al. 2006, 2007; Castoe et al. 2007), or have focused on large-scale relationships between many taxa (e.g., Murphy et al. 2002; Castoe and Parkinson 2006).

Several hypotheses regarding the phylogenetic position of the black-tailed rattlesnake have been suggested. Gloyd (1940) recognized a group that included Crotalus basiliscus, C. durissus, C.horridus and C. molossus. A well-regarded morphological study by Klauber (1972) identified $C$. m. oaxacus as a subspecies of the Mexican west-coast rattlesnake (C. basiliscus), and placed $C$. molossus as sister to the timber rattlesnake $(C$. horridus) based on the shared presence of a vestigial left lung. Murphy et al. (2002) inferred C. basiliscus and C. molossus as sister taxa based on five mitochondrial genes. Campbell and Lamar (2004) presented a consensus phylogeny for the American pitvipers, grouping $C$. basiliscus and C. molossus in a clade with the Neotropical rattlesnakes (C.durissus, $C$. simus and C.totonacus) and C.enyo; this conclusion was largely based on the results of Murphy et al. (2002). The latest available phylogeny that includes most of the recognized members of Crotalus (Castoe and Parkinson 2006) infers a similar relationship between $C$. basiliscus, C. enyo, C. molossus and the Neotropical rattlesnakes. To date, no thorough phylogenetic study of any member of the $C$. molossus complex has been completed.

One recent contribution (Wüster et al. 2005) to the systematics of the black-tailed rattlesnake came from a review of the Neotropical rattlesnakes (Crotalus durissus and C. simus), a species complex closely related to $C$. molossus. This study incorporated several $C$. molossus samples from the three mainland subspecies. The results of the two-gene analysis recovered a weakly supported, paraphyletic $C$. molossus species complex, and moreover, the nominate subspecies (C.m. molossus) was recovered as polyphyletic with very low support (Fig. 1.6.1). A 
well-supported clade including $C$. basiliscus, $C$. totonacus and the three mainland subspecies of C. molossus were placed as sister to the Neotropical group (C. durissus and C. simus). Within this clade, C. m. nigrescens is inferred as the basal member of the C. molossus group (C. m. molossus, C. m. nigrescens, C. m. oaxacus and C. estebanensis). A subsequent divergence resulted in a $C$. totonacus/eastern $C$. m. molossus clade assigned as sister to a $C . m$. oaxacus and C. basiliscus/western C. m. molossus clade. Both phylogenies presented by Wüster et al. (2005) display similar topologies and similarly weak support between eastern and western populations of C.m. molossus, and their relationships to C. basiliscus and C. totonacus.

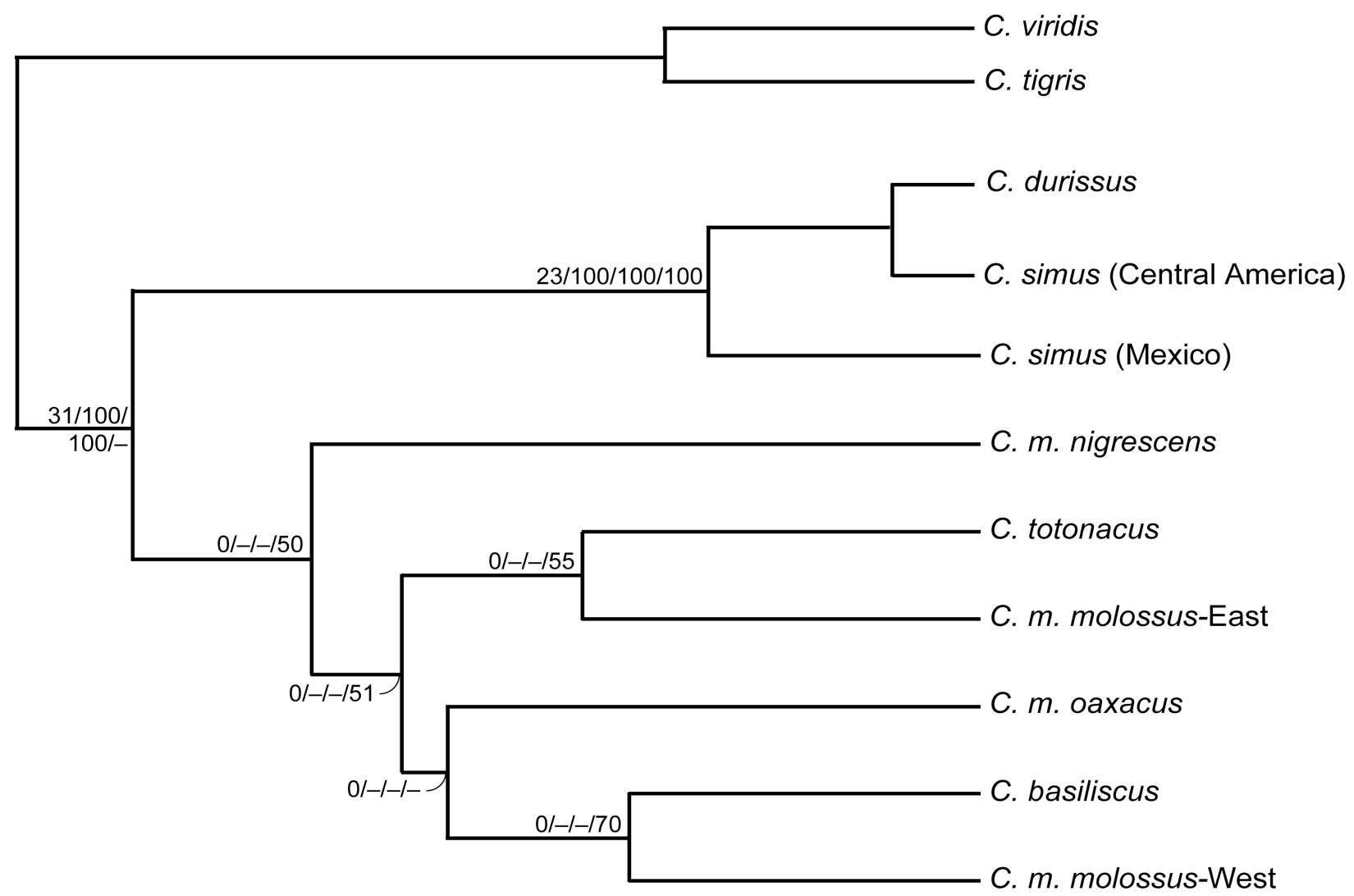

Figure 1.6.1 Phylogenetic relationships among lineages of the Crotalus molossus group, simplified from Wüster et al. (2005). Support values at nodes are Bremer support/maximum parsimony bootstrap/maximum likelihood bootstrap/Bayesian posterior probability. Dashes indicate no support. 


\subsection{RESEARCH FOCUS AND OBJECTIVES}

The discipline of phylogeography utilizes phylogenetic signals and the contemporary geographic distributions of lineages to investigate the evolutionary history of a taxon. Many components, and certainly the concepts important in phylogeography, have been present in systematic biology (in historical biogeography and later in cladistics, phylogenetics and population genetics) since its inception. However, the science of phylogeography was not formally defined until Avise et al. (1987) employed a combination of phylogenetic and population genetics methods to explain intraspecific geographic patterns presented in case studies of several taxa occurring in the southeastern United States. Phylogeographic techniques have since been applied at various taxonomic scales to infer historical population demographics, historical biogeographical patterns (i.e., vicariance and dispersal), cryptic species and conservation priorities. The use of Colubroidean snakes as models to test phylogeographic hypotheses has deepened our understanding of the respective taxa, identified hidden diversity and provided insight into the evolutionary drivers that shape the biota of ecoregions (e.g., Wüster et al. 2005; Burbrink et al. 2008; Castoe et al. 2009; Pook et al. 2009; Bryson et al. 2011).

The intent of this thesis is to build on the baseline data for Crotalus molossus provided by Wüster et al. (2005) and examine members of the C. molossus group from a phylogeographic perspective. The specific objectives of this study are to: (1) elucidate the phylogenetic relationship between the two northern $C$. molossus lineages identified by Wüster et al. (2005); (2) identify biogeographic patterns among northern populations of C. molossus; (3) determine the extent of genetic variation among populations; (4) estimate divergence dates between the major lineages in the $C$. molossus group; (5) identify discrete morphological characters; and (6) 
investigate the taxonomy of the $C$. molossus group and suggest revisions to reflect the true diversity of the group. 


\section{CHAPTER 2: MATERIALS AND MethodS}

\subsection{SPECIMEN ACQUISITION}

A total of 31 blood and tissue samples representing 21 localities throughout the range of Crotalus molossus in the United States and an additional 13 outgroup samples were obtained from the Laboratory for Environmental Biology of the University of Texas at El Paso (UTEP). The University of Texas at Arlington Department of Biology (UTA) provided samples of $C . m$ nigrescens from Durango, Mexico. Additional sequence data for C. totonacus and C. basiliscus were downloaded from GenBank and are indicated in Appendix I. Blood and tissue samples collected for this study were preserved in $95 \%$ ethanol, whereas whole specimens were preserved in $10 \%$ buffered formalin and maintained for long-term storage in $70 \%$ ethanol.

\subsection{LABORATORY PROTOCOLS}

Genomic DNA was extracted from blood and tissue samples using the Qiagen DNeasy Blood and Tissue Kit (Valencia, CA). Approximately $25 \mathrm{mg}$ of tissue was removed for extraction and placed in a $1.5 \mathrm{ml}$ microcentrifuge tube. If stored in ethanol, the samples were soaked in deionized water for 90 minutes $(\mathrm{min})$ at $0.2^{\circ} \mathrm{C}$ to allow the ethanol to diffuse out of the tissue. The samples were then allowed to dry at $0.2^{\circ} \mathrm{C}$ for at least one hour. Tissue samples were digested in a solution of $180 \mu \mathrm{l}$ of buffer ATL and $20 \mu \mathrm{l}$ of Proteinase $\mathrm{K}$ and incubated at $55^{\circ} \mathrm{C}$ for 30 min before vortexing for 10-20 seconds (s) and left to incubate overnight. Next, $200 \mu 1$ of buffer AL was added to each microcentrifuge tube. Each sample was then vortexed for 10-20 s and allowed to incubate at $70^{\circ} \mathrm{C}$ for $10 \mathrm{~min}$, after which, $200 \mu \mathrm{l}$ of $100 \%$ ethanol was added and 
the samples were vortexed again for 10-20 s. Blood samples were treated differentlyapproximately $20 \mu 1$ of $95 \%$ ethanol containing blood was transferred to a microcentrifuge tube containing $20 \mu \mathrm{l}$ of Proteinase K, $200 \mu \mathrm{l}$ of Buffer AL was added and these samples were vortexed for $10-20 \mathrm{~s}$. The samples were then incubated at $55^{\circ} \mathrm{C}$ for $10 \mathrm{~min}$ and $200 \mu 1$ of $100 \%$ ethanol was added. The entire solution containing digested blood or tissue was transferred into a Qiagen spin column and centrifuged at 8000 revolutions per minute (rpm) for $1 \mathrm{~min}$; the solution that passed through the filter of the spin column was discarded. Next, $500 \mu 1$ of Buffer AW1 was added and the samples were again centrifuged at $8000 \mathrm{rpm}$ for $1 \mathrm{~min}$. The fluid was discarded and $500 \mu 1$ of Buffer AW2 was added; samples were centrifuged at 14,000 rpm for 3 min and the fluid was discarded. Finally, $200 \mu 1$ of Buffer AE was added and samples were centrifuged at $8000 \mathrm{rpm}$ for $1 \mathrm{~min}$. This step was repeated twice and the fluid was deposited in pre-labeled microcentrifuge tubes following each repetition. The $400 \mu \mathrm{l}$ of solution retained from the final step was used for Polymerase Chain Reaction (PCR).

Three mitochondrial (mtDNA) sequences were amplified using primers specified in Table 2.2.1. Mitochondrial genes cytochrome $b$ (cyt $b$ ), NADH dehydrogenase subunit 4 (ND4) and ATP synthase subunits 8 and 6 (ATPases 8 and 6), were selected because of their utility in previous studies that investigated systematics of the Viperidae (e.g., Arévalo et al. 1994; Pook et al. 2000; Douglas et al. 2002, 2006; Pook et al. 2009). ATPases 8 and 6 exist on a contiguous mitochondrial sequence and a reading frame shift allows the 5' end of ATPase 6 to slightly overlap the 3' end of ATPase 8 (Dovc and Hecht 1995; Lovette et al. 1999; Joseph et al. 2004). Because ATPases 8 and 6 occur as a continuous sequence, they were treated as a single gene. Unlinked nuclear loci have an evolutionary history different from that of mitochondrial genes. Consequently, analysis of nDNA can recover phylogenetic patterns that are incongruent with 
mitochondrial gene trees, making nuclear loci a useful tool for identifying introgression and incomplete lineage sorting (Wiens et al. 2010). For this reason, three nuclear genes were included. The genes recombination activating protein-1 (RAG1, Wiens et al. 2008), oocyte maturation factor (c-mos, Lawson et al. 2005) and exophilin 5 (EXPH5, Portik et al. 2010, 2011) were chosen for their use in fine-scale phylogenetic analyses and potential usefulness in addressing phylogeographic relationships. Amplification was completed using a denaturation temperature of $95^{\circ} \mathrm{C}$ (initial denaturation period of $2 \mathrm{~min}$, subsequent steps were $35 \mathrm{~s}$ in duration), annealing at $50^{\circ} \mathrm{C}$ for $35 \mathrm{~s}$, and extension at $72^{\circ} \mathrm{C}$ for $95 \mathrm{~s}$ with $4 \mathrm{~s}$ added to the extension per cycle for 32 (ND4 and cyt $b$ ) and 34 cycles (nDNA genes). Amplification of ATPases 8 and 6 was accomplished in 34 cycles using similar cycle parameters, except that the annealing temperature was $46^{\circ} \mathrm{C}$ for a duration of $35 \mathrm{~s}$. Amplicons from PCR were visualized with $1.5 \%$ agarose gel electrophoresis, and samples were purified following standard protocols specified for Agencourt AMPure XP (Beckman Coulter, Brea, CA).

Table 2.2.1 List of primers used for amplification and sequencing of each fragment.

\begin{tabular}{|c|c|c|c|}
\hline Gene & Primer Name & Source & Primer Sequence (5' to 3') \\
\hline \multirow[t]{2}{*}{ ND4 } & ND4 & Arévalo et al. 1994 & CACCTATGACTACCAAAAGCTCATGTAGAAGC \\
\hline & HIS1276 & Pook et al. 2009 & TTCTATCACTTGGATTTGCACCA \\
\hline \multirow{2}{*}{ cyt $b$} & 703Bot & Pook et al. 2000 & TCAAACATCTCAACCTGATGAAA \\
\hline & MVZ16 & Pook et al. 2000 & GGCAAATAGGAAGTATCATTCTG \\
\hline ATPases & L8331 & Douglas et al. 2002 & AAAGCRTYRGCCTTTTAAGC \\
\hline \multirow[t]{2}{*}{8 and 6} & H9236 & Douglas et al. 2002 & GTTAGTGGTCAKGGGCTTGGRTC \\
\hline & 8.3 & Douglas et al. 2002 & TGATAKGCRTGTGCTTGGTG \\
\hline \multirow[t]{2}{*}{ RAG1 } & RAG1f1a & Wiens et al. 2008 & CAGCTGYAGCCARTACCATAAAAT \\
\hline & RAG1r2 & Wiens et al. 2008 & CTTTCTAGCAAAATTTCCATTCAT \\
\hline \multirow[t]{2}{*}{$\mathrm{c}-\mathrm{mos}$} & S77 & Lawson et al. 2005 & CATGGACTGGGATCAGTTATG \\
\hline & S78 & Lawson et al. 2005 & CCTTGGGTGTGATTTTCTCACCT \\
\hline \multirow[t]{2}{*}{ EXPH5 } & EXPH5 F1 & Portik et al. 2010, 2011 & AATAAACTKGCAGCTATGTACAAAACAAGTC \\
\hline & EXPH5 R1 & Portik et al. 2010, 2011 & AAYCGCCCTTCTGTGAGTGACCTCT \\
\hline
\end{tabular}


Sequencing of forward and reverse strands of PCR products was executed with an ABI 3700xl capillary DNA sequencer at the UTEP DNA Core Facility. Chromatograph data obtained from sample contigs were interpreted in the program SeqMan (Swindell and Plasterer 1997). The generally conservative nature of the genes used in this study allowed preliminary alignment to be done by eye and the program MacClade v4.08 (Maddison and Maddison 2000) was used to translate sequences to amino acids to ensure accuracy of the reading frame and to confirm that stop codons were not present in the data. GenBank accession numbers for sequence data used in this study are provided in Appendix I.

\subsection{PHYLOGENETIC INFERENCE}

Sequence data were analyzed using maximum parsimony (MP), maximum likelihood (ML) and Bayesian inference (BI) methods in PAUP* 4.0b (Swofford 2002), RAxML v7.2.6 (Stamatakis 2006) and MrBayes v3.1 (Ronquist and Huelsenbeck 2003), respectively. The MP analyses were conducted using a heuristic search algorithm with 25 random-addition replicates, accelerated character transformation and tree bisection-reconnection branch swapping. Zerolength branches were collapsed to polytomies. Node support was assessed with 1,000 nonparametric bootstrap pseudoreplicates (Felsenstein 1985). Maximum-likelihood (ML) analyses of single-gene and combined datasets were performed with the GTRGAMMA model in RAxML v7.2.6 (Stamatakis 2006). Datasets were partitioned by codon position in single gene datasets, and by gene and codon position in combined gene datasets. ML analyses were initiated with random starting trees and utilized the rapid hill-climbing algorithm (Stamatakis et al. 2007). Support for clades inferred by analyses was assessed with the rapid bootstrap algorithm with 1,000 replicates (Stamatakis et al. 2008). 
Bayesian inference (BI) was conducted in MrBayes v3.1 (Huelsenbeck and Ronquist 2001; Ronquist and Huelsenbeck 2003) for single-gene and combined datasets. Prior to BI analyses, the most appropriate evolutionary model for each codon position was inferred using the Akaike information criterion (AIC) implemented in the program jModelTest (Posada 2008). Prior to Bayesian inference, the datasets were partitioned by codon position (single gene) or by gene and codon position (combined datasets) and the evolutionary model inferred by jModelTest was specified for each partition (Brandley et al. 2005). Lemmon and Moriarty (2004) demonstrated that choosing an under parameterized substitution model could strongly bias estimations of branch length, posterior probabilities and other model specifications important for correct phylogenetic inference. Likewise, use of an over parameterized model will result in imprecise estimations of branch lengths. Therefore, when the best model suggested by jModelTest could not be implemented in MrBayes, the next most complex model was chosen. This method seems to be the best compromise for model selection, as the implementation of a model with more complex parameters seems to result in a less biased phylogenetic inference than would be obtained from a less complex model. Probability distributions were assessed with parallel Markov Chain Monte Carlo (MCMC) searches in which four Markov chains were run with default priors, a temperature of 0.05 , and initiated from randomly generated starting trees. Two MCMC searches were run for 10,000,000 generations to ensure that independent runs had converged on the same topology and trees were sampled every 1,000 generations. Are we there yet? (AWTY) (Nylander et al. 2008) was used to verify that convergence had been reached. As outlined by Brandley et al. (2011), the "cumulative" command in AWTY was implemented to construct the posterior probability plots that were examined for stationarity of split frequencies. This procedure was repeated at least four times to reduce the probability that local optima were 
influencing the results. Phylogenies inferred from BI and ML analyses were visualized in FigTree v1.3.1 (Rambaut and Drummond 2010).

\subsection{GENETIC DIVERGENCE AND MONOPHYLY TESTS}

In order to examine genetic diversity within and among lineages of the Crotalus molossus group, specimens were assigned to groups based on their position in the mtDNA phylogeny. Groups specified for analysis were restricted to geographically distinct and well-supported clades. Sequence divergence was estimated within and among these groups of C. molossus by using uncorrected pairwise $(p)$ distances calculated in MEGA v5.0 (Tamura et al. 2007). Monophyly of clades recovered in phylogenetic analyses was tested using the ShimodairaHasegawa (SH) and approximately unbiased (AU) tests implemented in CONSEL v0.1i (Shimodaira and Hasegawa 2001; Shimodaira 2002). This was accomplished by constraining the phylogeny of $C$. molossus to be monophyletic; likelihood scores were then calculated in RAxML and values from the constraint tree were evaluated against those of the preferred tree using CONSEL.

\subsection{DIVERGENCE DATING}

Divergence dates were estimated from mitochondrial datasets using a Bayesian relaxed molecular clock in the program BEAST v1.6.1 (Drummond and Rambaut 2007). This method infers divergence dates based on known node constraints (e.g., fossils, mutation rate, or the formation of a biogeographic barrier) specified prior to analysis (Drummond and Rambaut 2007), while allowing substitution rates to vary among branches (Drummond et al. 2006). 
Divergence dates were estimated with a Yule process speciation tree model, uncorrelated lognormal clock and node constraints obtained from the fossil record with lognormal distributions. Tree models were linked for analyses, but substitution and clock models remained unlinked. Preliminary analyses using site models specified for Bayesian analyses resulted in ESS values $<200$. Consequently, the model parameters $G T R+G$ and $G T R+I+G$ were specified for cyt $b$ and ND4, respectively. MCMC analyses were run four times each for 20,000,000 generations, with samples retained every 1,000 generations to ensure effective sample sizes greater than 200 in each run. The four independent runs were combined in LogCombiner v1.6.1 (Drummond and Rambaut 2007) for analysis in Tracer v1.5 (http://tree.bio.ed.ac.uk/software/tracer/) to confirm stationarity, convergence and stability of MCMC runs.

Two fossil calibrations were used, including the minimum ages of Agkistrodon contortrix and the genus Sistrurus estimated from fossil evidence presented by Holman (2000) and Parmley and Holman (2007), respectively. Sequence data for four outgroup taxa, A. contortrix, A. piscivorus, S. catenatus and S. miliarius, were obtained from Genbank for use as clock calibration references (Appendix I). Previously used calibration constraints specified by Bryson et al. (2011) were used for Agkistrodon and Sistrurus. The minimum age of A. contortrix was constrained with a zero offset of 6 mya, a lognormal mean of 0.01 and a lognormal standard deviation of 0.42 , placing its origin in the middle Hemphilian North American Land Mammal Age (NALMA). The minimum age of Sistrurus was constrained with a zero offset of 8 mya, a lognormal mean of 0.01 and a standard deviation of 0.76 , placing the age of Sistrurus at the beginning of the Clarendonian NALMA. 
Haplotype median-joining networks were constructed using the program NETWORK v4.600 (http://www.fluxus-engeneering.com; Bandelt et al. 1999). Given the high degree of divergence and strong support for clades, separate haplotype networks were constructed for the eastern and western $C$. m. molossus lineages with the mtDNA dataset (weights $=10$ and $\varepsilon=0$ ). Genetic diversity within and among geographical clades recovered by phylogenetic inferences was calculated for the mtDNA dataset and individual nDNA genes in ARLEQUIN v3.5 (Excoffier and Lischer 2010). In addition, ARLEQUIN was used to conduct a hierarchical analysis of molecular variance (AMOVA, Excoffier et al. 1992). AMOVA was used to infer the most probable configuration of geographical clades by analyzing various combinations of 2-7 groups that corresponded to the geographical hierarchy recovered in phylogenetic analyses. The most parsimonious combinations of geographical clades were those that maximized variation among groups $\left(\mathrm{F}_{\mathrm{CT}}\right)$ and were statistically significant (Zhang et al. 2010). Population expansion was assessed in ARLEQUIN with Fu's $F$ s and Tajima's $D$ tests of neutrality (Fu 1997) and mismatch distributions estimates (for clades with adequate sampling). Mismatch distributions test for sudden population expansions based on a raggedness index calculated for observed data points around a simulated curve. Rogers and Harpending (1992) demonstrated that under an infinite sites model, the mismatch distribution exhibited by populations that have undergone recent expansion will be smooth or unimodal, whereas populations that are stable will exhibit a ragged or multimodal distribution (Harpending 1994; Harpending et al. 1998). 


\subsection{MORPHOLOGICAL ANALYSIS}

The morphological assessment consisted of six C. totonacus, two C. basiliscus and 103 specimens from the Crotalus molossus group (99 C. molossus, and type material of C. molossus, C. ornatus, C.m. oaxacus and C.m.estebanensis) representing populations from throughout the known geographic range of Crotalus molossus. Localities and collection data for examined specimens are presented in Appendix II. Each specimen was assigned to one of five lineages (eastern C.m.molossus, western C.m.molossus, C.m.nigrescens, C. basiliscus or C.totonacus) based on results inferred from phylogenetic analyses, collection data associated with the specimen (e.g., locality and preliminary identification by the collector) and diagnostic characters for previously recognized taxa in the C. molossus group (Gloyd 1936, 1948; Klauber 1948, 1972).

Characters examined herein were chosen from previous morphological investigations of Colubroidean snakes (Devitt et al. 2008; LaDuc and Johnson 2003), and were identified as either highly variable in the C. molossus group (Klauber 1972; Campbell and Lamar 1989, 2004), or used in the diagnosis of C.m. nigrescens by Gloyd (1948). All mensural data were collected with a digital caliper under a dissecting microscope and rounded to the nearest $0.1 \mathrm{~mm}$. Snoutvent (SVL) and tail length (TL) were measured with a metric ruler and rounded to the nearest 1.0 mm. The type specimens of $C$. molossus and $C$. ornatus are preserved as skins with the head and tail attached. Consequently, SVL was estimated based on ratios of head length to SVL and TL to SVL for these specimens. Because of damage to some specimens (including type material), it was not possible to collect a complete dataset for some individuals. Therefore, mensural, meristic and qualitative characters were assessed on the right side of the head only. 
Data recorded from each specimen included 21 mensural, 16 meristic and two qualitative characters: SVL; TL; head length (HL); head width (HW) - measured at the widest point of the head; naso-ocular distance (NOD); interocular distance (ID); internasal distance (INAS); rostral scale height $(\mathrm{RH})$; rostral scale width (RW); mental scale height $(\mathrm{MH})$; mental scale width (MW); chin shield length (CSL); chin shield width (CSW); upper preocular scale height (UPH); upper preocular scale length (UPL); lower preocular scale height (LPH); lower preocular scale length (LPL); prefrontal scale length (PFL); prefrontal scale width (PFW); supraocular scale length (SOCL); supraocular scale width (SOCW). Meristic data included: number of ventral scales (VENT) - following the method proposed by Dowling (1951); subcaudals (SCDL); internasals (INAS); prefrontals (PFRO); loreals (LOR); intersupraoculars (ISO) - assessed as the fewest number of scales between supraoculars posterior to the frontals; supralabials (SUPRA); infralabials (INFRA); foveals (FOV)-lacunals; subfoveals (SFOV); prefoveals (PFOV); number of dorsal blotches (DBLOT); number of fused dorsal blotches (FDBLOT)-counted as the number of dorsal blotches connected by at least one scale row; dorsal scale rows counted at the neck, midbody and one head length anterior to the vent (DSRN, DSRM and DSRV, respectively). Qualitative characters were postrostral scale (POSTROST)-presence or absence, and contact (present or absent) between the prenasal and first supralabial (PRE-SUP).

Mean, standard deviation and range of meristic and mensural characters were calculated for each group, and a pairwise comparison of means (ANOVA) was conducted. To eliminate the effect of size, an analysis of covariance (ANCOVA) with snout-vent length as the covariate was conducted on the mensural dataset. Principal components analyses (PCA), conducted in Minitab 17 (Minitab ${ }^{\circledR}$ Statistical Software, State College, PA), were used to identify patterns of variation in the data that may be useful in assigning specimens to the geographical lineages identified in 
phylogenetic analyses. All analyses used the covariance matrix. To eliminate the effects of sexual dimorphism and size on mensural characters, PC analyses were conducted separately on adult male and female datasets using the residuals obtained from the ANCOVA. The meristic dataset was assessed with PC analyses of raw data. Sexually dimorphic characters (VENT and SCDL) did not influence the delineation of taxonomic groups, and the meristic dataset was not partitioned by sex. 


\section{CHAPTER 3: RESULTS}

\subsection{PhyLOGENETIC ANALYSIS}

A total of three mtDNA genes (ND4 $=678$ base pairs [bp]; cyt $b=728 \mathrm{bp}$; ATPases 8 and $6=637 \mathrm{bp}$ ) were analyzed for 31 samples of Crotalus molossus. Because some samples were degraded, only 23 C. molossus samples were amplified for three nDNA genes $(\mathrm{RAG} 1=$ $926 \mathrm{bp} ; \mathrm{c}-\mathrm{mos}=570 \mathrm{bp}$; EXPH5 = $770 \mathrm{bp}$ ). Samples of C. . nigrescens failed to amplify for all nDNA genes and only sequences of cyt $b$ and ND4 for $C$. totonacus and $C$. basiliscus were available from GenBank. In spite of the large amount of missing data, these taxa were included in analyses of the six-gene dataset (ND4; cyt $b$; ATPases 8 and 6; RAG1; c-mos; EXPH5). Although this may be cause for concern, the placement of taxa that are missing a significant portion of sequence data can be accurately inferred in a phylogeny, given an adequate number of informative characters (Wiens 2003; Pyron et al. 2011).

Nucleotide substitution models selected by jModelTest and alternative models implemented in BI analyses are presented in Table 3.1.1. The topologies of trees generated from MP, ML and BI analyses of individual mtDNA genes were mostly congruent. The only discrepancies were between weakly supported nodes and some rearrangements of the outgroup taxa in MP analyses. However, analyses of single nuclear genes recovered extensive incongruence among gene trees. Trees recovered from separate nDNA analyses were examined in detail, on a node-by-node basis; this revealed low support for incongruent nodes among phylogenies. This suggested that the incongruence among gene trees was weak and that combining these datasets, which reflect slightly different evolutionary histories, may result in a more accurate phylogenetic estimation (Wiens 1998). Consequently, various combinations of 
the data were analyzed (mtDNA dataset [ND4; cyt b; ATPases 8 and 6], a nDNA dataset [c-mos; EXPH5; RAG1] and a combined six-gene dataset).

Table 3.1.1 Model parameters specified by jModelTest and alternative models implemented in Bayesian inference analyses.

\begin{tabular}{cll}
\hline $\begin{array}{c}\text { Gene } \\
\text { Codon Position }\end{array}$ & $\begin{array}{c}\text { Model Specified } \\
\text { by jodelTest }\end{array}$ & $\begin{array}{c}\text { Model Implemented } \\
\text { in MrBayes }\end{array}$ \\
\hline $\begin{array}{c}\text { ATPas 8 and 6 } \\
\text { Codon 2 }\end{array}$ & HKY+G & TIM2+I+G \\
Codon 3 & TPM3uf+I+G & HKY+I+G \\
TPM1uf+I+G & HKY+I+G \\
cyt $\boldsymbol{b}$ & TIM2+G $+\mathrm{I}+\mathrm{G}$ \\
Codon 1 & TIM2ef+I+G & K80+I+G \\
Codon 2 & TIM1+I+G & GTR+I \\
Codon 3 & HKY+I & HKY+I \\
\hline ND4 & TIM3+I+G & \\
Codon 1 & GTR+I+G & GTR+I+G \\
Codon 2 & TPM2uf+I & HKY+I \\
Codon 3 & TVM3ef+I+G & HKY+G \\
\hline c-mos & GTR+I+G & \\
Codon 1 & HKY & HKY \\
Codon 2 & TVM+G & GTR+G \\
Codon 3 & TrN+I & HKY+I \\
\hline EXPH5 & TPM1uf+I+G & \\
Codon 1 & TIM1+I & GTR+I \\
Codon 2 & TrN+I & HKY+I \\
Codon 3 & K80+I+G & K80+I+G \\
\hline RAG1 & TPM1uf+I+G & F81 \\
Codon 1 & F81 & F81 \\
Codon 3 & F81 & TPM3uf+I $+\mathrm{I}$ \\
\hline & &
\end{tabular}

The MP analysis of the mtDNA dataset recovered six most parsimonious trees with 1,864 steps (774 variable sites, 591 parsimony-informative sites, consistency index [CI] of 0.518 and a 
retention index $[\mathrm{RI}]$ of 0.761$)$. Parsimony analysis of the six-gene dataset found four most parsimonious trees with 1,580 steps (518 of the 759 variable sites were informative, $\mathrm{CI}=0.585$ and $\mathrm{RI}=0.760$ ). Tree topologies presented for the mtDNA and six-gene datasets (Figs. 3.1.1 and 3.1.2, respectively) are the best scoring trees found by RAxML $(-\ln L=-10756.53$ and $-\ln L$ $=-12699.08$, respectively). Posterior probability plots constructed with AWTY indicated that convergence of Bayesian MCMC searches was reached relatively quickly in all analyses ( $20 \%$ of generations), so a conservative $25 \%$ of sampled generations were discarded and posterior probabilities were estimated from the remaining post burn-in trees.

In the mtDNA and six-gene datasets (Figs. 3.1.1 and 3.1.2, respectively), Crotalus molossus nigrescens was recovered at the base of a well-supported, monophyletic clade including $C$. basiliscus, C. totonacus and C. m. molossus. However, the latter taxon was recovered as paraphyletic with deeply divergent eastern and western C. molossus lineages, with strong support from both the mtDNA and six-gene datasets. The geographic distribution of clades within the divergent eastern and western C.m. molossus lineages is presented in Figure 3.1.3. Within the western lineage, the Madrean clade is inferred with strong support, and is geographically restricted to the northern extensions of the Sierra Madre Occidental, the Madrean Archipelago, and southern terminal ranges of the Rocky Mountains in southwestern New Mexico and southeastern Arizona. A second well-supported group within the western C. m. molossus lineage (the Sonoran clade) was recovered from populations in west-central Arizona. In the eastern $C . m$. molossus lineage, a well-supported basal divergence separates a clade in the western Chihuahuan Desert (the Chihuahuan clade) from two closely related clades occurring in the Big Bend region and the Stockton and Edwards plateaus (Big Bend and Stockton clades, 


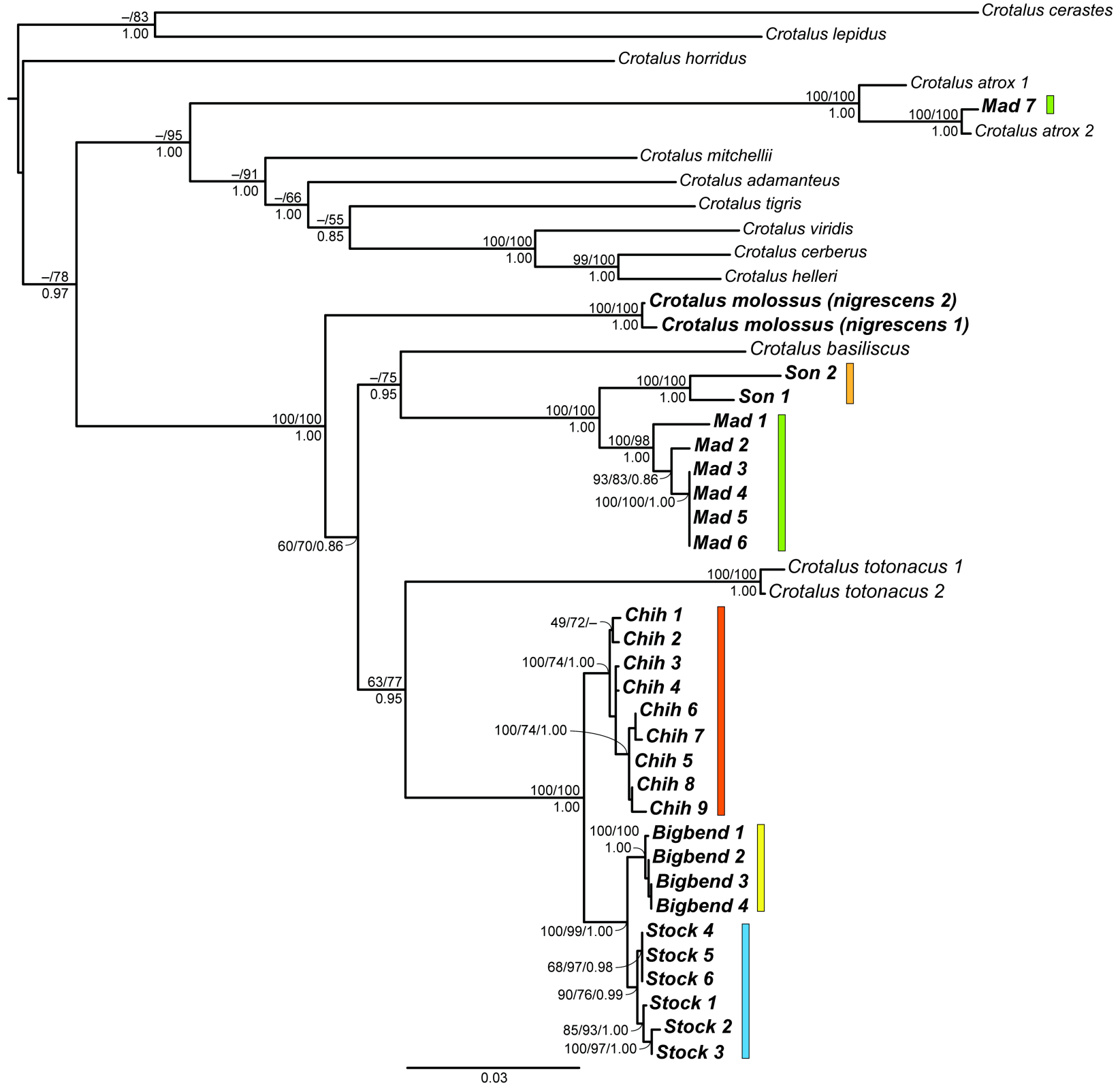

Figure 3.1.1 Phylogeny inferred from the combined mtDNA dataset (ATPases 8 and 6, cyt $b$ and ND4); node labels are MP bootstrap/ML bootstrap/Bayesian posterior probability. Samples representing the currently recognized Crotalus molossus group are in bold text. Colored bars and abbreviations correspond to five geographically defined clades: Sonoran (Son), Madrean (Mad), Chihuahuan (Chih), Big Bend (Bigbend) and Stockton (Stock). 


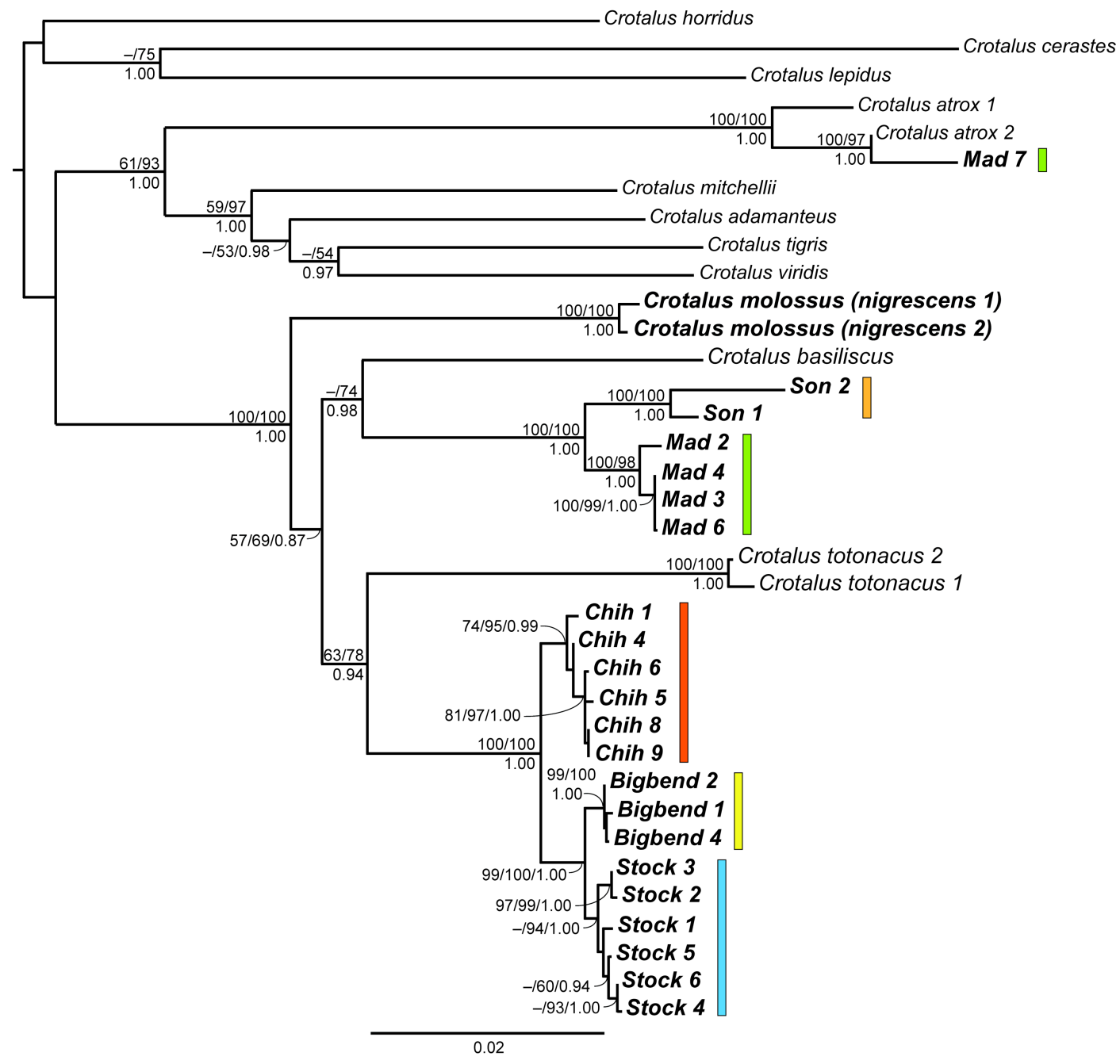

Figure 3.1.2 Phylogeny inferred from the six-gene dataset (ATPases 8 and 6, cyt $b$, ND4, c-mos, EXPH5 and RAG1); node labels are MP bootstrap/ML bootstrap/Bayesian posterior probability. Samples representing the currently recognized Crotalus molossus group are in bold text. Colored bars and abbreviations correspond to five geographically defined clades: Sonoran (Son), Madrean (Mad), Chihuahuan (Chih), Big Bend (Bigbend) and Stockton (Stock). 


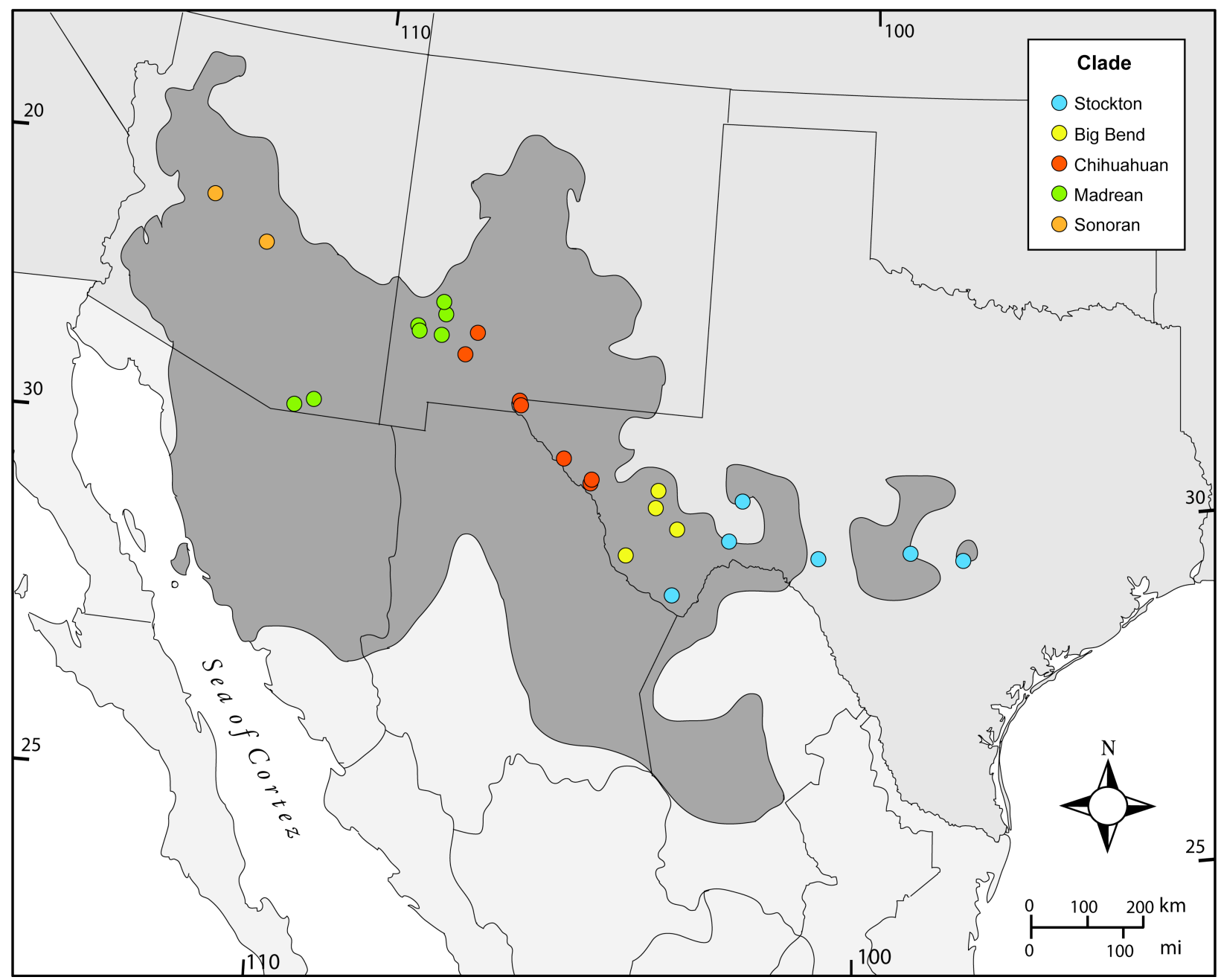

Figure 3.1.3 Sampling localities and geographically defined clades recovered in haplotype and phylogenetic analyses of Crotalus molossus. Gray shading depicts the general distribution of $C$. m. molossus; modified from a map by Campbell and Lamar (2004). 

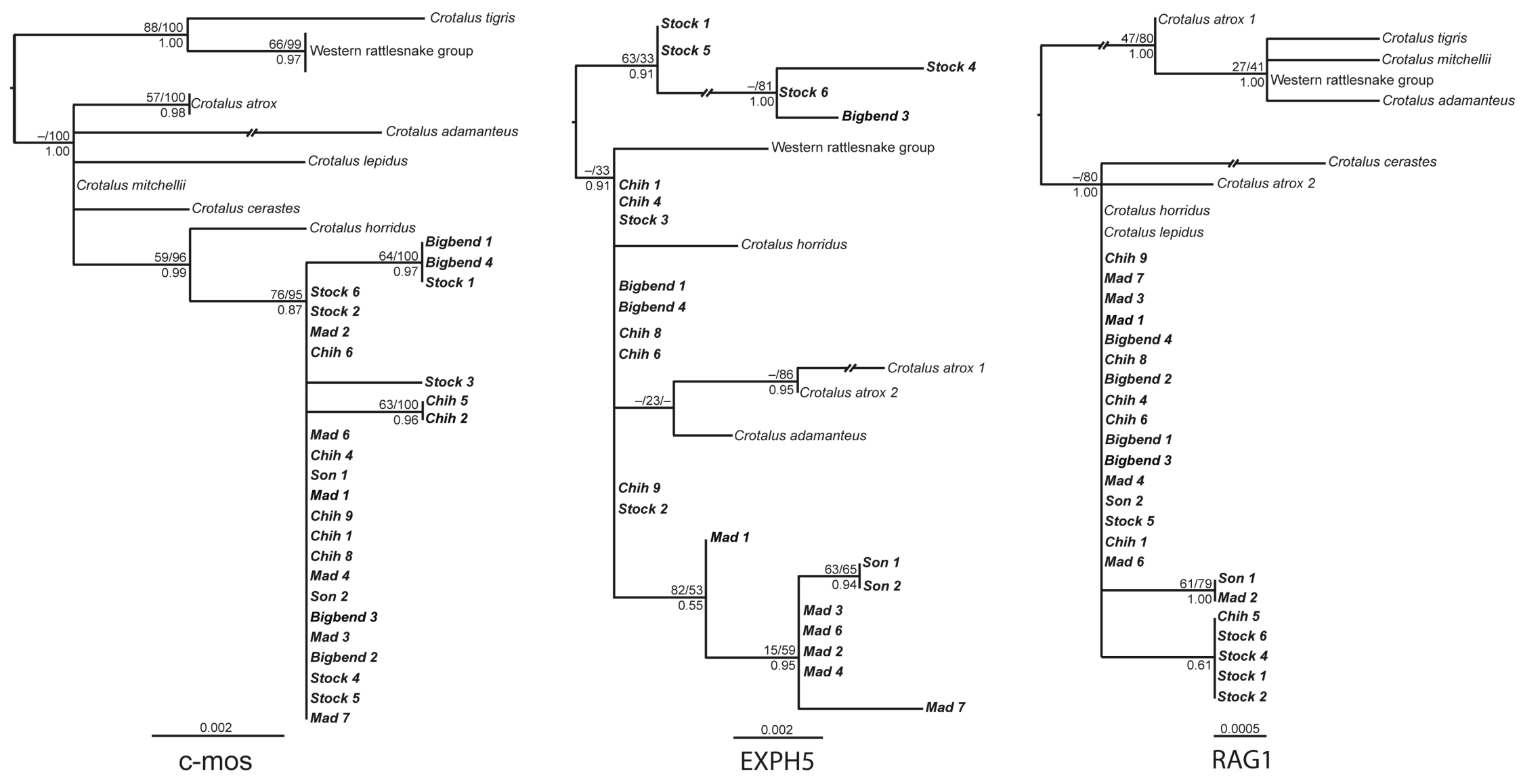

Figure 3.1.4 Phylogenetic trees inferred from single nDNA datasets for c-mos, EXPH5 and RAG1. Samples representing the currently recognized Crotalus molossus group are in bold text. Abbreviations correspond to five geographically defined clades recovered within C. m. molossus: Sonoran (Son), Madrean (Mad), Chihuahuan (Chih), Big Bend (Bigbend) and Stockton (Stock). The western rattlesnake group refers to C. cerberus, C. oreganus and C. viridis. 
respectively). Strongly supported sister relationships between $C$. totonacus and the eastern $C$. molossus lineage, and C. basiliscus and the western C.m. molossus lineage were recovered in BI analyses, but MP and ML analyses recovered weak to moderate support for these sister relationships $(<78 \%)$.

Single-gene analyses of nDNA datasets resulted in greatly dissimilar topologies among gene trees (Fig. 3.1.4). No single nuclear gene was able to provide resolution among populations of Crotalus molossus. Inference of the c-mos gene recovered eastern and western C. $m$. molossus lineages in a monophyletic group that is sister to $C$. horridus. Although a monophyletic western C.m. molossus lineage was recovered in analyses of EXPH5, its position was ambiguous with respect to outgroup taxa. In the absence of $C$. basiliscus and $C$. totonacus, analysis of the combined nDNA dataset (not shown) recovered a monophyletic C. molossus with weak MP and ML support and moderate Bayesian posterior probability support (23\% MP, $64 \%$ ML, $0.94 \mathrm{BI}$ ), and the position of a monophyletic western lineage of $C . m$. molossus was unresolved. Despite the lack of resolution in the combined nDNA dataset, results of the mtDNA and six-gene datasets are nearly identical, which may be the result of bias caused by the more rapidly evolving and hence more variable mitochondrial genes (Wiens et al. 2010).

\subsection{GENETIC DIVERGENCE AND HYPOTHESIS TESTS}

In order to examine genetic diversity among populations of Crotalus molossus, specimens were assigned to groups based on well-supported, geographically distinct clades indicated in Figures 3.1.1 and 3.1.2. Uncorrected p-distances (Table 3.2.1) within and among clades of $C$. molossus are provided for the mtDNA dataset. The greatest divergence among lineages in the $C$. molossus group was between $C . m$. nigrescens and the Sonoran clade (9.2\%). 
Distances ranging from 7.6-7.9\% were observed between eastern and western C. m. molossus lineages. Divergence between the western lineage and C. basiliscus ranged from 7.3-8.1\%, and a genetic divergence of $7.1-7.2 \%$ was recovered between $C$. totonacus and the eastern lineage. Among clades within the eastern lineage, divergences ranged from $0.5 \%$ between the Big Bend and Stockton clades to $1.2 \%$ between the Bigbend/Stockton and Chihuahuan clades. Divergence between the Sonoran and Madrean clades of the western lineage was 3.6\%.

All analyses of the mtDNA and six-gene datasets recovered a paraphyletic Crotalus $m$. molossus. In hypothesis tests, monophyly of this taxon was rejected for both the mtDNA (AU $P$ $=0.0004 ;$ SH $P=0)$ and six-gene (AU $P=0.00005$; SH $P=0)$ datasets.

Table 3.2.1 Uncorrected $p$-distances within and among groups of Crotalus molossus, which are calculated from the combined mtDNA dataset. Six lineages within the $C$. molossus group (the Chihuahuan clade [Chi], the Big Bend clade [BB], the Stockton clade [Stock], the Madrean clade [Mad], the Sonoran clade [Son.], C. m. nigrescens [Cmn]), C. basiliscus (Cbas) and C. totonacus (Ctot) were examined.

\begin{tabular}{|l|l|l|l|l|l|l|l|l|}
\hline & Chi. & BB & Stock & Mad & Son & Cmn & Cbas & Ctot \\
\hline Chi. & $\mathbf{0 . 0 0 3}$ & & & & & & & \\
\hline BB & 0.012 & $\mathbf{0 . 0 0 2}$ & & & & & & \\
\hline Stock & 0.012 & 0.005 & $\mathbf{0 . 0 0 2}$ & & & & & \\
\hline Mad & 0.076 & 0.077 & 0.076 & $\mathbf{0 . 0 0 7}$ & & & & \\
\hline Son & 0.079 & 0.078 & 0.079 & 0.036 & $\mathbf{0 . 0 2 2}$ & & & \\
\hline Cmn & 0.078 & 0.081 & 0.080 & 0.085 & 0.092 & $\mathbf{0 . 0 0 2}$ & & \\
\hline Cbas & 0.078 & 0.077 & 0.075 & 0.073 & 0.081 & 0.086 & NA & \\
\hline Ctot & 0.072 & 0.071 & 0.071 & 0.085 & 0.085 & 0.090 & 0.081 & $\mathbf{0 . 0 0 3}$ \\
\hline
\end{tabular}

\subsection{Population and geographic structure analysis}

Estimates of genetic diversity and neutrality tests within populations are presented in Table 3.3.1. The haplotype diversity $(h=1.0)$ and nucleotide diversity $(\pi=0.0516)$ among all 
individuals of $C$. basiliscus, C. totonacus and all populations of $C$. molossus suggests that very little gene flow occurred between populations, and that the geographically defined clades identified herein likely evolved in allopatry. In the AMOVA (Table 3.3.2), the greatest genetic variance among groups $\left(\mathrm{F}_{\mathrm{CT}}=0.860, P<0.05\right)$ was found with seven groups ([nigrescens] [basiliscus] [Madrean] [Sonoran] [totonacus] [Chihuahuan] [Bigbend, Stockton]). This is congruent with the well-supported clades recovered in the phylogenetic analyses (Figs. 3.1.1 and 3.1.2).

Table 3.3.1 Genetic diversity estimates and neutrality tests within populations of Crotalus basiliscus, $C$. totonacus and the $C$. molossus group. $\mathrm{n}=$ sample size; $\pi=$ nucleotide diversity; $h$ $=$ haplotype diversity; $\kappa=$ mean number of pairwise differences.

\begin{tabular}{|c|c|c|c|c|c|c|c|c|}
\hline Clade & $\mathbf{n}$ & $\boldsymbol{\pi}$ & $\boldsymbol{h}$ & $\boldsymbol{\kappa}$ & $\mathbf{F u} \mathbf{s} \boldsymbol{F} \mathbf{S}$ & $\begin{array}{c}\boldsymbol{P} \text { - } \\
\text { value }\end{array}$ & $\begin{array}{c}\text { Tajima's } \\
\boldsymbol{D}\end{array}$ & $\begin{array}{c}\boldsymbol{P} \text { - } \\
\text { value }\end{array}$ \\
\hline Chihuahuan & 9 & 0.0031 & 1.0 & 5.53 & -4.535 & 0.004 & -0.296 & 0.417 \\
\hline Big Bend & 4 & 0.0008 & 1.0 & 1.67 & -2.181 & 0.018 & 0.168 & 0.741 \\
\hline Stockton & 6 & 0.0026 & 1.0 & 5.33 & -2.035 & 0.058 & 0.648 & 0.762 \\
\hline Madrean & 6 & 0.0062 & 1.0 & 12.20 & -0.661 & 0.216 & -0.990 & 0.196 \\
\hline Sonoran & 2 & 0.0211 & 1.0 & 43.00 & 3.761 & 0.599 & - & - \\
\hline nigrescens & 2 & 0.0029 & 1.0 & 6.00 & 1.792 & 0.511 & - & - \\
\hline totonacus & 2 & 0.0045 & 1.0 & 6.00 & -0.661 & 0.216 & - & - \\
\hline basiliscus & 1 & - & - & - & - & - & - & - \\
\hline Total & $\mathbf{3 2}$ & $\mathbf{0 . 0 5 1 6}$ & $\mathbf{1 . 0}$ & $\mathbf{6 8 . 8 0}$ & $\mathbf{- 6 . 3 0 6}$ & $\mathbf{0 . 0 1 5}$ & $\mathbf{0 . 1 7 5}$ & $\mathbf{0 . 6 4 8}$ \\
\hline
\end{tabular}


Table 3.3.2 Hierarchical analysis of molecular variance among lineages in the Crotalus molossus group. $(* P<0.05 ; * * P<0.01 ; * * * P<0.001)$

\begin{tabular}{|c|c|c|c|c|c|}
\hline Groups & $\mathrm{F}_{\mathrm{ST}}$ & $\mathrm{F}_{\mathrm{SC}}$ & $\mathrm{F}_{\mathrm{CT}}$ & $\begin{array}{c}\% \text { among } \\
\text { populations }\end{array}$ & $\begin{array}{c}\% \text { within } \\
\text { populations }\end{array}$ \\
\hline All populations & 0.923 & - & - & 92.30 & 7.70 \\
\hline $\begin{array}{l}2 \text { Groups [nigrescens] [basiliscus, } \\
\text { totonacus, Chihuahuan, Bigbend, } \\
\text { Stockton, Madrean, Sonoran] }\end{array}$ & $0.945 * * *$ & $0.917 * * *$ & 0.336 & 33.59 & 5.48 \\
\hline $\begin{array}{l}2 \text { Groups [nigrescens, totonacus, } \\
\text { Chihuahuan, Bigbend, Stockton, } \\
\text { Madrean, Sonoran] [basiliscus] }\end{array}$ & $0.941 * * *$ & $0.921 * * *$ & 0.250 & 25.01 & 5.92 \\
\hline $\begin{array}{l}2 \text { Groups [nigrescens, basiliscus, } \\
\text { Chihuahuan, Bigbend, Stockton, } \\
\text { Madrean, Sonoran] [totonacus] }\end{array}$ & $0.942 * * *$ & $0.919 * * *$ & 0.281 & 28.06 & 5.85 \\
\hline $\begin{array}{l}3 \text { Groups [nigrescens] [Madrean, } \\
\text { Sonoran, basiliscus] [totonacus, } \\
\text { Chihuahuan, Bigbend, Stockton] }\end{array}$ & $0.941 * * *$ & $0.861 * * *$ & $0.578 * * *$ & 57.81 & 5.88 \\
\hline $\begin{array}{l}3 \text { Groups [nigrescens] [Madrean, } \\
\text { Sonoran, basiliscus, totonacus] } \\
\text { [Chihuahuan, Bigbend, Stockton] }\end{array}$ & $0.939 * * *$ & $0.855 * * *$ & $0.581 * *$ & 58.06 & 6.09 \\
\hline $\begin{array}{l}3 \text { Groups [nigrescens, basiliscus] } \\
\text { [Madrean, Sonoran, totonacus] } \\
\text { [Chihuahuan, Bigbend, Stockton] }\end{array}$ & $0.938 * * *$ & $0.857 * * *$ & $0.564 *$ & 56.42 & 6.21 \\
\hline $\begin{array}{c}3 \text { Groups [nigrescens, basiliscus, } \\
\text { totonacus] [Madrean, Sonoran] } \\
\text { [Chihuahuan, Bigbend, Stockton] }\end{array}$ & $0.937 * * *$ & $0.842 * * *$ & $0.606 * *$ & 60.62 & 6.22 \\
\hline $\begin{array}{c}\text { Groups [nigrescens] [basiliscus] } \\
\text { [Madrean, Sonoran] [totonacus, } \\
\text { Chihuahuan, Bigbend, Stockton] }\end{array}$ & $0.942 * * *$ & $0.841 * * *$ & $0.637 * *$ & 63.67 & 5.79 \\
\hline $\begin{array}{c}4 \text { Groups [nigrescens] [basiliscus, } \\
\text { Madrean, Sonoran] [totonacus] } \\
\text { [Chihuahuan, Bigbend, Stockton] }\end{array}$ & $0.941 * * *$ & $0.794 * * *$ & $0.711 * *$ & 71.11 & 5.96 \\
\hline $\begin{array}{c}4 \text { Groups [nigrescens] [basiliscus, } \\
\text { totonacus] [Madrean, Sonoran] } \\
\text { [Chihuahuan, Bigbend, Stockton] }\end{array}$ & $0.940 * * *$ & $0.789 * * *$ & $0.714 * * *$ & 71.44 & 6.03 \\
\hline $\begin{array}{c}5 \text { Groups [nigrescens] [basiliscus] } \\
\text { [totonacus] [Madrean, Sonoran] } \\
\text { [Chihuahuan, Bigbend, Stockton] }\end{array}$ & $0.941 * * *$ & $0.721 * * *$ & $0.790 * *$ & 78.96 & 5.88 \\
\hline $\begin{array}{c}5 \text { Groups [nigrescens] [basiliscus, } \\
\text { Madrean, Sonoran] [totonacus] } \\
\text { [Chihuahuan] [Bigbend, Stockton] }\end{array}$ & $0.928 * * *$ & $0.830 * * *$ & $0.573^{*}$ & 57.34 & 7.24 \\
\hline $\begin{array}{c}6 \text { Groups [nigrescens] [basiliscus] } \\
\text { [Madrean, Sonoran] [totonacus] } \\
\text { [Chihuahuan] [Bigbend, Stockton] }\end{array}$ & $0.928 * * *$ & $0.725 * * *$ & $0.737 * *$ & 73.72 & 7.22 \\
\hline $\begin{array}{c}\text { 6 Groups [nigrescens] [basiliscus] } \\
\text { [Madrean] [Sonoran] [totonacus] } \\
\text { [Chihuahuan, Bigbend, Stockton] }\end{array}$ & $0.940 * * *$ & $0.652 * * *$ & $0.828^{*}$ & 82.85 & 5.97 \\
\hline $\begin{array}{c}7 \text { Groups [nigrescens] [basiliscus] } \\
\text { [Madrean] [Sonoran] [totonacus] } \\
\text { [Chihuahuan] [Bigbend, Stockton] }\end{array}$ & $0.927 * * *$ & $0.478 * * *$ & $0.860 *$ & 85.89 & 7.32 \\
\hline
\end{tabular}


Mismatch distributions were generated from well-sampled clades with the mtDNA dataset including the Madrean clade (western lineage) and the three clades from the eastern lineage. Mismatch distributions were also generated with c-mos, EXPH5 and RAG1 datasets for clades that had sufficient sample sizes (Fig. 3.3.1). The mtDNA dataset recovered multimodal distributions and non-significant raggedness indices for all four clades, indicating that the populations are stable or slowly declining (Rogers and Harpending 1992). Non-significant Fu's $F$ s tests $(P>0.02)$ (Table 3.3.1) for the Madrean, Sonoran and Stockton clades also support a hypothesis of selective neutrality and population stability. However, the significant Fu's $F s$ tests recovered from the Chihuahuan and Big Bend clades $(P=0.004$ and 0.018 , respectively) suggest recent demographic expansion. This is also reflected in the lower (although not significant) raggedness indices recovered for these groups.

Haplotype networks constructed for the eastern and western C. m. molossus lineages (Fig. 3.3.2) identified geographic variation within and among clades. In the eastern lineage, the three clades identified in phylogenetic analyses (Chihuahuan, Bigbend and Stockton) are separated by 25 and 11 mutations, respectively. One sample in the Chihuahuan clade (Chih 2) is separated from the remaining group by 101 mutations, but this result is a consequence of missing data. Two additional samples (Chih 6 and Chih 7) are separated from the remaining clade members by 79 mutations. These two samples, taken from Luna and Sierra Counties in New Mexico, may represent another geographically distinct clade. However, phylogenetic inferences did not indicate marked divergence from the Chihuahuan clade. The western lineage is separated from the eastern by 142 mutations. Within the western lineage, the Sonoran and Madrean clades are separated by 49 mutations. In some cases, the large number of mutations observed between 

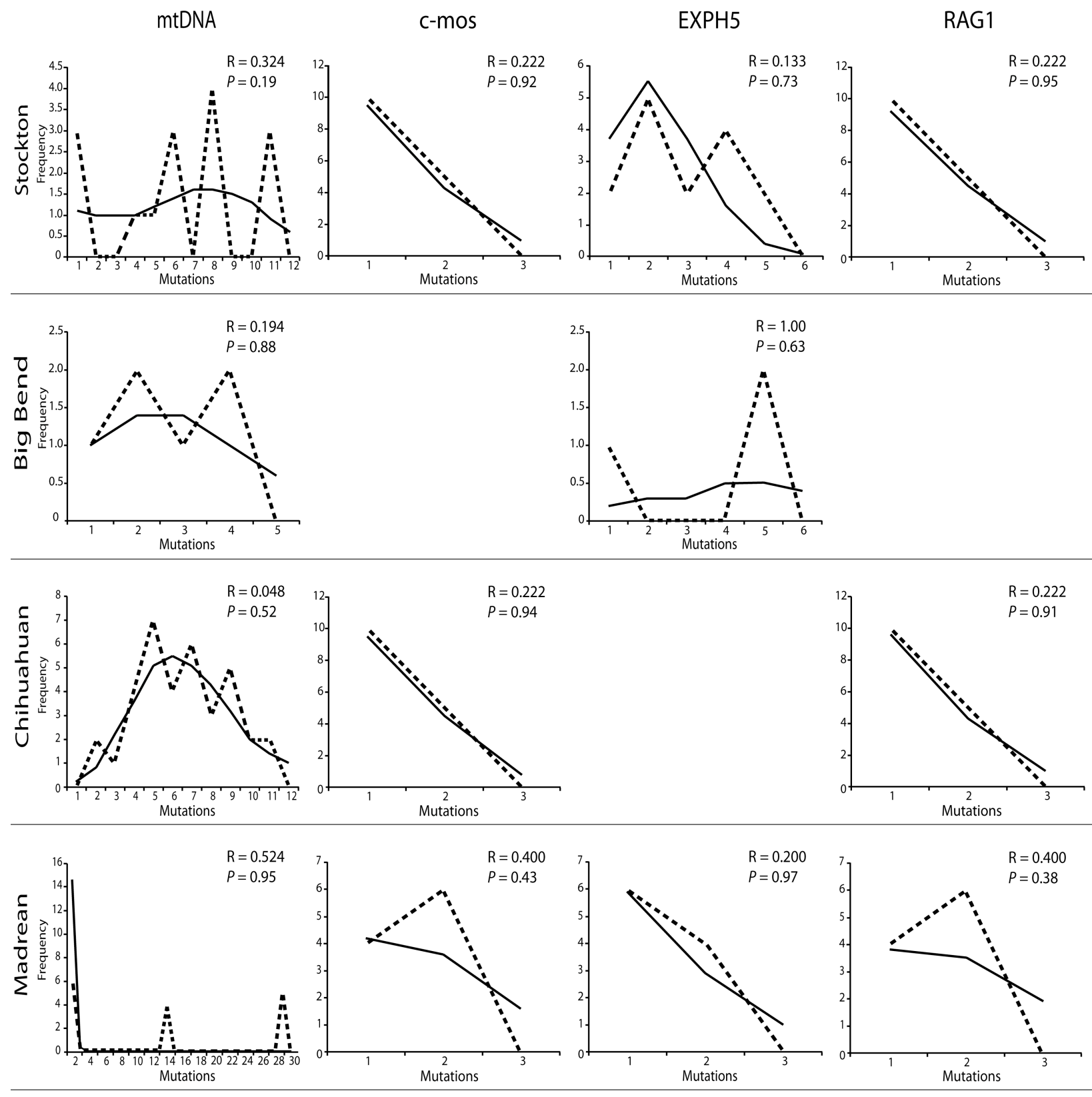

Figure 3.3.1 Mismatch distributions computed from mitochondrial (ATPases 8 and 6 , cyt $b$, and ND4), c-mos, EXPH5 and RAG1 datasets for the well-sampled Chihuahuan, Big Bend, Stockton and Madrean clades. Sample sizes were not large enough to calculate mismatch distributions for the Big Bend clade (c-mos and RAG1) or Chihuahuan clade (EXPH5). Dashed lines indicate the observed distribution of pairwise differences and solid lines illustrate the expected distribution. 


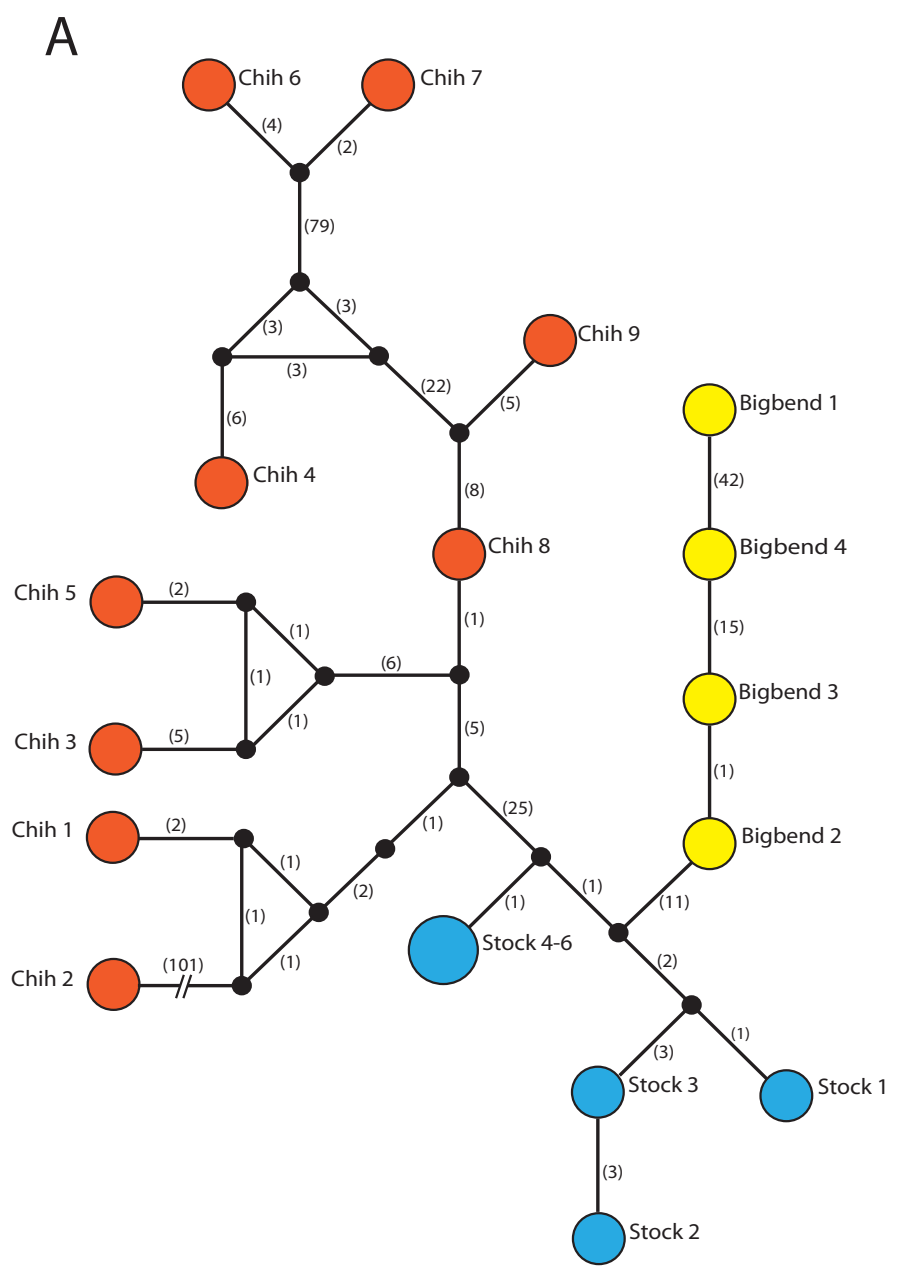

B

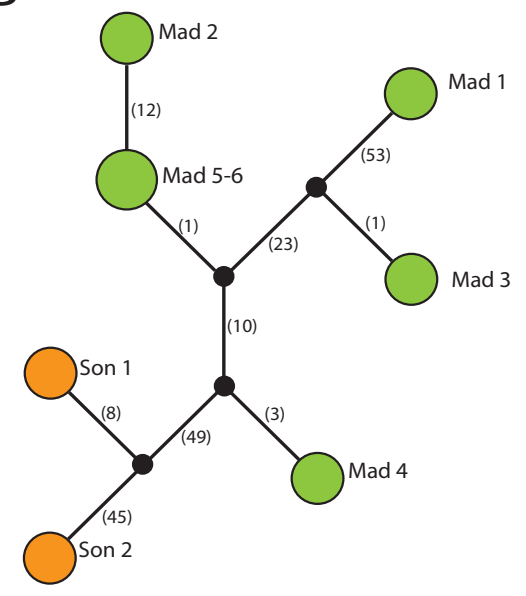

Figure 3.3.2 Haplotype networks for eastern (A) and western (B) lineages of Crotalus $m$. molossus, calculated from the mitochondrial dataset (ATPases 8 and 6, cyt $b$ and ND4) in the program Network. 
haplotypes within well-supported lineages is not evident in phylogenetic inferences and seems to correspond to missing sequence data (e.g., Bigbend 1, Chih 2, 6 and 7).

\subsection{DivergenCe DATing}

A mitochondrial dataset consisting of cyt $b$ and ND4 was used to estimate divergence dates in BEAST; data from ATPases 8 and 6 were not included in dating analyses because sequences were not available for Crotalus basiliscus or C. totonacus. Estimated divergence dates (Fig. 3.4.1) suggest a basal diversification within the C. m. molossus group likely beginning in the Hemphilian NALMA of the late Miocene 5.1 mya (95\% Highest Posterior Density $=3.30-7.42$ mya), and all clades were present by the mid Pliocene. Mean age for the basal divergence between eastern and western C. m. molossus lineages (including their respective sister taxa) is estimated at $\sim 4.63$ mya (95\% HPD $=2.90-6.67$ mya). Subsequent divergence between $C$. basiliscus and the western C. m. molossus lineage occurred during the early Pliocene $\sim 4.02$ mya (95\% HPD = 2.51-5.94 mya). The initial divergence among western C. m. molossus clades occurred near the Pliocene-Pleistocene boundary $\sim 1.86$ mya $(95 \%$ HPD $=1.03-2.94$ mya). Divergence between C. totonacus and the eastern lineage of C. m. molossus occurred in the early Pliocene $(\sim 3.77$ mya; 95\% HPD 2.25-5.64 mya). However, the basal divergence among clades in the eastern lineage did not occur until the mid-Pleistocene $\sim 0.73$ mya $(95 \%$ HPD $=0.39-1.17$ mya). Geographically, this divergence corresponds to a valley running from southeastern Otero County, New Mexico through south-central Presidio County, Texas. 


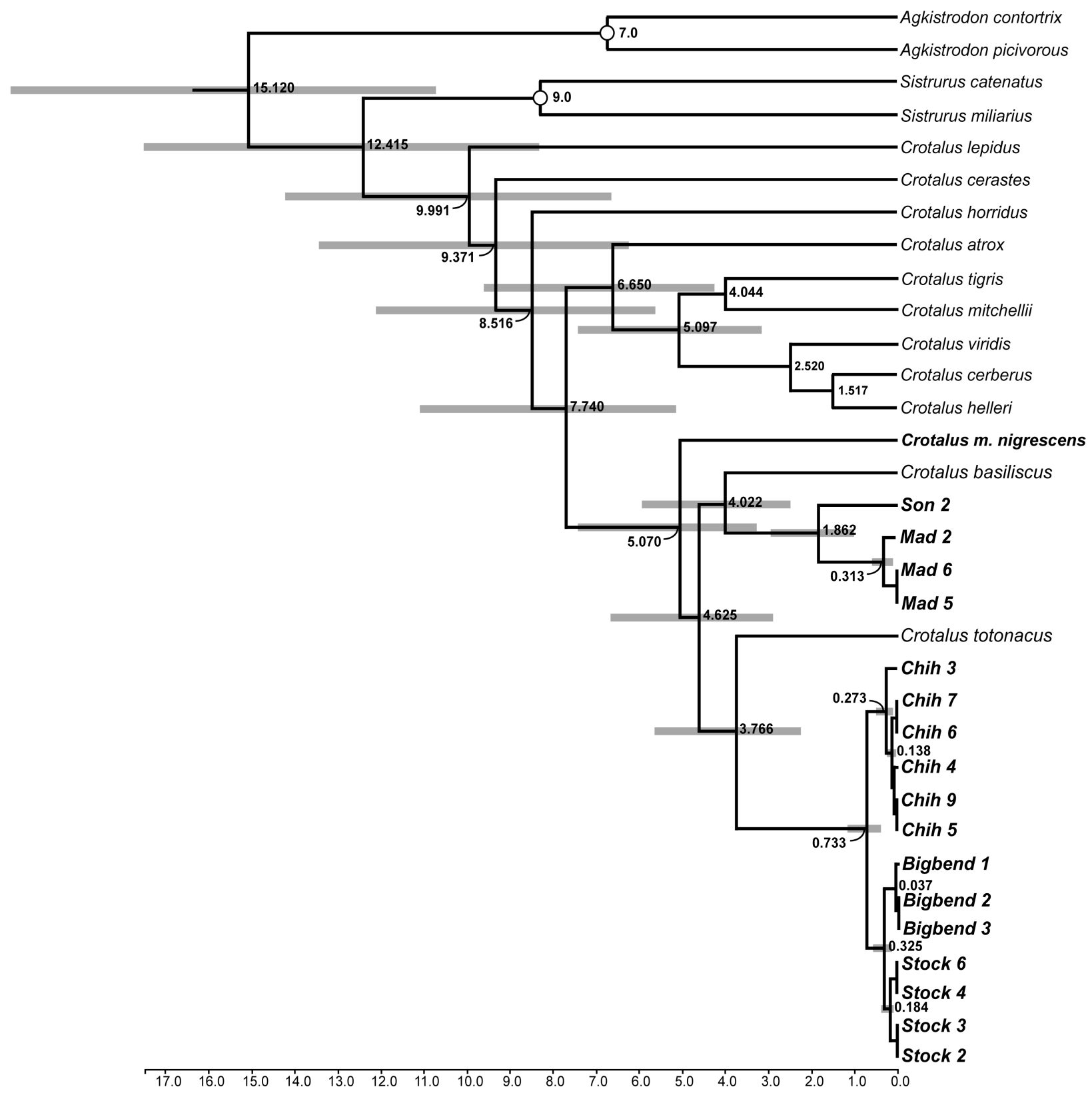

Figure 3.4.1 Cladogram with estimated divergence times for the major lineages within the Crotalus molossus group. Values at nodes are mean divergence dates and bars represent 95\% highest posterior densities; open circles indicate calibration points. Samples representing the currently recognized Crotalus molossus group are in bold text. Abbreviations correspond to five geographically defined clades: Sonoran (Son), Madrean (Mad), Chihuahuan (Chih), Big Bend (Bigbend) and Stockton (Stock). 


\subsection{MORPHOLOGICAL ANALYSES}

Univariate statistics (descriptive statistics, ANOVA and ANCOVA) of morphometric data (Table 3.5.1) did not identify any mensural characters that were significantly different between eastern and western Crotalus m. molossus lineages. However, univariate analysis of the meristic data indicated several characters that might be diagnostic when differentiating between eastern and western C. m. molossus lineages (Table 3.5.2). Informative meristic characters are DBLOT, FDBLOT, DSRV, INAS, PFOV and LOR $(P<0.05)$. Statistically significant differences between eastern and western clades were not observed in any of the qualitative characters; 6 of 101 C.m. molossus (one eastern C.m. molossus, three western C. m. molossus and two C. m. nigrescens) specimens examined lacked a postrostral (POSTROST) scale, and 12 of 101 (two eastern C. m. molossus, four western C. m. molossus and six C. m. nigrescens) exhibited contact between the first supralabial and prenasal (PRE-SUP).

Eigenvalues and principal component (PC) loadings for the first three principal components recorded from PCA of morphometric and meristic datasets are presented in Tables 3.5.3 and 3.5.4, respectively. Principal components analyses of regressed morphometric data did not indicate any differences among lineages of the C. molossus group (Fig. 3.5.1). Loadings from the latter analysis indicated that PC1 is a representation of tail length (TL), and PC2 and PC3 are the influence of head length (HL) and head width (HW) in both males and females. Principal component analyses of raw meristic data indicated morphologically distinct eastern and western C. m. molossus lineages (Fig. 3.5.2). Examination of PC loadings obtained from the raw dataset indicated that PC1 reflects the number of ventral scales (VENT), and PC2 reflects the overall number of dorsal blotches (DBLOT) and the extent of fusion in the dorsal pattern (FDBLOT). The placement of the type specimen of C. molossus (USNM 485) in score plots for 
Table 3.5.1 Descriptive statistics and $P$-values obtained from one-way ANOVA and ANCOVA of regressed meristic data for the eastern and western C. m. molossus lineages.

\begin{tabular}{|c|c|c|c|c|c|}
\hline Character & Lineage & $\begin{array}{c}\text { Mean } \\
\text { (millimeters) }\end{array}$ & SE Mean & StDev & $\begin{array}{c}\boldsymbol{P}-\mathbf{v a l u e} \\
\text { (ANOVA; ANCOVA) }\end{array}$ \\
\hline SVL & $\begin{array}{l}\text { Eastern } \\
\text { Western }\end{array}$ & $\begin{array}{l}778.2 \\
794.7\end{array}$ & $\begin{array}{l}26.0 \\
24.4\end{array}$ & $\begin{array}{l}151.5 \\
117.0\end{array}$ & $0.663 ;-$ \\
\hline TL & $\begin{array}{l}\text { Eastern } \\
\text { Western }\end{array}$ & $\begin{array}{l}56.67 \\
60.05\end{array}$ & $\begin{array}{l}2.38 \\
2.49\end{array}$ & $\begin{array}{l}13.67 \\
11.94\end{array}$ & $0.342 ; 0.402$ \\
\hline HL & $\begin{array}{l}\text { Eastern } \\
\text { Western }\end{array}$ & $\begin{array}{l}40.50 \\
41.41 \\
\end{array}$ & $\begin{array}{l}1.20 \\
1.10\end{array}$ & $\begin{array}{l}6.995 \\
5.289 \\
\end{array}$ & $0.598 ; 0.721$ \\
\hline HW & $\begin{array}{l}\text { Eastern } \\
\text { Western }\end{array}$ & $\begin{array}{l}30.997 \\
31.230 \\
\end{array}$ & $\begin{array}{l}1.15 \\
1.01 \\
\end{array}$ & $\begin{array}{l}6.706 \\
4.825 \\
\end{array}$ & $0.886 ; 0.534$ \\
\hline NOD & $\begin{array}{l}\text { Eastern } \\
\text { Western }\end{array}$ & $\begin{array}{l}6.421 \\
6.526 \\
\end{array}$ & $\begin{array}{l}0.195 \\
0.191 \\
\end{array}$ & $\begin{array}{l}1.137 \\
0.914\end{array}$ & $0.712 ; 0.948$ \\
\hline ID & $\begin{array}{l}\text { Eastern } \\
\text { Western }\end{array}$ & $\begin{array}{l}13.574 \\
13.917 \\
\end{array}$ & $\begin{array}{l}0.428 \\
0.399 \\
\end{array}$ & $\begin{array}{l}2.494 \\
1.915 \\
\end{array}$ & $0.579 ; 0.926$ \\
\hline INAS & $\begin{array}{l}\text { Eastern } \\
\text { Western }\end{array}$ & $\begin{array}{l}6.785 \\
6.983\end{array}$ & $\begin{array}{l}0.201 \\
0.199\end{array}$ & $\begin{array}{l}1.173 \\
0.954\end{array}$ & $0.506 ; 0.680$ \\
\hline RH & $\begin{array}{l}\text { Eastern } \\
\text { Western }\end{array}$ & $\begin{array}{l}4.421 \\
4.470\end{array}$ & $\begin{array}{l}0.157 \\
0.116\end{array}$ & $\begin{array}{l}0.917 \\
0.556\end{array}$ & $0.820 ; 0.798$ \\
\hline $\mathbf{R W}$ & $\begin{array}{l}\text { Eastern } \\
\text { Western }\end{array}$ & $\begin{array}{l}4.747 \\
5.078\end{array}$ & $\begin{array}{l}0.146 \\
0.146\end{array}$ & $\begin{array}{l}0.852 \\
0.701\end{array}$ & $0.129 ; 0.046$ \\
\hline MH & $\begin{array}{l}\text { Eastern } \\
\text { Western }\end{array}$ & $\begin{array}{l}3.662 \\
3.857\end{array}$ & $\begin{array}{l}0.134 \\
0.099\end{array}$ & $\begin{array}{l}0.779 \\
0.474\end{array}$ & $0.289 ; 0.319$ \\
\hline MW & $\begin{array}{l}\text { Eastern } \\
\text { Western }\end{array}$ & $\begin{array}{l}5.147 \\
5.452\end{array}$ & $\begin{array}{l}0.187 \\
0.155\end{array}$ & $\begin{array}{l}1.088 \\
0.743\end{array}$ & $0.247 ; 0.228$ \\
\hline CSL & $\begin{array}{l}\text { Eastern } \\
\text { Western }\end{array}$ & $\begin{array}{l}8.091 \\
7.983\end{array}$ & $\begin{array}{l}0.304 \\
0.227\end{array}$ & $\begin{array}{l}1.772 \\
1.089\end{array}$ & $0.794 ; 0.448$ \\
\hline CSW & $\begin{array}{l}\text { Eastern } \\
\text { Western }\end{array}$ & $\begin{array}{l}3.429 \\
3.552 \\
\end{array}$ & $\begin{array}{l}0.150 \\
0.097\end{array}$ & $\begin{array}{l}0.877 \\
0.467\end{array}$ & $0.542 ; 0.777$ \\
\hline UPH & $\begin{array}{l}\text { Eastern } \\
\text { Western }\end{array}$ & $\begin{array}{l}2.768 \\
2.678\end{array}$ & $\begin{array}{l}0.097 \\
0.074\end{array}$ & $\begin{array}{l}0.565 \\
0.353\end{array}$ & $0.503 ; 0.128$ \\
\hline UPL & $\begin{array}{l}\text { Eastern } \\
\text { Western }\end{array}$ & $\begin{array}{l}4.509 \\
4.448 \\
\end{array}$ & $\begin{array}{l}0.156 \\
0.146 \\
\end{array}$ & $\begin{array}{l}0.912 \\
0.702 \\
\end{array}$ & $0.788 ; 0.329$ \\
\hline LPH & $\begin{array}{l}\text { Eastern } \\
\text { Western }\end{array}$ & $\begin{array}{l}1.303 \\
1.452 \\
\end{array}$ & $\begin{array}{l}0.055 \\
0.067 \\
\end{array}$ & $\begin{array}{l}0.323 \\
0.323 \\
\end{array}$ & $0.093 ; 0.030$ \\
\hline LPL & $\begin{array}{l}\text { Eastern } \\
\text { Western }\end{array}$ & $\begin{array}{l}5.082 \\
5.174\end{array}$ & $\begin{array}{l}0.175 \\
0.140\end{array}$ & $\begin{array}{l}1.019 \\
0.672\end{array}$ & $0.707 ; 1.000$ \\
\hline PFL & $\begin{array}{l}\text { Eastern } \\
\text { Western }\end{array}$ & $\begin{array}{l}3.915 \\
4.091 \\
\end{array}$ & $\begin{array}{l}0.137 \\
0.113 \\
\end{array}$ & $\begin{array}{l}0.800 \\
0.540\end{array}$ & $0.359 ; 0.376$ \\
\hline PFW & $\begin{array}{l}\text { Eastern } \\
\text { Western }\end{array}$ & $\begin{array}{l}5.212 \\
5.500\end{array}$ & $\begin{array}{l}0.192 \\
0.178\end{array}$ & $\begin{array}{l}1.118 \\
0.855\end{array}$ & $0.300 ; 0.313$ \\
\hline SOCL & $\begin{array}{l}\text { Eastern } \\
\text { Western }\end{array}$ & $\begin{array}{l}8.847 \\
8.926\end{array}$ & $\begin{array}{l}0.263 \\
0.286\end{array}$ & $\begin{array}{l}1.532 \\
1.373\end{array}$ & $0.843 ; 0.752$ \\
\hline SOCW & $\begin{array}{l}\text { Eastern } \\
\text { Western }\end{array}$ & $\begin{array}{l}4.927 \\
4.917 \\
\end{array}$ & $\begin{array}{l}0.165 \\
0.169\end{array}$ & $\begin{array}{l}0.960 \\
0.809\end{array}$ & $0.970 ; 0.314$ \\
\hline
\end{tabular}


Table 3.5.2 Descriptive statistics and $P$-values obtained from one-way ANOVA of meristic data for the eastern and western C.m. molossus lineages.

\begin{tabular}{|c|c|c|c|c|c|}
\hline Character & Lineage & Mean & SE Mean & StDev & $P$-value \\
\hline VENT* & $\begin{array}{l}\text { Eastern } \\
\text { Western }\end{array}$ & $\begin{array}{l}189.47 \\
190.49\end{array}$ & $\begin{array}{l}0.588 \\
0.754\end{array}$ & $\begin{array}{l}3.86 \\
4.71\end{array}$ & 0.284 \\
\hline SCDL* & $\begin{array}{l}\text { Eastern } \\
\text { Western }\end{array}$ & $\begin{array}{l}23.279 \\
22.795 \\
\end{array}$ & $\begin{array}{l}0.370 \\
0.455 \\
\end{array}$ & $\begin{array}{l}2.423 \\
2.839 \\
\end{array}$ & 0.407 \\
\hline DBLOT & $\begin{array}{l}\text { Eastern } \\
\text { Western }\end{array}$ & $\begin{array}{l}28.762 \\
31.977 \\
\end{array}$ & $\begin{array}{l}0.399 \\
0.454 \\
\end{array}$ & $\begin{array}{l}2.583 \\
2.980 \\
\end{array}$ & 0.000 \\
\hline FDBLOT & $\begin{array}{l}\text { Eastern } \\
\text { Western }\end{array}$ & $\begin{array}{l}8.405 \\
1.907 \\
\end{array}$ & $\begin{array}{l}0.279 \\
0.413 \\
\end{array}$ & $\begin{array}{l}1.809 \\
2.706 \\
\end{array}$ & 0.000 \\
\hline DSRN & $\begin{array}{l}\text { Eastern } \\
\text { Western }\end{array}$ & $\begin{array}{l}30.786 \\
31.140 \\
\end{array}$ & $\begin{array}{l}0.179 \\
0.241 \\
\end{array}$ & $\begin{array}{l}1.159 \\
1.582 \\
\end{array}$ & 0.244 \\
\hline DSRM & $\begin{array}{l}\text { Eastern } \\
\text { Western }\end{array}$ & $\begin{array}{l}26.929 \\
26.977\end{array}$ & $\begin{array}{l}0.110 \\
0.174\end{array}$ & $\begin{array}{l}0.712 \\
1.144\end{array}$ & 0.817 \\
\hline DSRV & $\begin{array}{l}\text { Eastern } \\
\text { Western }\end{array}$ & $\begin{array}{l}20.405 \\
20.814 \\
\end{array}$ & $\begin{array}{l}0.128 \\
0.142 \\
\end{array}$ & $\begin{array}{l}0.828 \\
0.932 \\
\end{array}$ & 0.036 \\
\hline PFRO & $\begin{array}{l}\text { Eastern } \\
\text { Western }\end{array}$ & $\begin{array}{l}2.143 \\
2.163 \\
\end{array}$ & $\begin{array}{l}0.073 \\
0.081 \\
\end{array}$ & $\begin{array}{l}0.4722 \\
0.5314 \\
\end{array}$ & 0.856 \\
\hline INAS & $\begin{array}{l}\text { Eastern } \\
\text { Western }\end{array}$ & $\begin{array}{l}2.333 \\
2.930 \\
\end{array}$ & $\begin{array}{l}0.126 \\
0.227 \\
\end{array}$ & $\begin{array}{l}0.816 \\
1.486 \\
\end{array}$ & 0.025 \\
\hline ISO & $\begin{array}{l}\text { Eastern } \\
\text { Western }\end{array}$ & $\begin{array}{l}5.571 \\
5.256 \\
\end{array}$ & $\begin{array}{l}0.153 \\
0.205 \\
\end{array}$ & $\begin{array}{l}0.991 \\
1.347 \\
\end{array}$ & 0.223 \\
\hline SUPRA & $\begin{array}{l}\text { Eastern } \\
\text { Western }\end{array}$ & $\begin{array}{l}17.167 \\
17.372 \\
\end{array}$ & $\begin{array}{l}0.148 \\
0.191\end{array}$ & $\begin{array}{l}0.961 \\
1.254\end{array}$ & 0.400 \\
\hline INFRA & $\begin{array}{l}\text { Eastern } \\
\text { Western }\end{array}$ & $\begin{array}{l}17.286 \\
17.442\end{array}$ & $\begin{array}{l}0.129 \\
0.161\end{array}$ & $\begin{array}{l}0.835 \\
1.053\end{array}$ & 0.425 \\
\hline SFOV & $\begin{array}{l}\text { Eastern } \\
\text { Western }\end{array}$ & $\begin{array}{l}0.833 \\
0.605\end{array}$ & $\begin{array}{l}0.076 \\
0.089\end{array}$ & $\begin{array}{l}0.4897 \\
0.5831\end{array}$ & 0.054 \\
\hline PFOV & $\begin{array}{l}\text { Eastern } \\
\text { Western }\end{array}$ & $\begin{array}{l}7.595 \\
9.465 \\
\end{array}$ & $\begin{array}{l}0.271 \\
0.300 \\
\end{array}$ & $\begin{array}{l}1.754 \\
1.968 \\
\end{array}$ & 0.000 \\
\hline LOR & $\begin{array}{l}\text { Eastern } \\
\text { Western }\end{array}$ & $\begin{array}{l}3.333 \\
4.023 \\
\end{array}$ & $\begin{array}{l}0.179 \\
0.214 \\
\end{array}$ & $\begin{array}{l}1.162 \\
1.406 \\
\end{array}$ & 0.016 \\
\hline
\end{tabular}

* Sexually dimorphic characters, mean VENT female = 192.00 (eastern), 193.67 (western); mean VENT male $=187.27$ (eastern), 188.56 (western). Mean SCDL female = 20.783 (eastern), 20.167 (western); mean SCDL male = 25.182 (eastern), 24.556 (western). 

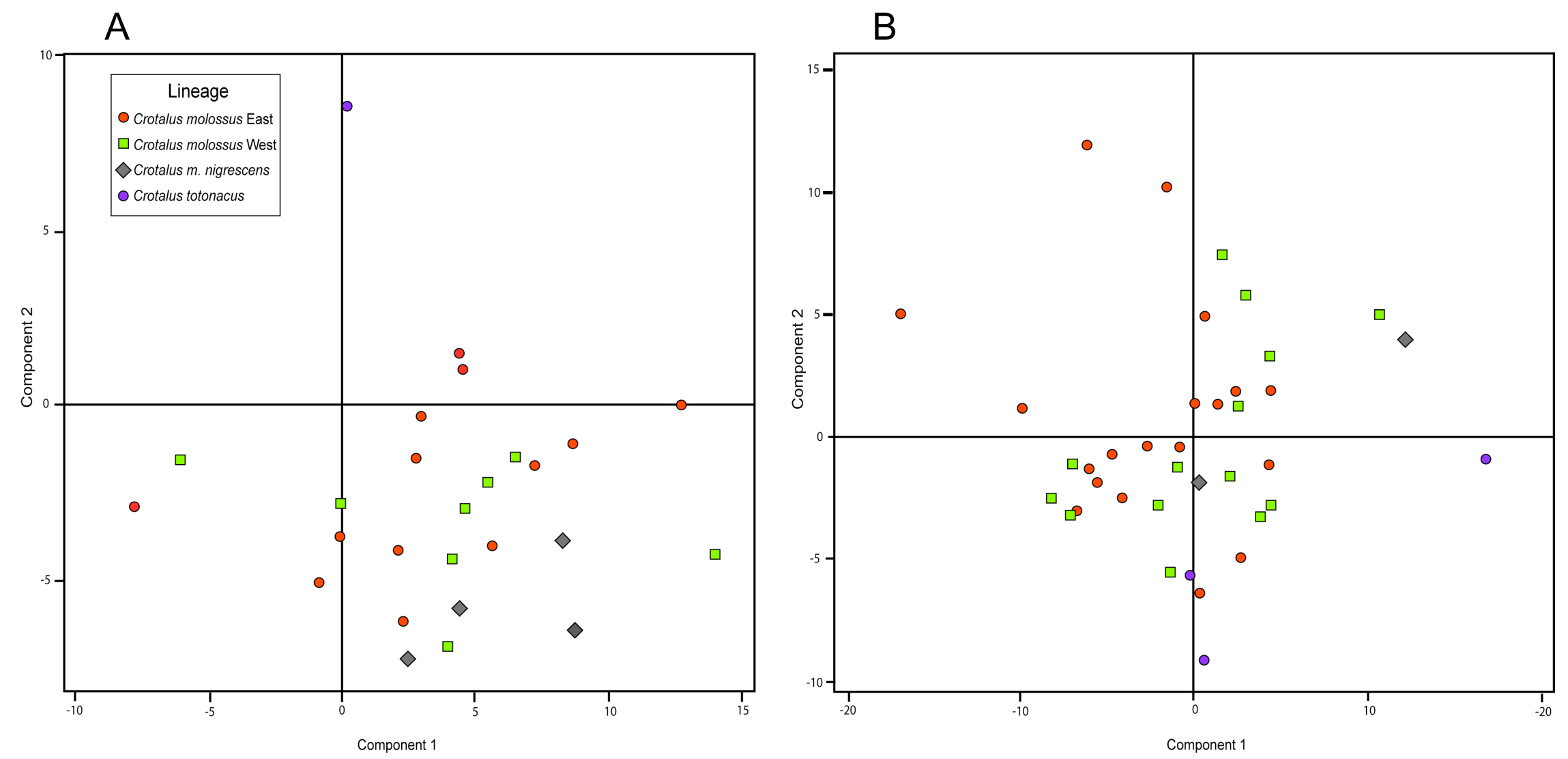

Figure 3.5.1 Score plots of first and second principal components obtained from PCA of morphometric data regressed against SVL for female (A) and male (B) specimens representing Crotalus m. molossus (eastern and western lineages), C. m. nigrescens and C. totonacus. 


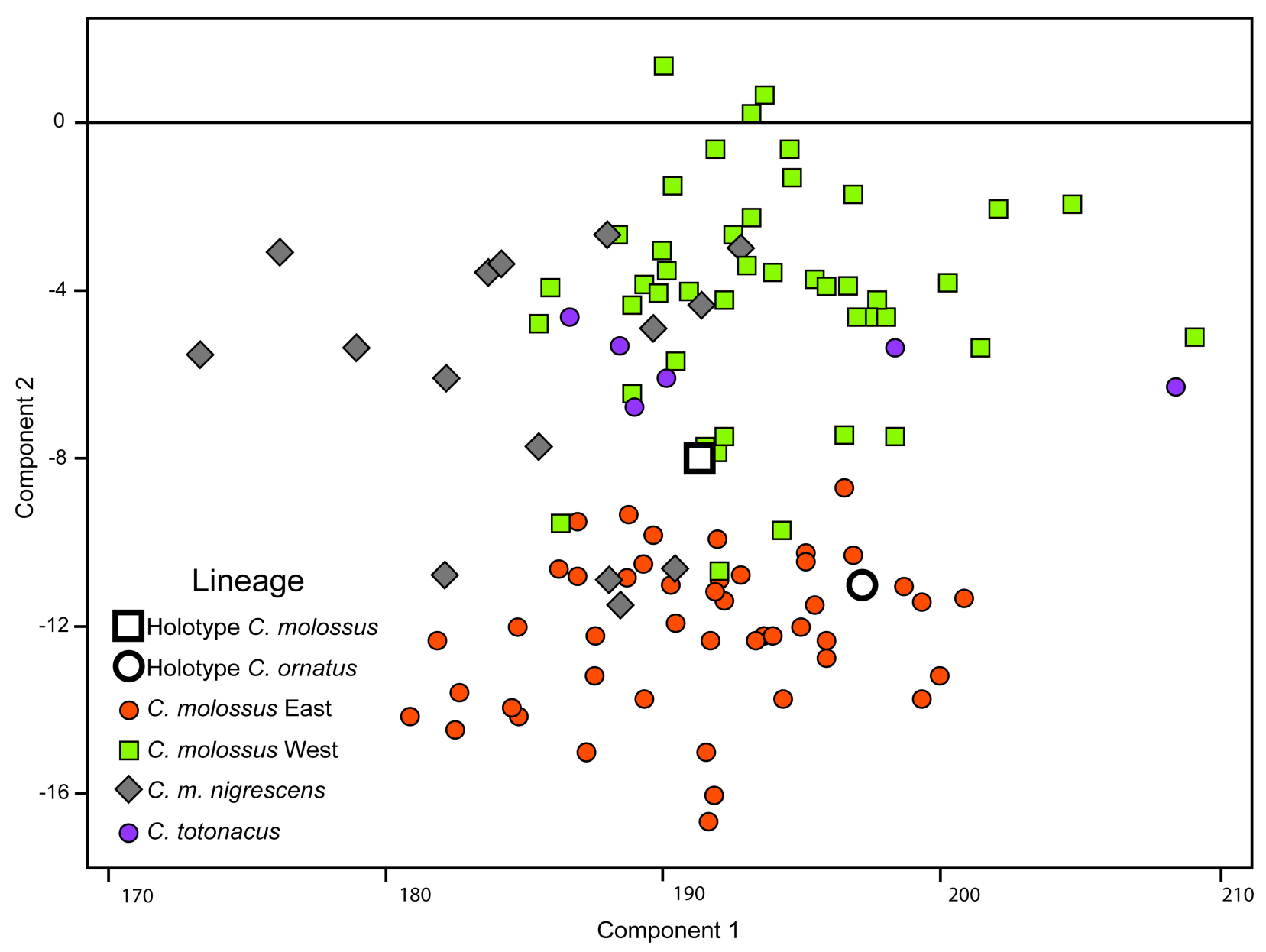

Figure 3.5.2 Score plots of first and second principal components obtained from PCA of raw meristic data representing Crotalus m. molossus (eastern and western lineages), C. m. nigrescens, C. totonacus, and type specimens of C. ornatus and C. molossus.

both the raw and standardized (not shown) datasets suggests that this specimen was collected from the western lineage. 
Table 3.5.3 Eigenvalues and PC loadings obtained from a PCA of morphometric data for female and male specimens representing Crotalus m. molossus (eastern and western lineages), C. m. nigrescens and $C$. totonacus.

\begin{tabular}{l|lrr|rrr}
\multicolumn{1}{c}{} & \multicolumn{3}{c}{ Females } & \multicolumn{3}{c}{ Males } \\
& PC1 & \multicolumn{1}{c}{ PC2 } & \multicolumn{1}{c}{ PC3 } & \multicolumn{1}{c}{ PC1 } & \multicolumn{1}{c}{ PC2 } & \multicolumn{1}{c}{ PC3 } \\
\hline Eigenvalue & $\mathbf{2 5 . 4 1 8}$ & $\mathbf{1 1 . 1 4 2}$ & $\mathbf{2 . 1 6 8}$ & $\mathbf{4 3 . 3 3 4}$ & $\mathbf{1 9 . 4 5 4}$ & $\mathbf{2 . 3 9 3}$ \\
Proportion & $\mathbf{0 . 6 1 4}$ & $\mathbf{0 . 2 6 9}$ & $\mathbf{0 . 0 5 2}$ & $\mathbf{0 . 6 1 4}$ & $\mathbf{0 . 2 7 6}$ & $\mathbf{0 . 0 3 4}$ \\
TL & 0.959 & 0.260 & -0.072 & 0.982 & -0.048 & -0.171 \\
HL & 0.217 & -0.559 & 0.620 & 0.110 & 0.662 & 0.465 \\
HW & 0.124 & -0.631 & -0.738 & -0.094 & 0.650 & -0.721 \\
NOD & 0.047 & -0.085 & 0.066 & 0.035 & 0.125 & 0.104 \\
ID & 0.044 & -0.253 & 0.112 & 0.055 & 0.185 & 0.293 \\
INAS & 0.035 & -0.122 & 0.103 & 0.022 & 0.076 & 0.099 \\
RH & 0.037 & -0.085 & 0.086 & 0.032 & 0.061 & 0.176 \\
RW & 0.006 & -0.074 & 0.039 & 0.031 & 0.063 & 0.118 \\
MH & 0.005 & -0.152 & 0.038 & -0.007 & 0.065 & -0.033 \\
MW & 0.029 & -0.120 & 0.102 & 0.024 & 0.065 & 0.009 \\
CSL & 0.027 & -0.114 & 0.084 & 0.075 & 0.045 & 0.091 \\
CSW & 0.044 & -0.102 & -0.009 & 0.008 & 0.027 & -0.030 \\
UPH & 0.006 & -0.178 & 0.014 & 0.016 & 0.175 & 0.159 \\
UPL & 0.022 & -0.050 & 0.042 & 0.030 & 0.062 & 0.151 \\
LPH & 0.046 & -0.058 & 0.020 & 0.024 & 0.090 & -0.003 \\
LPL & 0.033 & -0.015 & 0.039 & 0.005 & 0.041 & 0.024 \\
PFL & 0.041 & -0.096 & 0.029 & 0.020 & 0.081 & 0.044 \\
PFW & 0.017 & -0.018 & -0.016 & 0.002 & 0.020 & 0.034 \\
SOCL & 0.024 & -0.072 & 0.014 & 0.013 & 0.074 & 0.054 \\
SOCW & 0.032 & -0.102 & 0.070 & 0.013 & 0.082 & 0.138 \\
\hline
\end{tabular}

Table 3.5.4 Eigenvalues and PC loadings obtained from a PCA of raw meristic data from specimens representing Crotalus m. molossus (eastern and western lineages), C. m. nigrescens and $C$. totonacus.

\begin{tabular}{l|rrr}
\multicolumn{1}{c}{ PC1 } & PC2 & PC3 \\
\hline Eigenvalue & $\mathbf{3 4 . 8 4 3}$ & $\mathbf{1 7 . 8 8 1}$ & $\mathbf{1 0 . 6 8 1}$ \\
Proportion & $\mathbf{0 . 4 0 0}$ & $\mathbf{0 . 2 0 5}$ & $\mathbf{0 . 1 2 3}$ \\
DBLOT & 0.135 & 0.396 & 0.630 \\
FDBLOT & -0.001 & -0.891 & 0.232 \\
DSRN & 0.110 & -0.051 & -0.100 \\
DSRM & 0.072 & -0.036 & -0.026 \\
DSRV & 0.047 & 0.023 & -0.063 \\
VENT & 0.964 & -0.068 & 0.050 \\
SCDL & -0.124 & -0.024 & 0.678 \\
PFRO & 0.008 & 0.000 & -0.014 \\
INAS & 0.060 & 0.055 & -0.063 \\
ISO & 0.038 & -0.067 & -0.084 \\
SUPRA & 0.037 & -0.050 & -0.074 \\
INFRA & 0.023 & -0.022 & -0.103 \\
SFOV & 0.000 & -0.017 & -0.021 \\
PFOV & 0.079 & 0.159 & -0.191 \\
LOR & 0.065 & 0.057 & -0.090 \\
\hline
\end{tabular}




\subsection{TAXONOMY OF CROTALUS MOLOSSUS}

The eastern lineage of Crotalus m. molossus inferred by Wüster et al. (2005) and the present study is morphologically and genetically distinct from the western lineage. The phylogenetic analyses of this study recovered strongly supported, reciprocally monophyletic eastern and western $C . m$. molossus lineages. The uncorrected pairwise mtDNA divergence calculated between eastern and western lineages (7.6-7.9\%) is comparable to or surpasses values reported between currently recognized rattlesnake species (e.g., C. mitchellii and C. stephansi, 5.2-7.3\% [Douglas et al. 2007]; $C$. viridis and C. oreganus, 3.5-5.6\% [Pook et al. 2000]; $C$. atrox and C. ruber, 4.61\% [Castoe et al. 2007]). Monophyly of the C. molossus group was rejected by $\mathrm{AU}$ and $\mathrm{SH}$ tests. Population-level analyses indicated that the eastern and western lineages are separated by 142 mutations, and mismatch distributions suggest that these clades are stable and have not been in contact since their divergence in the early Pliocene. Univariate statistical analyses identified distinct morphological character states between the lineages (dorsal blotches and the extent of fusion between anterior dorsal blotches, dorsal scale rows anterior to the vent, internasals, prefoveals and loreals), and PC analyses of meristic data clearly delineated distinct eastern and western lineages. Given these substantial differences between the eastern and western lineages of $C . m$. molossus, I recognize each of them as a distinct species, and resurrect the name Crotalus ornatus Hallowell 1854 for the eastern lineage. Under the Evolutionary Species Concept (Simpson 1961; Wiley 1978) and its more recent incarnation, the General Lineage Concept (de Queiroz 1998, 1999), a species is a lineage with an evolutionary path that is distinct from other lineages. Furthermore, the General Lineage Concept simplifies species delineation by removing the prerequisites (e.g., morphological distinctness, reproductive 
isolation or ecological divergence) that had to be met under previous species concepts, and only requires that a species be evolving separately from other lineages.

\subsection{TAXONOMY OF CROTALUS MOLOSSUS SENSU STRICTO}

Baird and Girard (1853) described Crotalus molossus from USNM 485, an adult male collected from Fort Webster, Santa Rita Del Cobre mine, New Mexico. This locality is about 4.5 $\mathrm{km}$ northeast of the town of Bayard in Grant Co. New Mexico, and seems to be at or near the biogeographical boundary that differentiates the eastern and western C. m. molossus lineages. Specimens collected from within $75 \mathrm{~km}$ north and $35 \mathrm{~km}$ west of this locality have been unequivocally identified as members of the western lineage. Two samples, one collected from $\sim 62 \mathrm{~km}$ northeast and the other $\sim 60 \mathrm{~km}$ southeast of the type locality, were recovered within the eastern lineage. Interestingly, a specimen collected in the town of Bayard (UTEP 20155) may be a hybrid-it was recovered in analyses of the mtDNA and six-gene datasets as C.atrox, whereas analyses of the combined nDNA dataset recovered this specimen in the Madrean clade with moderate support ( $80 \% \mathrm{MP} ; 67 \% \mathrm{ML} ; 0.92 \mathrm{BI}$ ). The description of the holotype provided by Baird and Girard (1853) reported a ground color of "roll sulfur." Examination of live specimens, color photos in the UTEP collection and published color plates (Campbell and Lamar 1989, 2004; Beaman and Hayse 2008) suggest that a ground color of pale to bright yellow is typical for the Madrean clade. However, Baird and Girard (1853) noted extensive fusion of anterior dorsal blotches, a character state common in the eastern lineage. Baird and Girard (1853) reported the following scale counts for the holotype: two frontals, four prefrontals, two internasals, five interoculabials, 18 supralabials, 17 infralabials and 29 dorsal scale rows at midbody. These are

consistent with the values that I recorded from USNM 485. In addition, I recorded 33 and 22 
dorsal scale rows at the neck and anterior to the vent, respectively, 188 ventrals, 26 subcaudals, six intersupraoculars, no subfoveals, 13 prefoveals and five loreals. This specimen is preserved as a skin with the head and tail attached and is in relatively good condition. However, the color pattern has faded somewhat and only 22 dorsal blotches (five of them fused) are visible before the extent of fading obscures the color pattern at about the $135^{\text {th }}$ ventral. The following measurements were recorded; tail length $=62 \mathrm{~mm}$, head length $=43.1 \mathrm{~mm}$, head width $=35.6$ mm. Baird and Girard (1853) did not report measurements in their description and an accurate SVL could not be measured from the skin. However, an estimated SVL of $\sim 77-83 \mathrm{~cm}$ for the holotype was obtained from mean values for ratios of head length to SVL and tail length to SVL for male specimens of $C$. m. molossus used in this study. The SVL of the holotype in life would have been slightly larger as fluid preserved specimens are known to experience distortion and shrinkage during preservation (Vervust et al. 2009). Three character states place USNM 485 in the western lineage, including DSRV (22), PFOV (13) and LOR (5). The presence of five fused dorsal blotches (FDBLOT) is high compared to the mean of 1.91 for the western lineage, yet this value is well within the variance of 7.32. Based on inference of nDNA data obtained from UTEP 20155 collected near the type locality, the morphological data collected from the type specimen, and the description of the specimen in life provided by Baird and Girard (1853), I conclude that USNM 485 was collected from a population within the Madrean clade of the western C.m. molossus lineage.

\subsection{REDISCRIPTION OF CROTALUS ORNATUS}

Holotype.-An adult female (USNM 486 [Fig. 3.8.1]) collected by A. Heermann, from a locality "near Pecos River, N. W. Texas." The specimen was collected during the survey of a 


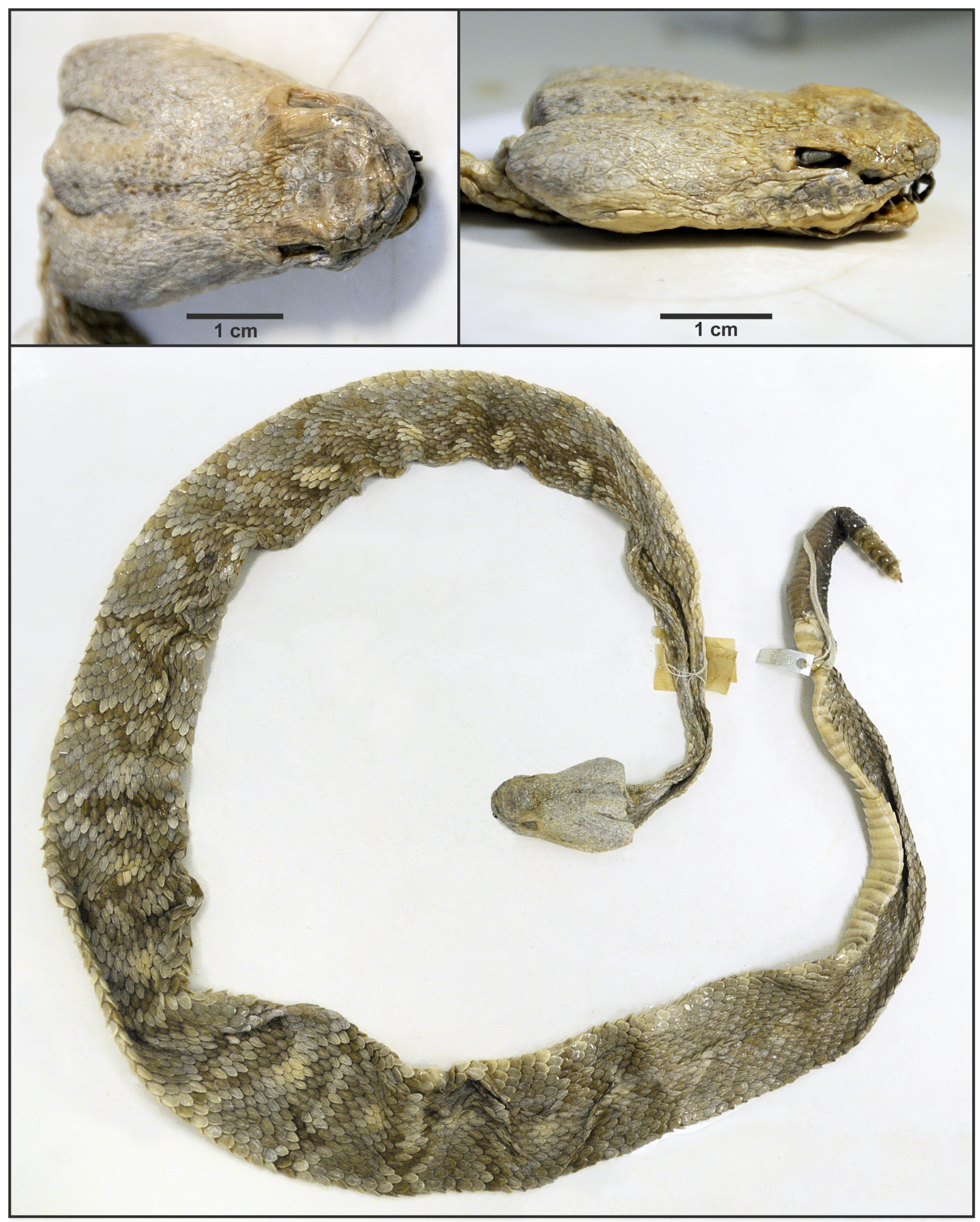

Figure 3.8.1 Head and body of the holotype of Crotalus ornatus, USNM 486. 
railroad route to the Pacific, led by Lieutenant Parke, U.S. Top Engineer (collection date unknown).

Diagnosis. Crotalus ornatus (Fig. 3.8.2) can be distinguished from most congeners by having: (1) a medium sized SVL (adults 70-100 cm, rarely to $130 \mathrm{~cm} \mathrm{SVL);} \mathrm{(2)} \mathrm{two} \mathrm{large,}$ triangular internasal scales; (3) two large prefrontals; (4) two large frontal scales; (5) 6-10 prefoveals; (6) 2-4 loreals; (7) two preoculars; (8) five postoculars; (9) 2-7 intersupraoculars; (10) 16-18 supralabials; (11) 14-21 infralabials; (12) 23-29 dorsal scale rows at midbody; (13) 164-205 ventrals; (14) 16-30 subcaudals (16-26 in females and 21-30 males); (15) internasalprefrontal region and supraoculars black or dark brown; (16) dark pigmentation of dorsal pattern extends from nape to occipital and parietal regions; (17) 22-33 (mean = 29) rhomboid dorsal body blotches that often coalesce with lateral blotches at midbody to form bands or chevrons (dorsal blotches of some specimens may become diffuse posteriorly, represented by barely distinct or absent bands anterior to vent); (18) light medial spots longer than wide on anterior portion of body, becoming broader at midbody separating dorsal blotches; (19) medial spots often become indistinguishable from ground color on posterior $1 / 4$ of body; (20) two white or light grey, irregular paravertebral spots present within each dorsal blotch, usually separated by 1-6 dorsal scales rows on anterior portion of body, but darken slightly and grow to extend across midline of dorsum to fill interior of dorsal blotches on posterior $\frac{1}{12}$ of body; (21) tail black or dark brown with faint cross-bands sometimes visible; (22) proximal rattle segment black or dark brown (Tables 3.5.1 and 3.5.2).

Comparisons.-Crotalus ornatus is unique among C. molossus lineages in having 4-11 prefoveals; 2-7 loreals; a ground color of gray, olive-green, olive-brown, or tan; 22-33 rhombic dorsal blotches, each separated by a light gray, white or pale yellow medial spot; and anterior 6- 

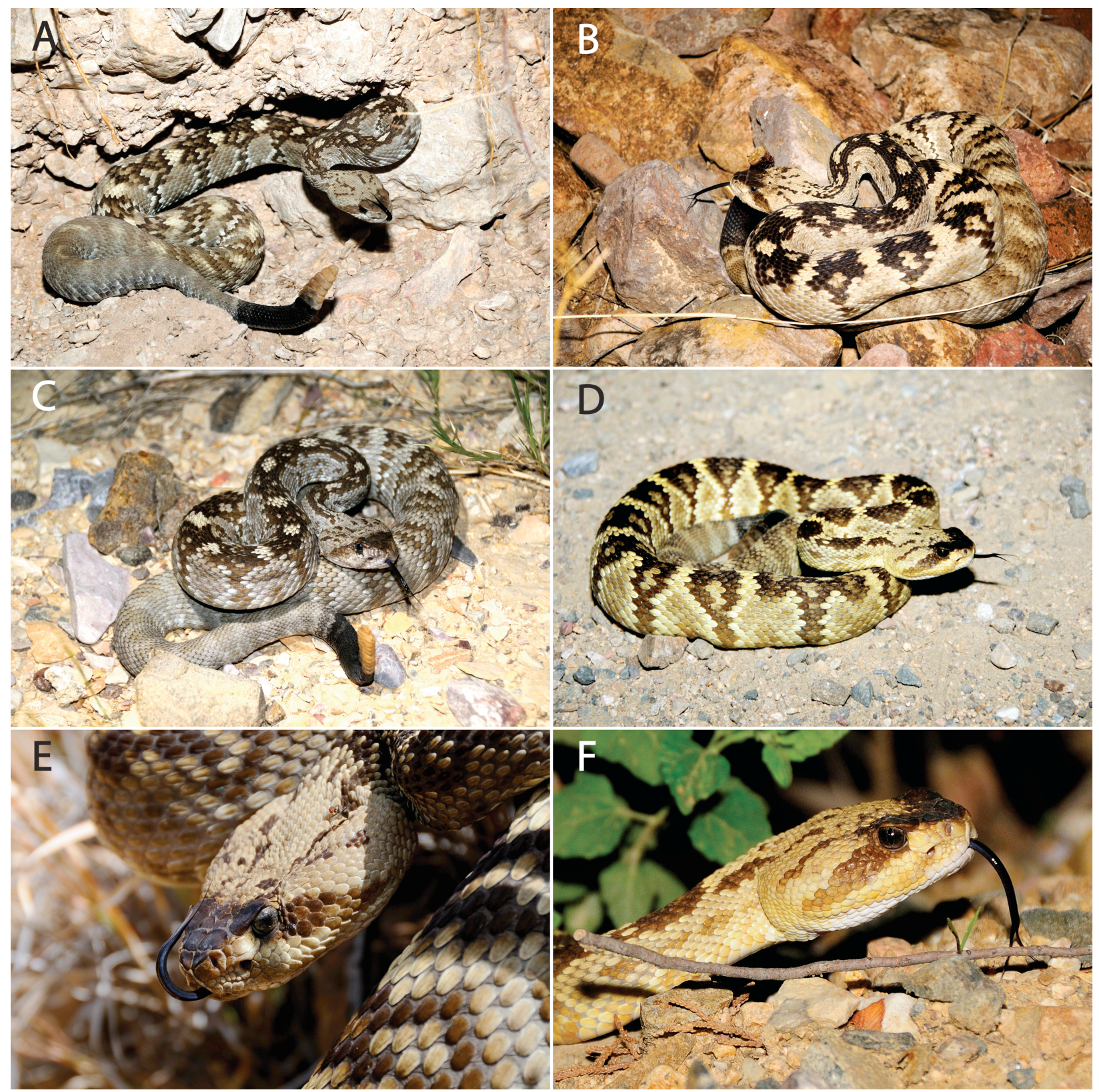

Figure 3.8.2 Representative specimens of Crotalus ornatus and C. molossus in life: (A) $C$. ornatus, Hueco Mountains, El Paso Co., Texas; (B) C. ornatus, Davis Mountains, Jeff Davis Co., Texas (CGA 06); (C) C. ornatus, Terlingua, Brewster Co., Texas; (D) C. molossus sensu stricto, Santa Rita Mountains, Santa Cruz Co., Arizona; (E) side profile of head of C. ornatus, Chisos Mountains, Big Bend National Park, Brewster Co., Texas; (F) side profile of head of C. molossus sensu stricto, Santa Rita Mountains, Santa Cruz Co., Arizona. With the exception of CGA 06, the photographed animals were not collected. 
10 dorsal blotches connected by 1-3 scale rows, often resembling paravertebral stripes or a thick dorsal stripe surrounding light medial spots. Crotalus ornatus most closely resembles $C$. molossus sensu stricto, but can be distinguished from the latter taxon by its lower average scale counts $(P<0.001)$ for prefoveals ( 8 vs. 10$)$ and loreals ( 3 vs. 4$)$, fewer dorsal blotches (29 vs. 32) and a dorsal blotch pattern where the first 6-10 dorsal blotches are almost always connected (dorsal blotches are almost always separated by a light medial spot in C. molossus sensu stricto). Crotalus ornatus can be distinguished from C. m. nigrescens and C. m. oaxacus by having a higher number of dorsal scale rows at midbody ( 27 vs. 25 ), a higher number of ventrals (up to 205 in females vs. 187 in C. m. nigrescens and fewer in C. m. oaxacus [Klauber 1972]), dark pigmentation on the head restricted to the internasal-prefrontal area, with thin (1 scale row wide), sometimes ornate lines on the occipital and parietal regions (extensive pigmentation often covers most of the head of the latter two lineages), and light medial and paravertebral spots in the dorsal pattern (usually absent in the latter two taxa). In C.m. oaxacus it is common for adults to retain black and white tail rings common in juveniles of the C. molossus group (Campbell and Lamar 1989, 2004), but this character does not persist to adulthood in C. ornatus.

Crotalus ornatus is most easily distinguished from C. estebanensis by geographic distribution; the former is widespread throughout most of the Chihuahuan Desert, whereas the latter is an insular endemic in the Gulf of California. Morphologically, C. ornatus differs from C. estebanensis in having relatively dark dorsal blotches that create a dorsal pattern that boldly contrasts with the ground color (dorsal blotches are paler and the pattern moderately contrasting with the ground color in C. estebanensis), and dark pigmentation on the head in the internasalprefrontal area of $C$. ornatus lacks dark coloration in the prefrontal-internasal area (absent in $C$. estebanensis) (Grismer 1999; Campbell and Lamar 2004). Klauber (1949) noted longitudinal and 
transverse compression of the rattle of $C$. estebanensis as a character unique among members of the $C$. molossus group, which includes $C$. ornatus.

Crotalus ornatus differs from C. totonacus in being smaller (rarely to $125 \mathrm{~cm}$ vs. commonly exceeding $150 \mathrm{~cm}$ ), in having a larger number of intersupraoculars (5 vs. 1 or 2 ), prefoveals (8 vs. 3 or 4 ), supralabials (17 vs. 14) and infralabials (17 vs. 15), in having an anterior dorsal pattern of interconnected but usually distinct dorsal blotches (paravertebral stripes [usually without distinct blotches] on the neck transition into an intricate pattern on the head in C. totonacus), and by the lack of a vertebral ridge (relatively well developed in C. totonacus) (Campbell and Lamar 2004).

Description of the holotype.- Rostral about as high as wide; internasals (2) large and triangular, in contact medially, anterior medial portion contacts apex of rostral; prefrontals (2) large and roughly square, in contact medially, anterior edge broadly contacts prenasal and partially contacts postnasal scale; frontals (2) large and roughly square, anterior in broad contact with prefrontals, mostly in contact medially but separated anteriorly by a single small scale, posterior border rounded and followed by intersupraoculars (7); prenasal large and rectangular, upper edge in broad contact with internasal and partial contact with postnasal, anterior portion broadly contacts rostral; postnasal irregular, surrounds upper, lower and posterior borders of nostril; loreals (3) prevent contact between postnasal and preoculars; postsupraloreal (canthal) roughly square and in contact with supraloreal, upper preocular, supraocular (see remarks) and prefrontal; supraloreal round, in contact with postsupraloreal, upper and lower preoculars, infraloreal, postrostral and prefrontal; infraloreal irregular, in contact with supraloreal, lower preocular, upper lacunal, two upper prefoveals and postnasal; preoculars (2) in contact with supraocular, loreals and upper lacunal (see remarks); prefoveals (9), the largest anterior scale is 
in broad contact with rostral and together with second prefoveal prevents contact between prenasal and first supralabial; lacunals (3) are partially visible on exterior margin of loreal pit; supralabials (18) separated from prenasal, postnasal and infraloreal by prefoveals, fourth (and possibly fifth) in contact with lower lacunal scale; 17 infralabials; dorsal scale rows are 33/27/20; ventrals are 194 and subcaudals are 19.

Measurements of the holotype.-The holotype is an adult female; Hallowell (1854) reported the following measurements: body length $=41$ inches $($ in. $)(\sim 104 \mathrm{~cm})$; tail length $=2$ in. $(\sim 5.1 \mathrm{~cm})$; head length $=1.75 \mathrm{in} .(\sim 45 \mathrm{~mm})$; and head width $=1.5 \mathrm{in} .(\sim 38 \mathrm{~mm})$. Reexamination of the specimen recovered the following measurements: tail length $=4.8 \mathrm{~cm}$; head length $=46.1$ $\mathrm{mm}$; head width $=32.4 \mathrm{~mm}$ (see remarks); and interocular distance $=14.2 \mathrm{~mm}$. Because the specimen is preserved as a skin with head and tail attached, SVL could not be accurately measured (see remarks).

Coloration of the holotype.-Dorsum of head grayish and beige with brown and tan appearing in internasal-prefrontal area with some brown flecking on scales of the anterior occipital region; dorsum of body gray with 24 brown, rhomboid dorsal blotches, seven (anterior) connected by one or more scale rows; medial spots off white, anterior spots roughly as long as wide, but becoming wider at midbody; paravertebral spots gray, distinct on anterior of body but expand and connect dorsally to fill interior of dorsal blotches by midbody; tail and proximal rattle segment black; gular area lacking dark pigmentation but stained beige or yellowish; venter mostly off white or yellow with slight gray mottling at midbody, which becomes more extensive posteriorly; ventral surface of tail dark gray.

Distribution.-With the exception of populations occupying the Edward's Plateau of central Texas, the northern Chihuahuan Desert defines the geographical distribution of Crotalus 
ornatus. Meristic analyses of specimens from northern Mexico suggest that $C$. ornatus is present as far south as central Coahuila, Mexico in the mountains of the Cuatro Ciénegas Basin. The southern border for the lineage is unclear with available data. However, records for $C . m$. nigrescens (Klauber 1972; Campbell and Lamar 2004) suggest that the distribution of C. ornatus likely terminates at a boundary in southern Coahuila. Numerous authors have suggested a biogeographical barrier in northern Durango and southern Coahuila to explain divergences between species in the northern and southern Chihuahuan Desert (e.g., Baker 1956; Peterson 1976; Hafner et al. 2008). In this region, the Río Nazas flows from its source in the Sierra Madre Occidental of north-central Durango and terminates in the Laguna de Mayrán (Conant 1963), part of an arid bolson known as the Parras Basin that transects southern Coahuila (Krutak 1967). The Parras Basin is bordered by extensions of the Sierra Madre Oriental to the south and the Coahuila Peninsula and Coahuila Marginal Folded Belt to the north (Krutak 1967). Baker (1956) suggested that the Southern Coahuila Filter Barrier is defined by the Río Nazas, Parras Basin and the mountain ranges south of the basin. The arid bolson of this barrier would present a formidable obstacle for any montane or semi-montane species, and is likely the southern boundary for $C$. ornatus. However, montane corridors may allow contact with $C$. m. nigrescens in southeastern Coahuila and western Nuevo León. Gloyd (1940) suggested a zone of intergradation near Galeana, Nuevo León, Mexico, which is well outside of the currently recognized range of the northern black-tailed rattlesnake.

The geographic boundaries of Crotalus ornatus in the Mexican state of Chihuahua are less clear. In the absence of a biogeographic barrier in this area, it may be informative to discuss the distribution of $C$. ornatus with respect to $C$. m. nigrescens. Tanner (1985) suggested that $C$. m. molossus occurs through most of Chihuahua, and that a wide area of intergradation with C.m. 
nigrescens occurs in northern Durango and southern Chihuahua. Possible C. m. molossus $\mathrm{x}$ nigrescens hybrids reported from northeastern Durango near the town of Pedriceña (Fouquette and Rossman 1963) and southwest Chihuahua, near Samachique (Gloyd 1940) seem to support this. Conversely, Klauber (1972) indicated the presence of C. m. nigrescens in central Chihuahua and proposed a zone of intergradation along the entire southern boundary of $C . m$. molossus. Likewise, Campbell and Lamar (2004) indicated a substantial incursion of C. $m$. nigrescens into west-central Chihuahua, but did not discuss introgression. Three specimens, (UTA R 17837-38 and UTEP 3052) seem to extend the range of C. m. nigrescens to the Sierra del Nido, approximately $75 \mathrm{~km}$ northwest of Ciudad Chihuahua. The Sierra Madre Occidental and Oriental are well known corridors for dispersal from southern Mexico, and the presence of C. m. nigrescens in the Sierra Madre of central Chihuahua is not unexpected. Unfortunately, the lack of taxonomic attention received by the $C$. molossus group has resulted in a failure to recognize distinct species and a subsequent lack of resolution with regard to geographic distribution of distinct lineages. Further sampling through central and southern Chihuahua is needed to accurately define the geographic distributions of lineages within the $C$. molossus group.

Extensive sampling from localities throughout the range of the black-tailed rattlesnake in the United States has allowed a much clearer biogeographical picture of Crotalus ornatus north of Mexico. The mountain ranges associated with the southeastern Colorado Plateau in New Mexico represent the northwestern limits of the lineage. From there, it is distributed throughout the mountain ranges of southern New Mexico and western Texas. In the United States, $C$. ornatus occupies two of the biotic provinces recognized by Blair (1949), the Chihuahuan and the Balconian. The Chihuahuan province is characterized by the basin-and-range topography that is 
typical of the northern Chihuahuan Desert, and encompasses south-central New Mexico, Texas (west of the Pecos River), eastern Chihuahua and central Coahuila, Mexico. The Edwards Plateau or Balcones Escarpment of central Texas defines the Balconian province (Werler and Dixon 2000). The eastern boundary of the species extends out of the Chihuahuan province to include the limestone canyons of the southern and eastern Edwards Plateau (Werler and Dixon 2000; Campbell and Lamar 2004). Populations on the Edwards Plateau are apparently disjunct from the populations of the adjacent Stockton Plateau and Chihuahuan province (Werler and Dixon 2000; Campbell and Lamar 2004). Werler and Dixon (2000) illustrated this disjunction in Texas populations between the Devils River of central Val Verde County and the vicinity of Rock Springs in eastern Edwards County, a distance of approximately $75 \mathrm{~km}$.

Remarks.-Hallowell (1854) provided a vague account of the collection locality as "near Pecos River, N. W. Texas" for the holotype. However, PC analysis of meristic data placed the holotype near specimens from the Beach and Baylor Mountains of Culberson Co., Texas. This could fit the general location given by Hallowell. McDiarmid et al. (1999) cited the locality as "between El Paso and San Antonio, Pecos River, Texas"; this differs from the original description and restricts the locality to somewhere on the Pecos River in Texas as opposed to the subjective reference of proximity to the Pecos River given by Hallowell. If USNM 486 were collected from a locality on the Pecos River, the type locality could be restricted to five counties (Crane, Crocket, Pecos, Terrell and Val Verde), which lie within the distribution of C. ornatus and border the Pecos River in Texas (Werler and Dixon 2000; Campbell and Lamar 2004).

The specimen is preserved as a skin with the head and tail attached, and the overall condition of the specimen is fair. However, several characters could not be confidently assessed. Examination of the dorsal pattern revealed 20 dorsal blotches before the pattern was lost to 
fading on the posterior $1 / 4$ of the body. The original description reported 17 blotches, but this did not include the seven fused anterior dorsal blotches. Damage to scales on the head prevented accurate measurement of upper and lower preoculars, supraoculars and prefrontals. Damage to the supraoculars makes it difficult to determine if the upper loreal makes partial contact with the frontal. Because of distortion of the head and skin around the eye, the postoculars, suboculars and interoculabials could not be assessed. The condition of the head suggests that it has been laterally compressed or had become dehydrated after preservation, causing disproportionate lateral shrinkage. Given the method of preservation of the specimen and the measurements reported by Hallowell (1854), a confident measurement of SVL could not be obtained. However, estimates of SVL (based on ratios of TL to SVL and HL to SVL) range from 74-100 $\mathrm{cm}$ for the specimen. The $26 \mathrm{~cm}$ discrepancy among estimates seems to be the result of the specimen's exceptionally short tail, only $4.9 \%$ of the SVL calculated from the measurements provided in Hallowell (1854) (5.2\% if Hallowell's measurement of body length included the tail) compared to $6.5 \%$ calculated from specimens examined in the present study. Based on my examination of the specimen, I am confident in designating the specimen as an adult female with a SVL greater than $80 \mathrm{~cm}$. 


\section{CHAPTER 4: DisCUSSION}

\subsection{Phylogeny and taXonomic status of CROTAlus molossus}

To date, this thesis represents the most comprehensive phylogenetic analysis of any member of the Crotalus molossus group. Five major lineages associated with the C. molossus group were recovered (C. m. nigrescens, C. basiliscus, C. totonacus, eastern C. m. molossus [recognized herein as C. ornatus] and western C. m. molossus [C. molossus sensu stricto]). Crotalus ornatus is confined to the vicinity of the northern Chihuahuan desert, occupying a region from south-central New Mexico through south-central Texas and adjacent Mexican states, whereas $C$. molossus sensu stricto occupies a range that is roughly equivalent to the Sonoran Desert east of the Colorado River. Despite the presence of both lineages in the southern ranges of the Rocky Mountains and the Madrean Archipelago, these two lineages are not sister taxa and do not seem to have been in contact with one another since their initial divergence 4.63 mya. The phylogenetic patterns recovered herein corroborate the polyphyly of C. m. molossus recovered by Wüster et al. (2005).

The well-supported and geographically defined lineages inferred herein demonstrate discordance between the current taxonomy of the Crotalus molossus group and its true diversity. Since the initial description of C. molossus by Baird and Girard (1853), only two authors have attempted to reclassify the species. Garman (1884) attempted to reclassify C. molossus as a variant of $C$. basiliscus, and Boulenger (1896) assigned the name C. terrificus to a group of rattlesnakes ( $C$. basiliscus, $C$. durissus and $C$. molossus); most recently the epithet terrificus has been associated with a lineage of $C$. durissus (C. d. terrificus, Laurenti 1768) occurring in southern and western Brazil, Bolivia, extreme southeastern Peru, Paraguay, Uruguay and 
Argentina (Campbell and Lamar 2004). Only one species (C. ornatus, Hallowell 1854) has been synonymized with C. molossus. Hallowell (1854) described Crotalus ornatus from USNM 486, a specimen collected near the Pecos River in Texas. Hallowell gives no further locality data, but any locality in the state of Texas will unequivocally lie within the distribution of the eastern lineage of C. m. molossus inferred in this study. Additionally, Hallowell's description is consistent with character states exhibited by the eastern lineage of C.m. molossus.

I prefer not to formally propose reclassification of the lineages $C$. m. nigrescens and $C$. m. oaxacus, as no specimens of the latter and only two specimens of the former lineage were available for molecular analyses. However, C. m. nigrescens is consistently inferred as the basal member of a group that includes $C$. basiliscus, $C$. totonacus and the remaining $C$. molossus group. It is logical that the subspecific epithet nigrescens will be elevated to full species and applied to all representatives of C. molossus occurring south of $\sim 25^{\circ} \mathrm{N}$ latitude. Additionally, some morphological overlap exists between specimens designated as C. m. nigrescens, $C$. molossus sensu stricto and C. ornatus. However, this overlap may be the result of failure to identify intergrades or properly assign specimens. In his description of C. m. nigrescens, Gloyd (1936) discussed a number of characters (not examined in the present study) that seem to hold true for this lineage, including head coloration and the extent of dark pigmentation anterior to the vent. The true phylogenetic position of C.m. oaxacus was not examined in the present study and remains poorly understood. Wüster et al. (2005) recovered $C$. m. oaxacus as sister to a clade containing C. basiliscus and C. molossus sensu stricto with weak support, and Campbell and Lamar (1989) attributed previous taxonomic confusion to plesiomorphic characters that C. m. oaxacus shares with $C$. basiliscus. Extensive sampling throughout the range of $C$. molossus sensu lato is needed to clearly define geographical boundaries and assess its diversity. 


\subsection{BIOGEOGRAPHY OF CROTALUS MOLOSSUS AND CROTALUS ORNATUS}

Phylogenetic analyses of the mtDNA and six-gene datasets have revealed biogeographic structure, with three well-supported clades in the eastern lineage (Fig. 3.1.1). The two specimens representing the apparently disjunct Edwards Plateau population (UTEP 17515 and 17520) are grouped with strong support in all analyses, but they are nested within the Stockton clade, which is strongly supported as the sister group to the Big Bend clade. Within the Big Bend clade, specimens from the western and northern Big Bend region (northern Brewster Co., central Presidio Co. and Jeff Davis Co., Texas) are grouped with strong support. A genetic divergence of $1.2 \%$ corresponding to an estimated divergence date of 0.73 mya was identified between specimens from the Bigbend clade and those occurring at the Indio Mountains Research Station (IMRS), a lower elevation extension of the Eagle Mountains in extreme southeastern Hudspeth Co., Texas. This suggests the area between these localities may represent a previously unaddressed barrier between populations of montane and semi-montane species. IMRS is separated from the Bigbend specimens by a swath of desert grassland stretching from the New Mexico border near Dell City, Texas through the towns of Van Horn and Marfa, Texas to the south. South of Van Horn, in western Jeff Davis Co. and north-central Presidio Co., the grassland becomes a wide valley bordered by the Sierra Vieja and Van Horn mountains to the west. East of these mountain ranges, the arid grassland (the Marfa Plains) gains slightly in elevation over $30 \mathrm{~km}$, before reaching the Davis Mountains. The Marfa Plains continue southeast from the town of Marfa, slightly past the Brewster County line. While not particularly low in elevation, the Marfa Plains are 400-600 m lower than the adjacent mountain ranges and offer no obvious refuge for dispersing montane species. In central Presidio County, a chain of 
disjunct mountain ranges funnels the arid grassland into a few narrow corridors that connect to the Presidio and Redford Bolsons. These adjoining bolsons form a low valley more than $25 \mathrm{~km}$ wide, which follows the Rio Grande for about $100 \mathrm{~km}$ from the town of Candeleria, Texas to the foothills south of the Bofecillos Mountains (Mraz and Keller 1980). Together, the Marfa Plains and Presidio Bolson seem to represent a recent biogeographic barrier for C. ornatus.

Crotalus molossus sensu stricto seems to reach its southern boundary near the Yaqui River (at about $28^{\circ} \mathrm{N}$ latitude) in the state of Sonora, Mexico. From there, the lineage occurs through the Sonoran Desert. Specimens examined from Isla Tiburón, off the central coast of Sonora, Mexico, are characteristic of specimens inferred in the western lineage by phylogenetic analyses. Morphological and molecular data indicate that populations from the Sierra San Luis of northwestern Chihuahua, Mexico and the Madrean Archipelago of southwestern New Mexico represent the eastern boundary of the lineage. Presumably, C. molossus sensu stricto is present through the Sierra Madre Occidental south of the Sierra San Luis from extreme western Chihuahua through most of Sonora, Mexico.

Geographic structure is evident among populations of southeastern Arizona and southwestern New Mexico (Madrean clade) and west-central Arizona (Sonoran clade); the basal divergence among these clades occurred near the Pliocene-Pleistocene boundary $\sim 1.86$ mya and is represented by marked genetic divergence (3.6\%). The estimated divergence date is consistent with the argument by Philips and Comus (2000), who suggested that patterns of diversity and endemism among Sonoran Desert plant assemblages indicated the formation of the Sonoran Desert at the Pliocene-Pleistocene boundary. Furthermore, this timescale is similar to that inferred by Douglas et al. (2010) for the basal diversification within the Gila monster (Heloderma suspectum). Niche conservatism and the likely origin of the C. molossus group in 
the subtropical Sierra Madre Occidental (implied by the current distribution of the basal lineage of the group) of the late Miocene may have resulted in biogeographic patterns triggered by the onset of aridification in the Sonoran Desert at the Pliocene-Pleistocene boundary. However, only two samples from the Sonoran clade were included in this study, and there are no available samples representing populations between the Sonoran and Madrean clades. In contrast, the Madrean clade is well represented by samples from the mountains of southeastern Arizona and southwestern New Mexico. The basal divergence in this clade is estimated at the midPleistocene ( $\sim 0.31$ mya), a common pattern within species occurring near the Cochise Filter Barrier (see examples below).

\subsection{The CROTALUS Molossus GROUP AT THE COCHISE FILTER BARRIER}

A narrow desert corridor that allows the exchange of taxa between the Sonoran and Chihuahuan deserts defines the Cochise Filter Barrier (CFB). The specific physical barrier of the CFB is poorly defined and lacks any geographical features that could be construed as an impediment to dispersal. Consequently, the term is generally applied to the lower elevation passes over the Western Continental Divide in southwestern New Mexico (Riddle and Hafner 2006; Castoe et al. 2007; Pyron and Burbrink 2010). Some authors (e.g., Riddle and Hafner 2006; Wilson and Pitts 2010a) have treated the CFB as a region encompassing a relatively large area comprised of the Madrean Archipelago of southeastern Arizona and the Deming Plains, which is a swath of desert grassland extending from the Arizona-New Mexico border to the Rio Grande in southern New Mexico. This approach may be more appropriate given the prevalence of lineage spillover; approximately 33\% of taxa examined by Pyron and Burbrink (2010) had representatives on both sides of the Western Continental Divide. Furthermore, many of the taxa 
with divergences that could be associated with the CFB have ranges that are not constrained by the Western Continental Divide, but they remain in the vicinity of the CFB (e.g., Jaeger et al. 2005; Castoe et al. 2007; Mulcahy 2007).

In this region, Crotalus ornatus is present in the Cook's Range, the Mimbres Mountains, and the eastern slopes of the Black Range in south-central New Mexico. Crotalus molossus sensu stricto is present in the Madrean Archipelago of southwestern New Mexico, the Mogollon Mountains and the Pinos Altos Range north of the Deming Plains. The wide swaths of desert grassland that currently provide corridors between Sonoran and Chihuahuan habitats likely prevent dispersal between many of the mountain ranges occupied by $C$. molossus and $C$. ornatus in this region. However, mountain ranges that define the northern border of the Deming plains (Mogollon, Pinos Altos, Mimbres and Black Range) seem relatively well connected and might allow contact between lineages. In this region, the Mimbres River and western continental divide north of the Mimbres Valley seem to represent the only potential barrier that may explain the apparent lack of introgression between $C$. ornatus and $C$. molossus.

Following the last major glaciation of North America, the CFB and associated region began a period of aridification, resulting in a transformation from mesic woodlands to the modern desert grassland habitat (Morafka 1977). Similar climatic events have occurred across the CFB following each major North American glaciation and a number of taxa underwent recent divergences at the CFB that may be attributable to these events (e.g., Callipepla, Zink and Blackwell 1998; Crotalus atrox, Castoe et al. 2007; Sceloporus magister complex, Leaché and Mulcahy 2007; Lampropeltis getula complex, Pyron and Burbrink 2009). Presumably, these divergences are the result of aridification beginning at the Pliocene-Pleistocene boundary and subsequent Pleistocene glaciation events forced desert-adapted taxa into refugia on either side of 
the CFB (Pyron and Burbrink 2010). This hypothesis fits desert-adapted species well and Pleistocene refugia are a likely explanation for post-Pliocene lineage divergence in the region. However, at least two recent studies have demonstrated deeper divergences and species boundaries at the CFB (e.g., Hypsiglena torquata species complex, Mulcahy 2008; Dilophotopsis sp., Wilson and Pitts 2010b). These relatively deep divergences are more likely the result of orogenic activity of the Sierra Madre Occidental and Rocky Mountains, which peaked in the mid- to late Miocene (Morafka 1977; Wilson and Pitts 2010a). Some authors have suggested that Neogene uplift of the area was minor and that the deep divergences reported for these taxa are the result of glaciation events occurring as early as 9 mya (see Wilson and Pitts 2010a and references therein). Regardless, the C. molossus group exhibits a deep divergence that seems to correspond well to the CFB and the Western Continental Divide. Indeed, the estimated mean divergence date of 4.63 mya between eastern and western C. m. molossus lineages (inclusive of their respective sister taxa $C$. basiliscus and $C$. totonacus) supports the idea of a Neogene vicariance event at the Sierra Madre Occidental.

\subsection{INTROGRESSION AND INCOMPLETE LINEAGE SORTING}

Hybridization is a common event among rattlesnakes, and Crotalus molossus is no exception. This study revealed a hybrid event between C. atrox and C. molossus sensu stricto (Figs. 3.1.1 and 3.1.2); the specimen (Mad 7, UTEP 20155) was collected in the town of Bayard, New Mexico and has no morphological characteristics distinguishing it as C. atrox. However, analyses of the mtDNA and six-gene datasets inferred this specimen as C. atrox, whereas analysis of the combined nDNA dataset recovered it as C. molossus sensu stricto. Several accounts describe hybridization between members of the C. molossus group and allies, including 
C.m. molossus x C.m.nigrescens (Gloyd 1940; Fouquette and Rossman 1963; Tanner 1985), C. molossus x C. basiliscus and C. molossus x C. totonacus (Campbell and Lamar 2004). The black-tailed rattlesnake is a montane generalist and is largely considered to be a semi-montane species, but specimens have been recorded from sand dunes and creosote flats (Armstrong and Murphy 1979; Beck 1991), suggesting that members of the C. molossus group are capable of dispersing between populations, which are usually associated with mountains or foothills. At the CFB, there are no distinct features that would prevent contact between C. molossus sensu stricto and C. ornatus, and it would not be unexpected to find patterns of mitochondrial introgression similar to that reported between Sceloporus cowlesi and S. tristichus (Leaché 2009). These nonsister mtDNA lineages of the $S$. undulatus species group seem to occupy generally similar habitats in adjacent ranges. In this case, the latter author sampled a known hybrid zone and was able to demonstrate discordance between the mtDNA data and his multi-locus nuclear dataset that was attributed to introgression. Although there seems to be a propensity for introgression in the C. molossus group, as recorded herein between C. atrox and C. molossus sensu stricto and by previous studies, mtDNA introgression was not evident between my samples of $C$. ornatus and C. molossus sensu stricto.

Independent analyses of the nuclear loci included in this study revealed extensive incomplete lineage sorting in the genus Crotalus. In general, introgression and incomplete lineage sorting can be readily distinguished by the pattern of incongruence. In most cases of introgression, the incongruence among lineages occurs at geographic clade boundaries (e.g., Leaché 2009). Incongruence resulting from incomplete lineage sorting is usually stochastic with respect to phylogeographic and taxonomic boundaries (McGuire et al. 2007). Results inferred from the EXPH5 dataset (Fig. 3.1.4) illustrated random placement of Crotalus specimens, 
indicating the presence of shared ancestral polymorphisms. This is not uncommon, especially among lineages that are weakly supported or have undergone rapid diversification (Wiens 2010a). In general, the New World Crotalinae is noted for its rapid diversification beginning $17-$ $22 \mathrm{Ma}$, ultimately resulting in $\sim 117$ extant species (Castoe et al. 2009; Wüster et al. 2008); this presents a speciation interval roughly half that of the Viperidae as a whole (Wüster et al. 2008). The handful of studies that have utilized nDNA markers to investigate relationships among pitvipers have used introns to address large-scale relationships among Asian species and questions regarding the sister taxon to the American Crotalinae (e.g., Creer et al. 2003, 2005, 2006; Malhotra et al. 2010). These studies did not indicate incongruence among trees inferred from nuclear intron datasets. Recently Kubatko et al. (2011) employed a dataset of 18 nuclear introns to examine relationships within the genus Sistrurus; the authors recovered a weak phylogenetic signal (similar to the nuclear genes used herein) from some of the nuclear loci that they examined, whereas others provided a phylogenetic signal similar to mitochondrial markers. It is likely that the inherent selective pressures and rate heterogeneity associated with portions of the coding genes examined herein have not allowed lineage sorting among the rattlesnakes to reach completion.

\subsection{CONCLUSIONS AND FUTURE DIRECTIONS}

This study revealed that the diversity of Crotalus molossus has been underestimated for over 150 years. Five lineages were recovered in association with the $C$. molossus group. Three were previously assigned to $C$. molossus and one of these had no current taxonomic recognition. Diversification within the C. molossus group seems to be associated with the uplift of the Sierra Madre Occidental beginning in the late Miocene and continuing to the Pliocene. The resulting 
lineages are well-supported in the inferred phylogenies and should be recognized as discrete taxonomic entities under the oldest available name. The western lineage should retain the present taxonomic designation Crotalus molossus. The previously synonymized name Crotalus ornatus is resurrected for the eastern lineage. Further study is needed for the currently recognized subspecies C.m.nigrescens and C.m.oaxacus.

The results of this study raise several questions regarding the diversity of the Crotalus molossus group. Future effort should be focused on defining the phylogeographic boundaries throughout Mexico. Moreover, sampling populations throughout Mexico for molecular analyses will open the door to answer questions that this study could not. For example, the phylogenetic relationship between $C$. basiliscus, C.m.nigrescens and C. m. oaxacus is still poorly defined. A greater sample size will provide better resolution for these relationships and will allow future researchers to investigate the evolutionary processes that have shaped the C. molossus group. In addition to phylogenetic work, an exhaustive analysis of morphometric, meristic, qualitative and hemipenial characters of the entire C.molossus group and it allies is needed. 


\section{LiterATURE Cited}

Alvarado-Díaz, J., and J. A. Campbell. 2004. A new montane rattlesnake (Viperidae) from Michoacán, Mexico. Herpetologica 60:281-286.

Arévalo, E., S. K. Davis, and J. W. Sites, Jr. 1994. Mitochondrial DNA sequence divergence and phylogenetic relationships among eight chromosome races of the Sceloporus grammicus complex (Phrynosomatidae) in central Mexico. Systematic Biology 43:387418.

Armstrong, B. L., and J. B. Murphy. 1979. The natural history of Mexican rattlesnakes. Special Publication of the Museum of Natural History, University of Kansas, No. 5.

Ashton, K. G., and A. de Queiroz. 2001. Molecular systematics of the western rattlesnake, Crotalus viridis (Viperidae), with comments on the utility of the D-Loop in phylogenetic studies of snakes. Molecular Phylogenetics and Evolution 21:176-189.

Avise, J. C., J. Arnold, R. M. Ball, E. Bermingham, T. Lamb, J. E. Neigel, C. A. Reeb, and N. C. Saunders. 1987. Intraspecific phylogeography: The mitochondrial DNA bridge between population genetics and systematics. Annual Review of Ecology and Systematics $18: 489-522$.

Baker, R. H. 1956. Mammals of Coahuila, Mexico. University of Kansas Publications, Museum of Natural History 9:125-335.

Baird, S. F., and C. Girard. 1853. Catalogue of North American reptiles in the museum of the Smithsonian Institution. Part I-Serpents. GPO, Washington, D.C.

Bandelt, H. J., P. Forster, and A. Röhl. 1999. Median-joining networks for inferring intraspecific phylogenies. Molecular Biology and Evolution 16:37-48. 
Beaman, K. R., and W. K. Hayes. 2008. Rattlesnakes: Research trends and annotated checklist. Pp. 5-16. In W.K. Hayes, K.R. Beaman, M.D. Cardwell, and S.P. Bush (Eds.), The Biology of the Rattlesnakes. Loma Linda University Press, Loma Linda, California, USA.

Beaupre, S. J. 1993. An ecological study of oxygen consumption in the mottled rock rattlesnake, Crotalus lepidus lepidus, and the black-tailed rattlesnake, Crotalus molossus molossus, from two populations. Physiological Zoology 66:437-454.

Beck, D. D. 1991. Physiological and behavioral consequences of reptilian life in the slow lane: Ecology of beaded lizards and rattlesnakes. Ph.D. Diss. University of Arizona, Tucson, Arizona, USA.

Beck, D. D. 1995. Ecology and energetics of three sympatric rattlesnake species in the Sonoran Desert. Journal of Herpetology 29:211-223.

Blair, W. F. 1949. The biotic provinces of Texas. Texas Journal of Science 2:93-117.

Boulenger, G. A. 1896. Catalogue of Snakes in the British Museum. Vol. 3. Taylor \& Francis, London, UK.

Brandley, M. C., A. Schmitz, and T. W. Reeder. 2005. Partitioned Bayesian analyses, partition choice, and the phylogenetic relationships of scincid lizards. Systematic Biology 54:373390.

Brandley, M. C., Y. Wang, X. Guo, A. N. Montes de Oca, M. Feria-Ortiz, T. Hikida, and H. Ota. 2011. Accommodating heterogeneous rates of evolution in molecular divergence dating methods: An example using intercontinental dispersal of Plestiodon (Eumeces) lizards. Systematic Biology 60:3-15.

Bryson Jr., R. W., R. W. Murphy, A. L. Lathrop, and D. L. Lazcano-Villareal. 2011. 
Evolutionary drivers of phylogeographical diversity in the highlands of Mexico: A case study of the Crotalus triseriatus species group of montane rattlesnakes. Journal of Biogeography 38:697-710.

Burbrink, F. T., and R. Lawson. 2007. How and when did Old World rat snakes disperse into the New World? Molecular Phylogenetics and Evolution 43:173-189.

Burbrink, F. T., F. Fontanella, R. A. Pyron, T. J. Guiher, and C. Jimenez. 2008. Phylogeography across a continent: The evolutionary and demographic history of the North American racer (Serpentes: Colubridae: Coluber constrictor). Molecular Phylogenetics and Evolution 47:274-288.

Campbell, J. A., and O. Flores-Villela. 2008. A new long-tailed rattlesnake (Viperidae) from Guerrero, Mexico. Herpetologica 64:246-257.

Campbell, J. A., and W. L. Lamar. 1989. The Venomous Reptiles of Latin America. Cornell University Press, Ithaca, New York, USA.

Campbell, J. A., and W. L. Lamar. 2004. The Venomous Reptiles of the Western Hemisphere. Cornell University Press, Ithaca, New York, USA.

Castoe, T. A., and C. L. Parkinson. 2006. Bayesian mixed models and the phylogeny of pitvipers (Viperidae: Serpentes). Molecular Phylogenetics and Evolution 39:91-110.

Castoe, T. A., C. L. Spencer, and C. L. Parkinson. 2007. Phylogeographic structure and historical demography of the western diamondback rattlesnake (Crotalus atrox): A perspective on North American desert biogeography. Molecular Phylogenetics and Evolution 42:193212.

Castoe, T. A., J. M. Daza, E. N. Smith, M. M. Sasa, U. Kuch, J. A. Campbell, P. T. Chippindale, and C. L. Parkinson. 2009. Comparative phylogeography of pitvipers suggests a 
consensus of ancient Middle American highland biogeography. Journal of Biogeography $36: 88-103$.

Chen, T., and E. D. Real. 1997. Purification of M5, a fibrinolytic proteinase from Crotalus molossus molossus venom that attacks complement. The International Journal of Biochemistry and Cell Biology 29:789-799.

Collins, J. T. 1991. Viewpoint: A new taxonomic arrangement for some North American reptiles and amphibians. Herpetological Review 22:42-43.

Collins, J. T., and T. W. Taggart. 2009. Standard common and current scientific names for North American amphibians, turtles, reptiles, and crocodilians. Sixth edition. The Center for North American Herpetology, Lawrence, Kansas, USA.

Conant, R. 1963. Semiaquatic snakes of the genus Thamnophis from the isolated drainage system of the Rio Nazas and adjacent areas in Mexico. Copeia 1963:473-499.

Creer, S., A. Malhotra, and R. S. Thorpe. 2003. Assessing the phylogenetic utility of four mitochondrial genes and a nuclear intron in the Asian pit viper genus Trimeresurus: separate, simultaneous, and conditional data combination analyses. Molecular Biology and Evolution 20:1240-1251.

Creer, S., A. Malhotra, R. S. Thorpe, and C. E. Pook. 2005. Targeting optimal introns for phylogenetic analyses in non-model taxa: Experimental results in Asian pitvipers. Cladistics 21:390-395.

Creer, S., C. E. Pook, A. Malhotra, and R. S. Thorpe. 2006. Optimal intron analyses in the Trimeresurus radiation of Asian pitvipers. Systematic Biology 55:57-72.

Degenhardt, W. G., C. W. Painter, and A. H. Price. 1996. Amphibians and Reptiles of New Mexico. University of New Mexico Press, Albuquerque, New Mexico, USA. 
de Queiroz, K. 1998. The general lineage concept of species, species criteria, and the process of speciation. Pp. 57-75. In D. J. Howard, and S. H. Berlocher (Eds.), Endless forms: Species and speciation. Oxford University Press, New York, USA.

de Queiroz, K. 1999. The general lineage concept of species and the defining properties of the species category. Pp. 49-89. In R. A. Wilson (Ed.), Species: New interdisciplinary essays. Massachusetts Institute of Technology Press, Cambridge, Massachusetts, USA.

Devitt, T. J., T. J. LaDuc, and J. A. McGuire. 2008. The Trimorphodon biscutatus (Squamata: Colubridae) species complex revisited: A multivariate statistical analysis of geographic variation. Copeia 2008:370-387.

Douglas M. E., M. R. Douglas, G. W. Schuett, L. W. Porras, and A. T. Holycross. 2002. Phylogeography of the western rattlesnake (Crotalus viridis) complex, with emphasis on the Colorado Plateau. Pp. 11-50. In G.W. Schuett, M. Höggren, M.E. Douglas, H.W. Greene (Eds.), Biology of the Vipers. Eagle Mountain Publishing, Eagle Mountain, Utah, USA.

Douglas, M. E., M. R. Douglas, G. W. Schuett, and L. W. Porras. 2006. Evolution of rattlesnakes (Viperidae; Crotalus) in the warm deserts of western North America shaped by Neogene vicariance and Quaternary climate change. Molecular Ecology 15:3353-3374.

Douglas, M. E., M. R. Douglas, G. W. Schuett, L. W. Porras, and B. L. Thomason. 2007. Genealogical concordance between mitochondrial and nuclear DNAs supports species recognition of the Panamint rattlesnake (Crotalus mitchellii stephensi). Copeia 2007:920932.

Douglas, M. E., M. R. Douglas, G. W. Schuett, D. D. Beck, and B. K. Sullivan. 2010. 
Conservation phylogenetics of helodermatid lizards using multiple molecular markers and a supertree approach. Molecular Phylogenetics and Evolution 55:153-167.

Dovc, P., and W. Hecht. 1995. Rapid Communication: Nucleotide sequence of caprine mitochondrial genes for tRNALys and two subunits of F0-ATPase. Journal of Animal Science 73:3493.

Dowling, H. G. 1951. A proposed standard system of counting ventrals in snakes. British Journal of Herpetology 1:97-99.

Drummond, A. J., and A. Rambaut. 2007. BEAST: Bayesian evolutionary analysis by sampling trees. BMC Evolutionary Biology 7:214.

Drummond, A. J., S. Y. W. Ho, M. J. Phillips, and A. Rambaut. 2006. Relaxed phylogenetics and dating with confidence. PLoS Biology 4:e88.

Excoffier, L. G., and H. E. L. Lischer. 2010. Arlequin suite version 3.5: A new series of programs to perform population genetics analyses under linex and windows. Molecular Ecology Resources 10:564-567.

Excoffier, L., P.E. Smouse, and J.M. Quattro. 1992. Analysis of molecular variance inferred from metric distances among DNA haplotypes: Application to human mitochondrial DNA restriction data. Genetics Society of America 131:479-491.

Felsenstein, J. 1985. Limits on phylogenies: An approach using the bootstrap. Evolution 39:783791.

Foote, R., and J. A. MacMahon. 1977. Electrophoretic studies of rattlesnake (Crotalus and Sistrurus) venom: Taxonomic implications. Comparative Biochemistry and Physiology Part B 57:235-241.

Fouquette Jr., M. J., and D. A. Rossman. 1963. Noteworthy records of Mexican amphibians and 
reptiles in the Florida state museum and the Texas natural history collection. Herpetologica 19:185-201.

Fu, Y. X. 1997. Statistical tests of neutrality of mutations against population growth, hitchhiking, and background selection. Genetics 147:915-925.

Garman, S. 1884. The North American reptiles and batrachians. A list of the species occurring north of the Isthmus of Tehuantepec, with references. Bulletin of the Essex Institute $16: 1-46$.

Gibbs, H. L., and J. Diaz. 2010. Identification of single copy nuclear DNA markers for North American pit vipers. Molecular Ecology Resources 10:177-180.

Gloyd, H. K. 1936. A Mexican subspecies of Crotalus molossus Baird and Girard. Occasional Papers of the Museum of Zoology. University of Michigan 325:1-5.

Gloyd, H. K. 1940. The rattlesnakes, genera Sistrurus and Crotalus. A study in zoogeography and evolution. Special Publication of the Chicago Academy of Sciences 4:1-270.

Gloyd, H. K. 1948. Description of a neglected subspecies of rattlesnake from Mexico. Chicago Academy of Sciences, Natural History Miscellanea 17:1-4.

Greenbaum, E. 2004. The influence of prey-scent stimuli on predatory behavior of the North American copperhead Agkistrodon contortrix (Serpentes: Viperidae). Behavioral Ecology $15: 345-350$.

Greene, H. W., P. May, D. L. Hardy Sr., J. Sciturro, and T. Farrell. 2002. Parental behavior by vipers. Pp. 179-205. In G. W. Schuett, M. HoÅNggren, M. E. Douglas, and H. W. Greene (Eds.), Biology of the Vipers. Eagle Mountain Publishing, Eagle Mountain, Utah, USA.

Grismer, L. L. 1999. An evolutionary classification of reptiles on islands in the Gulf of California, Mexico. Herpetologica 55:446-469. 
Groombridge, G. 1986. Phylogenetic relationships among viperine snakes. Pp. 219-222. In Z. Rocek (Ed.), Studies in herpetology: Proceedings of the European herpetological meeting $\left(3^{\text {rd }}\right.$ ordinary general meeting of the Societas Europea Herpetologica), Charles University, Prague.

Gutberlet Jr., R. L., and M. B. Harvey. 2004. The evolution of new world venomous snakes. Pp. 634-682. In J. A. Campbell and W. W. Lamar (Eds.) The Venomous Reptiles of the Western Hemisphere Vol. II, Cornell University Press, Ithaca, New York, USA.

Hafner, D. J., M. S. Hafner, G. L. Hasty, T. A. Spradling, and J.W. Demastes. 2008. Evolutionary relationships of pocket gophers (Craogeomys castanops species group) of the Mexican altiplano. Journal of Mammology 89:190-208.

Hallowell, E. 1854. Descriptions of new reptiles from California. Proceedings of the Academy of Natural Sciences, Philadelphia 7:91-97.

Harpending, H. C. 1994. Signature of ancient population growth in a low-resolution mitochondrial DNA mismatch distribution. Human Biology 66:591-600.

Harpending, H. C., M. A. Batzer, M. Gurven, L. B. Jorde, and S. T. Sherry. 1998. Genetic traces of ancient demography. Proceedings of the National Academy of Sciences 95:1961-1967.

Holman, J. A. 2000. Fossil Snakes of North America: Origin, Evolution, Distribution, Paleoecology. Indiana University Press, Indianapolis, Indiana, USA.

Hoser, R. 1998. Death adders (genus Acanthophis): An overview, including descriptions of five new species and one subspecies. Monitor 9:20-30, 33-41.

Hoser, R. 2009a. A reclassification of the rattlesnakes; species formerly exclusively referred to the genera Crotalus and Sistrurus. Australian Journal of Herpetology 6:1-21. 
Hoser, R. 2009b. Reclassification of the cobras; species formerly referred to the genera Naja, Boulengerina, and Paranaja. Australian Journal of Herpetology 7:1-15.

Hoser, R. 2009c. Creationism and contrived science: A review of recent python systematics papers and the resolution of issues of taxonomy and nomenclature. Australasian Journal of Herpetology 2:1-34.

Huelsenbeck, J. P., and F. Ronquist. 2001. MRBAYES: Bayesian inference of phylogeny. Bioinformatics 17:754-755.

Jaden, R. C., E. N. Smith, and J. A. Campbell. 2011. Unraveling a tangle of Mexican serpents: A systematic revision of highland pitvipers. Zoological Journal of the Linnean Society $163: 943-958$

Jaeger, J. R., B. R. Riddle, and D. F. Bradford. 2005. Cryptic Neogene vicariance and Quaternary dispersal of the red-spotted toad (Bufo punctatus): Insights on the evolution of North American warm desert biotas. Molecular Ecology 14:3033-3048.

Joseph, L., T. Wilke, E. Bermingham, D. Alpers, and R. Ricklefs. 2004. Towards a phylogenetic framework for the evolution of shakes, rattles, and rolls in Myiarchus tyrant-flycatchers (Aves: Passeriformes: Tyrannidae). Molecular Phylogenetics and Evolution 31:139-152.

Kardong, K. V. 1982. The evolution of the venom apparatus in snakes from colubrids to viperids to elapids. Memórias do Instituto Butantan 46:105-118.

Kelly, C. M. R., N. P. Barker, and M. H. Villet. 2003. Phylogenetics of advanced snakes (Caenophidia) based on four mitochondrial genes. Systematic Biology 52:439-459.

Klauber, L. M. 1949. Some new and revived subspecies of rattlesnakes. Transactions of the San Diego Society of Natural History 11:61-116.

Klauber, L. M. 1972. Rattlesnakes: Their Habits, Life Histories, and Influence on Mankind. 
Second Edition. University of California Press, Berkeley, California, USA.

Krutak, P. R. 1967. Structural geology of the Sierra de la Gavia, Coahuila, Mexico. Geological Society of America Bulletin 78:59-76.

Kubatko, L., H. L. Gibbs, and E. W. Bloomquist. 2011. Inferring species-level phylogenies and taxonomic distinctiveness using multi-locus data in Sistrurus rattlesnakes. Systematic Biology 60:393-409.

LaDuc, T. J., and J. D. Johnson. 2003. A taxonomic revision of Trimorphodon biscutatus vilkinsonii (Serpentes: Colubridae). Herpetologica 59:365-375.

Laurenti, J. N. 1768. Specimen medicum exhibens Synopsis Reptilium emendatum cum experimentis circa venena et antidota reptilium austiacorum. Joan. Thom. Trattnern, Vienna, Austria.

Lawson, R., J. B. Slowinski, B. I. Crother, and F. T. Burbrink. 2005. Phylogeny of the Colubroidea (Serpentes): New evidence from mitochondrial and nuclear genes. Molecular Phylogenetics and Evolution 37:581-601.

Leaché, A. D. 2009. Species tree discordance traces to phylogeographic clade boundaries in North American fence lizards (Sceloporus). Systematic Biology 58:547-559.

Leaché A. D., and D. G. Mulcahy. 2008. Phylogeny, divergence times and species limits of spiny lizards (Sceloporus magister species group) in western North American deserts and Baja California. Molecular Ecology 16:5216-5233.

Lemmon, A. R., and E. C. Moriarty. 2004. The importance of proper model assumption in Bayesian phylogenetics. Systematic Biology 53:265-277.

Lenk, P., S. Kalayabina, M. Wink, and U. Joger. 2001. Evolutionary relationships among the 
true vipers (Reptilia: Viperidae) inferred from mitochondrial DNA sequences. Molecular Phylogenetics and Evolution 19:94-104.

Leviton, A. E., R. H. Gibbs Jr., E. Heal, and C. E. Dawson. 1985. Standards in herpetology and ichthyology. Part 1. Standard symbolic codes for institutional resource collections in herpetology and ichthyology. Copeia 1985:802-832.

Liem, K. F., H. Marx, and G. B. Rabb. 1971. The viperid snake Azemiops: Its comparative cephalic anatomy and phylogenetic position in relation to Viperinae and Crotalinae. Fieldiana Zoology 59:65-126.

Lovette, I. J., E. Bermingham, S. Rohwer, and C. Wood. 1999. Mitochondrial restriction fragment length polymorphism (RFLP) and sequence variation among closely related avian species and the genetic characterization of hybrid Dendroica warblers. Molecular Ecology 8:1431-1441.

Maddison, D. R., and W. P. Maddison. 2000. MacClade 4: Analysis of phylogeny and character evolution version 4.0. Sinauer Associates, Sunderland, Massachusetts, USA.

Malhotra, A., S. Creer, C. E. Pook, and R. S. Thorpe. 2010. Inclusion of nuclear intron sequence data helps to identify the Asian sister group of New World pitvipers. Molecular Phylogenetics and Evolution 54:172-178.

McDiarmid, R. W., J. A. Campbell, and T. A. Touré. 1999. Snake Species of the World: A Taxonomic and Geographic Reference, Vol. 1. Herpetologists' League, Washington, D.C.

McGuire, J. A., C. W. Linkem, M. S. Koo, D. W. Hutchison, A. K. Lappin, D. I. Orange, J. 
Lemos-Espinal, B. R. Riddle, and J. R. Jaeger. 2007. Mitochondrial introgression and incomplete lineage sorting through space and time: Phylogenetics of crotaphytid lizards. Evolution 61:2879-2897.

Minton, S. A. 1992. Serologic relationships among pitvipers: Evidence from plasma albumins and immunodiffusion. Pp. 155-161. In J.A. Campbell and E.D. Brodie Jr. (Eds.), Biology of the Pitvipers. Selva, Tyler, Texas, USA.

Meik, J. M., and A. Pires-daSilva. 2009. Evolutionary morphology of the rattlesnake style. BMC Evolutionary Biology 9:35.

Morafka, D. J. 1977. A Biogeographical Analysis of the Chihuahuan Desert Through its Herpetofauna. Dr. W. Junk Publishers, The Hague, Netherlands.

Mraz, J. R., and G. R. Keller. 1980. Structure of the Presidio bolson area, Texas, interpreted from gravity data. Geological Circular 80:13.

Mulcahy, D. G. 2008. Phylogeography and species boundaries of the western North American night snake (Hypsiglena torquata): Revisiting the subspecies concept. Molecular Phylogenetics and Evolution 46:1095-1115.

Murphy, R. W., J. Fu, A. Lathrop, J. V. Feltham, and V. Kovac. 2002. Phylogeny of the rattlesnakes (Crotalus and Sistrurus) inferred from sequences of five mitochondrial DNA genes. Pp. 69-92. In G.W. Schuett, M. Höggren, M.E. Douglas, and H.W. Green (Eds.), Biology of the Vipers. Eagle Mountain Publishing, Eagle Mountain, Utah, USA.

NOAA. 2004. The North American Monsoon. Reports to the Nation on our Changing Planet. NOAA/National Weather Service.

Norris, R. 2004. Venom poisoning by North American reptiles. Pp. 683-708. In J. A. Campbell and W. W. Lamar (Eds.), Venomous Reptiles of the Western Hemisphere. Cornell 
University Press, Ithaca, New York, USA.

Nylander, J. A. A, J. C. Wilgenbusch, D. L. Warren, and D. L. Swofford. 2008. AWTY (are we there yet?): A system for graphical exploration of MCMC convergence in Bayesian phylogenetics. Bioinformatics 24:581-583.

Parkinson, C. L. 1999. Molecular systematics and biological history of pitvipers as determined by mitochondrial ribosomal DNA sequences. Copeia 1999:576-586.

Parkinson, C. L., J. A. Campbell, and P. Chippindale. 2002. Multigene phylogenetic analysis of pitvipers, with comments on their biogeography. Pp. 93-110. In G.W. Schuett, M.

Höggren, M.E. Douglas, and H.W. Greene (Eds.), Biology of the Vipers. Eagle Mountain Publishing, Utah, USA.

Parmley, D., and J. A. Holman. 2007. Earliest fossil record of a pigmy rattlesnake (Viperidae: Sistrurus Garman). Journal of Herpetology 41:141-144.

Peterson, M. K. 1976. The Río Nazas as a factor in mammalian distribution in Durango, Mexico. The Southwestern Naturalist 20:495-502.

Phillips, S. J., and P. W. Comus. 2000. A Natural History of the Sonoran Desert. ArizonaSonoran Desert Museum Press, Tucson, Arizona, USA.

Place, A. J., and C. I. Abramson. 2004. A quantitative analysis of the ancestral area of rattlesnakes. Journal of Herpetology 38:152-156.

Pook, C. E., W. Wüster, and R. S. Thorpe. 2000. Historical biogeography of the western rattlesnake (Serpentes: Viperidae: Crotalus viridis), inferred from mitochondrial DNA sequence information. Molecular Phylogenetics and Evolution 15:269-282.

Pook, C. E., U. Joger, N. Stümpel, and W. Wüster. 2009. When continents collide: Phylogeny, historical biogeography and systematics of the medically important viper genus Echis 
(Squamata: Serpentes: Viperidae). Molecular Phylogenetics and Evolution 53:792-807.

Portik, D. M., A. M. Bauer, and T. R. Jackman. 2010. The phylogenetic affinities of Trachylepis sulcata nigra and the intraspecific evolution of coastal melanism in the western rock skink. African Zoology 45:147-159.

Portik, D. M., P. L. Wood Jr., J. L. Grismer, E. L. Stanley, and T. R. Jackman. 2011. Identification of 104 rapidly-evolving nuclear protein-coding markers for amplification across scaled reptiles using genomic resources. Conservation Genetics Resources.

Posada, D. 2008. jModelTest: Phylogenetic model averaging. Molecular Biology and Evolution 25:1253-1256.

Pyron, R. A., and F. T. Burbrink. 2009. Lineage diversification in a widespread species: Roles for niche divergence and conservatism in the common kingsnake, Lampropeltis getula. Molecular Ecology 18:3443-3457.

Pyron, R. A., and F. T. Burbrink. 2010. Hard and soft allopatry: Physically and ecologically mediated modes of geographic speciation. Journal of Biogeography 37:2005-2015.

Pyron, R. A., F. T. Burbrink, G. R. Colli, A. N. Montes de Oca, L. J. Vitt, C. A. Kuczynski, and J. J. Wiens. 2011. The phylogeny of advanced snakes (Colubroidea), with discovery of a new subfamily and comparison of support methods for likelihood trees. Molecular Phylogenetics and Evolution 58:329-342.

Quijada-Mascareñas, A., and W. Wüster. 2006. On the origins and dispersal of Neotropical rattlesnakes in South America. Canadian Association of Herpetologists Bulletin 14:6-12.

Rambaut A., and Drummond A. 2010. FigTree v1.3.1. Institute of Evolutionary Biology, University of Edinburgh, Edinburgh, UK.

Riddle, B. R., and D. J. Hafner. 2006. A Step-wise approach to integrating phylogeographic 
and phylogenetic biogeographic perspectives on the history of a core North American warm deserts biota. Journal of Arid Environments 66:435-461.

Rogers, A. R., and H. Harpending. 1992. Population growth makes waves in the distribution of pairwise genetic differences. Molecular Biology and Evolution 9:552-569.

Ronquist, F., and J. P. Huelsenbeck. 2003. MrBayes 3: Bayesian phylogenetic inference under mixed models. Bioinformatics 19:1572-1574.

Savage, J. M., J. A. Campbell, and W. W. Lamar. 2005. On the names for Neotropical rattlesnakes. Herpetological Review 36:369-371.

Scheutt G. W., and M. S. Grober. 2000. Post-fight levels of plasma lactate and corticosterone in male copperheads, Agkistrodon contortrix (Serpentes, Viperidae): Differences between winners and losers. Physiology and Behavior 71:335-341.

Shimodaira, H. 2002. An approximately unbiased test of phylogenetic tree selection. Systematic Biology 51:492-508.

Shimodaira, H., and M. Hasegawa. 2001. CONSEL: For assessing the confidence of phylogenetic tree selection. Bioinformatics 17:1246-1247.

Simpson, G. G. 1961. Principles of Animal Taxonomy. Columbia University Press, New York, USA.

Stamatakis, A. 2006. RAxML-VI-HPC: Maximum likelihood-based phylogenetic analyses with thousands of taxa and mixed models. Bioinformatics 22:2688-2690.

Stamatikis, A., F. Blagojevic, D. Nikolopoulos, and C. Antonopoulos. 2007. Exploring new search algorithms and hardware for phylogenetics; RAxML meets the IBM cell. Journal of VLSI Signal Processing 48:271-286.

Stamatikis, A., P. Hoover, and J. Rougemont. 2008. A rapid bootstrap algorithm for the RAxML 
web servers. Systematic Biology 57:758-771.

Swofford, D. L. 2002. PAUP*. Phylogenetic analysis using parsimony (*and other methods). Version 4.0b. Sinauer Associates, Sunderland, Massachusetts, USA.

Swindell, S. R., and T. N. Plasterer. 1997. SEQMAN: Contig assembly. Methods in Molecular Biology 70:75-89.

Tamura, K. J., D. M. Nie, and S. Kumar. 2007. MEGA4: Molecular Evolutionary Genetics Analysis (MEGA) software version 4.0. Molecular Biology and Evolution 24:1596-1599.

Tanner, W. W. 1985. Snakes of western Chihuahua. Great Basin Naturalist 45:615-676.

Vervust, B., S. Van Dongen, and R. Van Damme. 2009. The effect of preservation on lizard morphometrics - an experimental study. Amphibia-Reptilia 30:321-329

Vonk, F. J., J. F. Admiraal, K. Jackson, R. Reshef, M. A. G. De Bakker, K. Vanderschoot, I. Van den Berge, M. Van Atten, E. Burgerhout, A. Beck, P. J. Mirtschin, E. Kochva, F. Witte, B. G. Fry, A. E. Woods, and M. K. Richardson. 2008. Evolutionary origin and development of snake fangs. Nature 454:630-633

Wallach, V., W. Wüster, and D. G. Broadley. 2009. In praise of subgenera: Taxonomic status of cobras of the genus Naja Laurenti (Serpentes: Elapidae). Zootaxa 2236:26-36

Warrell, D. A. 2004. Snakebite in Central and South America: Epidemiology, clinical features, and clinical management. In J. A. Campbell and W. W. Lamar (Eds.), Venomous Reptiles of the Western Hemisphere. Cornell University Press, Ithaca, New York, USA.

Werler, J. E., and J. R. Dixon. 2000. Texas Snakes: Identification, Distribution and Natural History. University of Texas Press, Austin, Texas, USA.

Wiley, E. O. 1978. The evolutionary species concept reconsidered. Systematic Zoology 27:1726. 
Wiens, J. J. 1998. Combining data sets with different phylogenetic histories. Systematic Biology 47:568-581.

Wiens, J. J., 2003. Missing data, incomplete taxa, and phylogenetic accuracy. Systematic Biology 52:528-538.

Wiens, J. J., C. A. Kuczynski, S. A. Smith, D. G. Mulcahy, J. W. Sites Jr., T. M. Townsend, and T. W. Reeder. 2008. Branch lengths, support, and congruence: Testing the phylogenomic approach with 20 nuclear loci in snakes. Systematic Biology 57:420-431.

Weins, J. J., C. A. Kuczynski, and P. R. Stephens. 2010. Discordant mitochondrial and nuclear gene phylogenies in emydid turtles: Implications for speciation and conservation. Biological Journal of the Linnean Society 99:445-461.

Williams, D., W. Wüster, and B. G. Fry. 2006. The good, the bad and the ugly: Australian snake taxonomists and a history of the taxonomy of Australia's venomous snakes. Toxicon 48:919-930.

Wilson, J. S., and J. P. Pitts. 2010a. Illuminating the lack of consensus among descriptions of Earth history data in the North American deserts: A resource for biologists. Progress in Physical Geography 34:419-441.

Wilson, J. S., and J. P. Pitts. 2010b. Phylogeography of the nocturnal velvet ant genus Dilophotopsis (Hymenoptera: Mutillidae): Enhancing our understanding of diversification in the Nearctic desert biota. Biological Journal of the Linnean Society 101:360-375.

Wüster, W., B. Bush, J. S. Keogh, M. O’Shea, and R. Shine. 2001.Taxonomic contributions in the "'amateur' literature: Comments on recent descriptions of new genera and species by Raymond Hoser. Litteratura Serpentium 21:67-79, 86-91. 
Wüster, W., J. E. Ferguson, J. A. Quihada-Mascareñas, C. E. Pook, M. da Graça Salomoã, and R. S. Thorpe. 2005. Tracing an invasion: Landbridges, refugia, and the phylogeography of the Neotropical rattlesnake (Serpentes: Viperidae: Crotalus durissus). Molecular Ecology 14:1095-1108.

Wüster, W., L. Peppin, C. E. Pook, and D. E. Walker. 2008. A nesting of vipers: Phylogeny and historical biogeography of the Viperidae (Squamata: Serpentes). Molecular Phylogenetics and Evolution 49:445-459.

Zhang, M., D. Rao, J. Yang, G. Yu, and J. A. Wilkinson. 2010. Molecular phylogeography and population structure of a mid-elevation montane frog Leptobrachium ailaonicum in a fragmented habitat of southwest China. Molecular Phylogenetics and Evolution 54:4758.

Zink, R. M., and R. C. Blackwell. 1998. Molecular systematics of the scaled quail complex (Genus Callipepla). The Auk 115:394-403. 


\section{APPENDIX I}

Samples used for genetic analyses in this study with voucher information, locality data, and GenBank accession numbers. All sequences are novel to the present study unless otherwise indicated. Institutional codes follow Leviton et al. (1985); additional voucher codes are as follows: CGA $=$ C. G. Anderson field series; CLP $=$ C. L. Parkinson field series; JAC = J. A. Campbell field series; Moody = S. M. Moody. IMRS = Indio Mountains Research Station. Complete locality data are provided in Appendix II.

\begin{tabular}{|c|c|c|c|c|c|c|c|c|}
\hline Taxon and sample identifier & Voucher & Locality & \multicolumn{6}{|c|}{ GenBank Accession Numbers } \\
\hline & & & cyt $b$ & ND4 & $\begin{array}{l}\text { ATPases } \\
8 \text { and } 6\end{array}$ & c-mos & EXPH5 & RAG1 \\
\hline Agkistrodon contortrix & Moody 338 & USA, Ohio, Athens Co. & AY223612 & $\mathrm{AF} 156576^{\mathrm{a}}$ & - & - & - & - \\
\hline Agkistrodon piscivorus & CLP 30 & USA, South Carolina & AY223610 & AF156578 & - & - & - & - \\
\hline Crotalus adamanteus & UTEP 18472 & USA, Florida, Baker Co. & JN620809 & JN620959 & JN620850 & JN620891 & JN620927 & JN621000 \\
\hline Crotalus atrox 1 & UTEP 19051 & $\begin{array}{l}\text { USA, Arizona, Maricopa } \\
\text { Co. }\end{array}$ & JN620810 & JN620960 & JN620851 & JN620892 & JN620928 & JN621001 \\
\hline Crotalus atrox 2 & UTEP 19849 & USA, Texas, Brewster Co. & JN620811 & JN620961 & JN620852 & JN620893 & JN620929 & JN621002 \\
\hline Crotalus basiliscus & $822 *$ & Mexico, Nayarit, San Blas & AY704844 & AY70489 & - & - & - & - \\
\hline Crotalus cerastes & UTEP 19278 & USA, Arizona, La Paz Co. & JN620812 & JN620962 & JN620853 & JN620894 & JN620930 & JN621003 \\
\hline Crotalus cerberus & UTEP 19166 & USA, Arizona, Graham Co. & JN620813 & JN620963 & JN620854 & JN620895 & - & - \\
\hline Crotalus horridus & UTEP 19288 & USA, Texas, Montague Co. & JN620815 & JN620965 & JN620856 & JN620897 & JN620932 & JN621004 \\
\hline Crotalus lepidus & UTEP 19237 & USA, Texas, Presidio Co. & JN620816 & JN620966 & JN620857 & JN620898 & JN620933 & JN621005 \\
\hline Crotalus mitchellii & UTEP 17628 & $\begin{array}{l}\text { USA, California, Imperial } \\
\text { Co. }\end{array}$ & JN620817 & JN620967 & JN620858 & JN620899 & JN620934 & JN621006 \\
\hline Crotalus molossus (Son 1) & UTEP 18857 & $\begin{array}{l}\text { USA, Arizona, Yavapai } \\
\text { Co. }\end{array}$ & JN620843 & JN620993 & JN620884 & JN620922 & JN620954 & JN621028 \\
\hline Crotalus molossus (Son 2) & UTEP 19091 & $\begin{array}{l}\text { USA, Arizona, Maricopa } \\
\text { Co. }\end{array}$ & JN620845 & JN620995 & JN620886 & JN620924 & JN620956 & JN621030 \\
\hline
\end{tabular}




\begin{tabular}{|c|c|c|c|c|c|c|c|c|}
\hline Crotalus molossus (Mad 1) & UTEP 18881 & $\begin{array}{l}\text { USA, Arizona, Santa Cruz } \\
\text { Co., Canello Hills }\end{array}$ & JN620842 & JN620992 & JN620883 & JN620921 & JN620953 & JN621027 \\
\hline Crotalus molossus (Mad 2) & UTEP 18777 & $\begin{array}{l}\text { USA, Arizona, Santa Cruz } \\
\text { Co., Patagonia Mountains }\end{array}$ & JN620841 & JN620991 & JN620882 & JN620920 & JN620952 & JN621026 \\
\hline Crotalus molossus (Mad 3) & UTEP 20156 & $\begin{array}{l}\text { USA, New Mexico, Grant } \\
\text { Co., Big Burro Mountains }\end{array}$ & JN620826 & JN620976 & JN620867 & JN620908 & JN620942 & JN621015 \\
\hline Crotalus molossus (Mad 4) & UTEP 18561 & $\begin{array}{l}\text { USA, New Mexico, Grant } \\
\text { Co. }\end{array}$ & JN620837 & JN620987 & JN620878 & JN620916 & JN620948 & JN621022 \\
\hline Crotalus molossus (Mad 5) & CGA 08 & $\begin{array}{l}\text { USA, New Mexico, Grant } \\
\text { Co., Big Burro Mountains }\end{array}$ & JN620827 & JN620977 & JN620868 & - & - & - \\
\hline Crotalus molossus (Mad 6) & UTEP 19982 & $\begin{array}{l}\text { USA, New Mexico, Grant } \\
\text { Co., Pinos Altos Range }\end{array}$ & JN620840 & JN620990 & JN620881 & JN620919 & JN620951 & JN621025 \\
\hline Crotalus molossus (Mad 7) & UTEP 20155 & $\begin{array}{l}\text { USA, New Mexico, Grant } \\
\text { Co., Bayard }\end{array}$ & JN620828 & JN620978 & JN620869 & JN620909 & JN620943 & JN621016 \\
\hline Crotalus molossus (Chih 1) & UTEP 18677 & $\begin{array}{l}\text { USA, Texas, Hudspeth Co., } \\
\text { IMRS }\end{array}$ & JN620820 & JN620970 & JN620861 & JN620902 & JN620937 & JN621009 \\
\hline Crotalus molossus (Chih 2) & UTEP 14111 & $\begin{array}{l}\text { USA, Texas, Hudspeth Co., } \\
\text { Quitman Mountains }\end{array}$ & JN620831 & JN620981 & JN620872 & JN620911 & - & - \\
\hline Crotalus molossus (Chih 3) & UTEP 14761 & $\begin{array}{l}\text { USA, Texas, Hudspeth Co., } \\
\text { IMRS }\end{array}$ & JN620835 & JN620985 & JN620876 & - & - & - \\
\hline Crotalus molossus (Chih 4) & UTEP 17491 & $\begin{array}{l}\text { USA, Texas, Hudspeth Co., } \\
\text { IMRS }\end{array}$ & JN620821 & JN620971 & JN620862 & JN620903 & JN620938 & JN621010 \\
\hline Crotalus molossus (Chih 5) & UTEP 14148 & $\begin{array}{l}\text { USA, Texas, Hudspeth Co., } \\
\text { Hueco Mountains }\end{array}$ & JN620832 & JN620982 & JN620873 & JN620912 & - & JN621019 \\
\hline Crotalus molossus (Chih 6) & CGA 11 & $\begin{array}{l}\text { USA, New Mexico, Sierra } \\
\text { Co., Kingston }\end{array}$ & JN620829 & JN620979 & JN620870 & JN620910 & JN620944 & - \\
\hline Crotalus molossus (Chih 7) & UTEP 16179 & $\begin{array}{l}\text { USA, New Mexico, Luna } \\
\text { Co., Cooks Range }\end{array}$ & JN620836 & JN620986 & JN620877 & JN620917 & - & - \\
\hline Crotalus molossus (Chih 8) & UTEP 18456 & $\begin{array}{l}\text { USA, Texas, El Paso Co., } \\
\text { Franklin Mountains }\end{array}$ & JN620830 & JN620980 & JN620871 & JN620914 & JN620945 & JN621018 \\
\hline Crotalus molossus (Chih 9) & UTEP 14763 & $\begin{array}{l}\text { USA, Texas, El Paso Co., } \\
\text { Franklin Mountains }\end{array}$ & JN620834 & JN620984 & JN620875 & JN620915 & JN620947 & JN621021 \\
\hline Crotalus molossus (Bigbend 1) & UTEP 19233 & $\begin{array}{l}\text { USA, Texas, Presidio Co., } \\
\text { Shafter }\end{array}$ & JN620838 & JN620988 & JN620879 & JN620917 & JN620949 & JN621023 \\
\hline Crotalus molossus (Bigbend 2) & CGA 06 & $\begin{array}{l}\text { USA, Texas, Jeff Davis } \\
\text { Co., Davis Mountains }\end{array}$ & JN620825 & JN620975 & JN620866 & JN620907 & - & JN621014 \\
\hline Crotalus molossus (Bigbend 3) & UTEP 19788 & $\begin{array}{l}\text { USA, Texas, Brewster Co., } \\
\text { Marathon }\end{array}$ & JN620839 & JN620989 & JN620880 & JN620918 & JN620950 & JN621024 \\
\hline Crotalus molossus (Bigbend 4) & UTEP 18432 & USA, Texas, Jeff Davis & JN620822 & JN620972 & JN620863 & JN620904 & JN620939 & JN621011 \\
\hline
\end{tabular}




\begin{tabular}{|c|c|c|c|c|c|c|c|c|}
\hline & & Co., Davis Mountains & & & & & & \\
\hline Crotalus molossus (Stock 1) & UTEP 19281 & $\begin{array}{l}\text { USA, Texas, Brewster Co., } \\
\text { Christmas Mountains }\end{array}$ & JN620844 & JN620994 & JN620885 & JN620923 & JN620955 & JN621029 \\
\hline Crotalus molossus (Stock 2) & UTEP 17520 & $\begin{array}{l}\text { USA, Texas, Gillespie Co., } \\
\text { Willow City }\end{array}$ & JN620833 & JN620983 & JN620874 & JN620913 & JN620946 & JN621020 \\
\hline Crotalus molossus (Stock 3) & UTEP 17515 & USA, Texas, Hays Co. & JN620846 & JN620996 & JN620887 & JN620925 & JN620957 & JN621031 \\
\hline Crotalus molossus (Stock 4) & CGA 03 & $\begin{array}{l}\text { USA, Texas, Val Verde } \\
\text { Co., Loma Alta }\end{array}$ & JN620824 & JN620974 & JN620865 & JN620906 & JN620941 & JN621013 \\
\hline Crotalus molossus (Stock 5) & UTEP 19994 & $\begin{array}{l}\text { USA, Texas, Terrell Co., } \\
\text { Sanderson }\end{array}$ & JN620823 & JN620973 & JN620864 & JN620905 & JN620940 & JN621012 \\
\hline Crotalus molossus (Stock 6) & UTEP 18415 & $\begin{array}{l}\text { USA, Texas, Pecos Co., } \\
\text { Sheffield }\end{array}$ & JN620847 & JN620997 & JN620888 & JN620926 & JN620958 & JN621032 \\
\hline $\begin{array}{l}\text { Crotalus molossus } \\
\text { (nigrescens 1) }\end{array}$ & JAC 29296 & Mexico, Durango & JN620849 & JN620999 & JN620890 & - & - & - \\
\hline $\begin{array}{l}\text { Crotalus molossus } \\
\text { (nigrescens 2) }\end{array}$ & JAC 29233 & Mexico, Durango & JN620848 & JN620998 & JN620889 & - & - & - \\
\hline Crotalus oreganus $(C$. helleri) & UTEP 17519 & $\begin{array}{l}\text { USA, California, San } \\
\text { Diego Co. }\end{array}$ & JN620814 & JN620964 & JN620855 & JN620896 & JN620931 & - \\
\hline Crotalus tigris & UTEP 18442 & $\begin{array}{l}\text { USA, Arizona, Pima Co., } \\
\text { Tucson Mountains }\end{array}$ & JN620818 & JN620968 & JN620859 & JN620900 & JN620935 & JN621007 \\
\hline $\begin{array}{l}\text { Crotalus totonacus } \\
\text { (Crotalus totonacus } 1)\end{array}$ & SD* & Mexico, Tamaulipas & AY704837 & AY704887 & - & - & - & - \\
\hline $\begin{array}{l}\text { Crotalus totonacus } \\
\text { (Crotalus totonacus 2) }\end{array}$ & $3102 *$ & $\begin{array}{l}\text { Mexico, Queratero, } \\
\text { Tomajo }\end{array}$ & AY704838 & AY704888 & - & - & - & - \\
\hline Crotalus viridis & UTEP 19275 & $\begin{array}{l}\text { USA, New Mexico, Otero } \\
\text { Co. }\end{array}$ & JN620819 & JN620969 & JN620860 & JN620901 & JN620936 & JN621008 \\
\hline Sistrurus catenatus $^{a}$ & Moody 502 & USA, Texas, Haskel Co. & AY223610 & AY223648 & - & - & - & - \\
\hline Sistrurus miliarius $^{a}$ & $\begin{array}{l}\text { UTA-Live } \\
\text { collection }\end{array}$ & $\begin{array}{l}\text { USA, Florida, Lee Co., } \\
\text { Fort Mayers }\end{array}$ & AY223611 ${ }^{\mathrm{a}}$ & $\mathrm{U} 41889^{\mathrm{a}}$ & - & - & - & - \\
\hline
\end{tabular}

*DNA or tissue samples not associated with a collection from the study by Wüster et al. (2005).

${ }^{\mathrm{a}}$ GenBank sample from Parkinson et al. (2002).

${ }^{\mathrm{b}}$ GenBank sample from Wüster et al. (2005). 
APPENDIX II

Specimens Examined

Institutional codes follow Leviton et al. (1985); CGA = C. G. Anderson field series, IMRS = Indio Mountains Research Station. Asterisks indicate specimens not included in morphological analyses.

Crotalus adamanteus - USA: Florida: Baker County: state HWY 127, $1.3 \mathrm{~km} \mathrm{~N}$ of state HWY 122, UTEP 18472*.

Crotalus atrox -USA: Arizona: Maricopa County: state HWY 71, $3.5 \mathrm{~km}$ NE of state HWY 60, $33.9757^{\circ} \mathrm{N}, 113.1410^{\circ} \mathrm{W}, 678 \mathrm{~m}$, UTEP 19051*; Texas: Brewster County: FTM 2627, $4.8 \mathrm{~km}$ SE of US HWY $385,29.6696^{\circ} \mathrm{N}, 103.1232^{\circ} \mathrm{W}, 780 \mathrm{~m}$, UTEP $19849^{*}$.

Crotalus basiliscus-MEXICO: Michoacán: Sierra de Coalcomán, UTA R-6120. Sinaloa: Plomosas, UTA R-6071.

Crotalus cerastes-USA: Arizona: La Paz County: US HWY 95, $10 \mathrm{~km}$ NW of State HWY 72, at mile marker $138,34.0703^{\circ} \mathrm{N}, 114.2597^{\circ} \mathrm{W}$, UTEP $19278^{*}$.

Crotalus cerberus - USA: Arizona: Graham County: Pinaleño Mountains, state HWY 266, 1.4 $\mathrm{km}$ W of Stockton Pass, $32.5973^{\circ}$ N, 109.8657 W, UTEP 19166*.

Crotalus estebanensis-MEXICO: Sonora: Isla San Esteban, USNM 64586 (paratype).

Crotalus oreganus - USA: California: San Diego County: Ko-Pah Mountains, vicinity of North McCain Valley Rd., N of Cottonwood BLM campground, 1350 m, UTEP 17519*.

Crotalus horridus-USA: Texas: Montague County: farm to market road 677, at Taovayas Indian Bridge on Red River, 33.9198 N, 97.5101 W, UTEP 19288*.

Crotalus lepidus - USA: Texas: Presidio County: Fuentes Ranch, $\sim 4$ km (by air) SE of Shafter, $\sim 0.5 \mathrm{~km}$ (by air) WSW Ojo Chilicote, $29.7914^{\circ} \mathrm{N}, 104.2760^{\circ} \mathrm{W}, 1288 \mathrm{~m}$, UTEP $19237^{*}$.

Crotalus mitchellii-USA: California: Imperial County: Black Mountain Rd, $5.5 \mathrm{~km}$ SE of state HWY 78, UTEP 17628*.

Crotalus ornatus-MEXICO: Coahuila: Sierra Encarnación, USNM 46507; Carbonero Canyon, Carmen Mountains, WNW of Múzquiz, USNM 103738; Cuatro Ciénegas (11 km SW of) USNM 159573; USA: New Mexico: Luna County: Cooke's Range, at mouth of Frying Pan Canyon, NW of Starvation Draw, detention dam No. 4, 1554 m, UTEP 16179; Florida Mountains, 32.08633 $\mathrm{N}, 107.61750^{\circ} \mathrm{W}$, USNM 44496; Sierra County: Black Range, HYW 152, $12.6 \mathrm{~km} \mathrm{~W}$ of Hillsboro, near Kingston Ghost Town, 32.91904 N, 107.69004 W, 1843 m, CGA 11*; Socorro County: Questa Spring, in Red Rock Arroyo, San Mateo Mountains, Cibola National Forest, USNM 320318; Texas: Near Pecos River, USNM 486 (holotype); Brewster County: HWY 118, $17.5 \mathrm{~km} \mathrm{~N}$ of state HWY170, $30.03086^{\circ} \mathrm{N}, 104.46840^{\circ} \mathrm{W}, 1581 \mathrm{~m}$, UTEP 19281; Christmas 
Mountains, Terlingua Ranch, west slope of White House Mountain, $29.43333^{\circ} \mathrm{N}, 103.39166^{\circ}$ W, 1219 m, UTEP 11574; on US 90, $24.5 \mathrm{~km} \mathrm{WNW} \mathrm{of} \mathrm{US} \mathrm{385,} \mathrm{30.29703}{ }^{\circ} \mathrm{N}, 103.45428 \mathrm{~W}^{\circ}$, $1419 \mathrm{~m}$, UTEP 19788; $8 \mathrm{~km} \mathrm{~N}$ of Terlingua Ranch Resort headquarters, $29.51666^{\circ} \mathrm{N}$, 103.38333 ${ }^{\circ} \mathrm{W}$, UTEP 11911; Culberson County: Beach Mountains, on state HWY 54, $13 \mathrm{~km} \mathrm{~N}$ of Van Horn, $31.14833^{\circ} \mathrm{N}, 104.81833^{\circ} \mathrm{W}, 1280 \mathrm{~m}$, UTEP 11577; Baylor Mountains, on state HWY 54, $16 \mathrm{~km}$ N of Van Horn, $31.16633^{\circ} \mathrm{N}, 104.84383^{\circ} \mathrm{W}$, UTEP 13799; on state HWY 54, $15 \mathrm{~km}$ N of Van Horn, 31.16000 $\mathrm{N}, 104.83666^{\circ} \mathrm{W}$, UTEP 13026; Guadalupe Mountains, on McKitrick Canyon Rd., $0.8 \mathrm{~km}$ N of US 62/180, 31.94166 ${ }^{\circ} \mathrm{N}, 104.71833^{\circ} \mathrm{W}$, UTEP 8701; El Paso County: Franklin Mountains, residence at 4340 Loma Del Norte in town of El Paso, UTEP 18456*; Tom Mays Memorial Park, canyon to cottonwood springs, $31.91500^{\circ} \mathrm{N}, 106.50333^{\circ} \mathrm{W}$, UTEP 2588; $3 \mathrm{~km}$ E of Red Rock Ranch, $31.87583^{\circ} \mathrm{N}, 106.55100^{\circ} \mathrm{W}$, UTEP 14763; upper McKellegon canyon, on east facing slope, $31.83333^{\circ} \mathrm{N}, 106.48333^{\circ} \mathrm{W}$, UTEP 12058; on Trans Mountain Road, $8 \mathrm{~km}$ W of junction with US 54, $31.88433^{\circ} \mathrm{N}, 106.50400^{\circ} \mathrm{W}$, UTEP 11539 ; Tom Mays Park, 31.91666 ${ }^{\circ} \mathrm{N}, 106.51666^{\circ} \mathrm{W}$, UTEP 11540; Fusselman Canyon, $31.88333^{\circ} \mathrm{N}$, $106.48333^{\circ} \mathrm{W}$, UTEP 228; Hueco Mountains, $31.78333^{\circ} \mathrm{N}, 106.03333^{\circ} \mathrm{W}$, UTEP 3670; 19.3 $\mathrm{km}$ ENE of Horizon City, in western foothills of Hueco Mountains, $31.7350^{\circ} \mathrm{N}, 106.0067^{\circ} \mathrm{W}$, UTEP 3636; Gasline Road, Hueco Mountains, $31.7167^{\circ} \mathrm{N} 106.0167^{\circ} \mathrm{W}$, UTEP 2456; Gillespie County: on Willow City Loop Rd., $6.6 \mathrm{~km}$ N of Willow City, 30.4415 ${ }^{\circ} \mathrm{N}, 98.4985^{\circ} \mathrm{W}$, UTEP 17520; Hays County: 8.0 km (by air) WSW of Wimberly, Rancho Cima, BSA Cockrell River Camp, 29.9542 ${ }^{\circ} \mathrm{N}, 98.16944^{\circ} \mathrm{W}$, UTEP 17515*; Hudspeth County: Eagle Mountains, Marine Ranch House, 30.9222 ${ }^{\circ} \mathrm{N}, 105.0417^{\circ} \mathrm{W}, 1676 \mathrm{~m}$, UTEP 1933; Wind Canyon, $1.6 \mathrm{~km} \mathrm{~W}$ of Eagle Mountain Ranch House, $30.905^{\circ} \mathrm{N}, 105.065^{\circ} \mathrm{W}$, UTEP 1932; east slope of Eagle Bluff, $30.88333^{\circ} \mathrm{N}, 105.06666^{\circ} \mathrm{W}, 1981 \mathrm{~m}$, UTEP 1931; Hueco Mountains, Hueco Ranch Rd, 0.64 km SSW of New Mexico state line, UTEP 14148*; Indio Mountains, N of IMRS headquarters, on road to Squaw Spring, 30.78333 ${ }^{\circ}$ N, $105.01666^{\circ} \mathrm{W}$, UTEP 18677; $3 \mathrm{~km}$ NW of IMRS headquarters, $30.77833^{\circ} \mathrm{N}, 105.02833^{\circ} \mathrm{W}, 1265 \mathrm{~m}$, UTEP 14761; Squaw Creek Canyon, $1 \mathrm{~km}$ SSW of Squaw Spring, 30.79166 N, $105.01666^{\circ} \mathrm{W}, 1219-1311 \mathrm{~m}$, UTEP 11575; Squaw Creek Canyon near Squaw Spring, 30.79666 N, 105.01000 W, 1267 m, UTEP 12184; Purple Sage Mine Rd, $1.8 \mathrm{~km} \mathrm{SW}$ of JCT with main ranch road, $30.76666^{\circ} \mathrm{N}, 105.02000^{\circ} \mathrm{W}$, UTEP 17491; E of IMRS headquarters, $30.77666^{\circ} \mathrm{N}, 105.01500^{\circ} \mathrm{W}$, UTEP 15359; Vicinity of IMRS headquarters, $30.78333^{\circ} \mathrm{N}, 105.01666^{\circ} \mathrm{W}, 1234 \mathrm{~m}$, UTEP 15314; Quitman Mountains, $27.5 \mathrm{~km}$

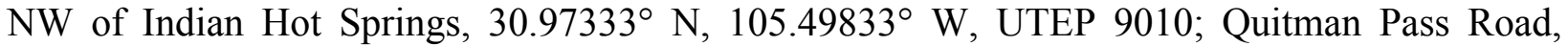
$31.06666^{\circ} \mathrm{N}, 105.46666^{\circ} \mathrm{W}$, UTEP 14111; Jeff Davis County: Davis Mountains, on state HWY $118,9.7 \mathrm{~km}$ N of junction with state HWY $166,30.84316^{\circ} \mathrm{N}, 104.15083^{\circ} \mathrm{W}$, UTEP 6423 ; on state HWY 118, $5.6 \mathrm{~km} \mathrm{~N}$ of junction with FTM 1837, $30.52150^{\circ} \mathrm{N}, 103.77066^{\circ} \mathrm{W}$, UTEP 18432; Limpia Canyon, HWY 17, $29 \mathrm{~km} \mathrm{~N}$ of Fort Davis, $30.7733^{\circ} \mathrm{N}, 103.7531^{\circ} \mathrm{W}, 1270 \mathrm{~m}$, CGA 06*; Pecos County: on FTM 2886, $27.4 \mathrm{~km} \mathrm{~S}$ of junction with I-10, $30.68366^{\circ} \mathrm{N}$, 102.18950 ${ }^{\circ} \mathrm{W}$, UTEP 18415; Presidio County: Fuentes Ranch, 4 km SE of Shafter, $29.79266^{\circ}$ N, 104.27883 ${ }^{\circ} \mathrm{W}, 1228 \mathrm{~m}$, UTEP 19233; Shafter, Fuentes Ranch, 29.79576 ${ }^{\circ} \mathrm{N}, 104.24528^{\circ} \mathrm{W}$, $1290 \mathrm{~m}$, UTEP 19236; on state HWY $170,39.3 \mathrm{~km} \mathrm{~W}$ of Lajitas, $29.35883^{\circ} \mathrm{N}, 104.08750^{\circ} \mathrm{W}$ UTEP 11362; Terrell County: Sanderson, residence near intersection of Blanco St. and railroad tracks, $30.13883^{\circ} \mathrm{N}, 102.39616^{\circ} \mathrm{W}$, UTEP 19994; Val Verde County: Loma Alta, US 277, 1.6 $\mathrm{km} \mathrm{S}$ of Loma Alta, $29.9044^{\circ} \mathrm{N}, 100.7706^{\circ} \mathrm{W}, \mathrm{CGA} 03^{*}$.

Crotalus molossus-MEXICO: Chihuahua: Sierra del Nido, UTA R-17837-38; Arroyo Musteno, 2591 m, UTEP 3052; Between Guadelupe y Calvo and Parral, USNM 46486-87; 
Distrito Federal: Mexico City, USNM 12724; Tlalpan, USNM 4653; Durango: $9.7 \mathrm{~km} \mathrm{SE}$ of Llano Grande UTEP 3982; Nuevo León: UTA R-16147; Oaxaca: $\sim 32 \mathrm{~km}$ NE of Cerro San Felipe, 2591 m, USNM 46467 (holotype [C. m. oaxacus]); San Luis Potosí: Mountains near Jesus Maria, 1829 m, USNM 46425; Sonora: Isla Tiburón, Tecomate, USNM 222084; Bahía Kino (16 km N and $2 \mathrm{~km} \mathrm{E} \mathrm{of)} \mathrm{USNM} \mathrm{240696;} \mathrm{Sierra} \mathrm{San} \mathrm{Luis,} \mathrm{UTA} \mathrm{R-17839-43,} \mathrm{UTA} \mathrm{R-}$ 22457; San Luis Canyon, near Monument 66, Mexican Boundary, USNM 21050; Zapotitlán: Salinas, Puebla, UTA R-25854-56; USA: Arizona: Cochise County: Chiricahua Mountains, 37 $\mathrm{km} \mathrm{W}$ of Apache, $31.46^{\circ} \mathrm{N}, 109.37^{\circ} \mathrm{W}$, UTEP 5993; Canyon behind Fort Huachuca, USNM 17788; Forest Service Rd. 42, 3.2 km SW of Portal, USNM 574196; Gila County: UTA R50685; Greenlee County: Blue River, Cooper Ranch, USNM 51896; Maracopa County: White Tank Mountains, $524 \mathrm{~m}$, UTEP 11953; Forest road 19, near Bartlett Dam, 30.86021 ${ }^{\circ} \mathrm{N}$, $111.71193^{\circ} \mathrm{W}$, UTEP 19091; Mazatzal Mountains, along Picadilla Creek, near Cline's Cabin, 1280 m, UTEP 13794; Pima County: Aravaca Road, 11.6 km E of state HWY 286, UTEP 17505; Santa Catalina Mountains, just off Catalina Highway, $4.7 \mathrm{~km}$ E of Mount Lemon Rd., $975 \mathrm{~m}$, UTEP 13795; Forest Road 70, 8.1 mi SE of Continental, USNM 320314; Santa Cruz County: Atascosa Mountains, Forest road 39, $0.8 \mathrm{~km}$ E of Ruby, $31.4667^{\circ} \mathrm{N}, 111.2317^{\circ} \mathrm{W}$, UTEP 15870; Canello Hills, HWY 83, 5 km S of Lyle Canyon Rd., UTEP 18731; state HWY 83, 1.5 $\mathrm{km}$ W of Canelo, $31.5548^{\circ} \mathrm{N}, 110.5019^{\circ} \mathrm{W}, 1533 \mathrm{~m}$, UTEP 18881; Patagonia Mountains, Harshaw Rd., 5.5 km S of Harshaw Creek Rd., UTEP 16442; Kuncle Mountain, 31.49889 ${ }^{\circ}$ N, 110.70445 ${ }^{\circ}$ W, UTEP 18777; HWY 83, $1.13 \mathrm{~km} \mathrm{~S}$ of West Gates Rd., UTEP 16443; Yavapai County: state HWY 96, 43 km E of state HWY 97, 1000 m, UTEP 18857*; Fort Whipple, USNM 11879, USNM 253070; New Mexico: Catron County: $11.3 \mathrm{~km}$ S of Gila Cliff Dwellings, $33.12553^{\circ} \mathrm{N}, 108.26792^{\circ} \mathrm{W}$, UTEP 3673; Nigrita River, Gila National Forest, USNM 44493; Grant County: US 180 between Silver City and Cliff, $20 \mathrm{~km}$ SE of Cliff, $32.82656^{\circ} \mathrm{N}$, $108.50221^{\circ} \mathrm{W}, 1459 \mathrm{~m}$, UTEP 20156; US 180 between Silver City and Cliff, $17 \mathrm{~km}$ SE of Cliff, $32.84103^{\circ} \mathrm{N}, 108.50952^{\circ} \mathrm{W}, 1459 \mathrm{~m}$, CGA 08*; Fort Webster, Santa Rita Del Cobre mine, USNM 485 (holotype); Bayard, at junction of US 180 and Guinevan St., $32.75204^{\circ} \mathrm{N}$, $108.13613^{\circ} \mathrm{W}$, UTEP 20155; Big Burro Mountains, south rim of Sawmill Canyon, N of Forest Road 836, 32.56833 ${ }^{\circ} \mathrm{N}, 108.47000^{\circ} \mathrm{W}, 1981 \mathrm{~m}$, UTEP 11576; Mimbres Mountains, $3.2 \mathrm{~km} \mathrm{~W}$ of Emory Pass, $32.81666^{\circ} \mathrm{N}, 107.78333^{\circ} \mathrm{W}$, UTEP 533; Pinos Altos Range, state HWY 35, 3.8 $\mathrm{km}$ E of state HWY $15,33.03550^{\circ} \mathrm{N}, 108.18473^{\circ} \mathrm{W}, 1814 \mathrm{~m}$, UTEP 19982; Gila Wilderness, N of Grapevine Campground, along Gila River, $33.23333^{\circ} \mathrm{N}, 108.20166^{\circ} \mathrm{W}$, UTEP 18561; state HWY 35, 0.8 km E of mile marker 22, UTEP 14765; Redrock, USNM 44494; Hidalgo County: Alamo Hueco Mountains, U-Bar Ranch, Horse Canyon, 1646 m, UTEP 11062; U-Bar Ranch, Horse Canyon, 1646 m, UTEP 10756; Animas Mountains, Animas Peak, USNM 44492; Guadalupe Canyon, Monument 73, along Mexican Boundary, USNM 21049.

Crotalus tigris -USA: Arizona: Pima County: Tucson Mountains, foothills of Golden Gate Mountain, Kinney Rd, 3.5 km NW of State HWY 86, UTEP 18442*.

Crotalus totonacus-MEXICO: San Luis Potosí: 11.3 km N of Cuidad de Valles, KU 43569; Tamaulipas: $48 \mathrm{~km}$ S of Soto la Marina, north bridge at Santa Gertrudis, KU 157862; $21 \mathrm{~km} \mathrm{~N}$ of Sota la Marina at km Post 171, KU 174824; Soto la Marina, UTA R-7223-24; La Pesca, UTA R7222 . 
Crotalus viridis - USA: New Mexico: Otero County: CR F001, $18 \mathrm{~km}$ (by road) NE Texas state line $32.07621^{\circ} \mathrm{N}, 105.74593^{\circ} \mathrm{W}, 1537 \mathrm{~m}$, UTEP $19275^{*}$. 
VITA

Christopher G. Anderson began his college career in 2003, completing a B.Sc. in biology at the University of Wisconsin-Stevens Point in December 2007. During his time at UWSP, he worked with the UWSP Herpetology Society and Dr. Erik Wild on various herpetology-related projects. Staring in 2004, Chris took an active role in the UWSP Herpetology Society where he held the offices of advertising coordinator, vivarium manager, vice-president and president. As an undergraduate, Chris received a UWSP student research grant to conduct a survey of reptile diversity in conjunction with a long-term survey of amphibian diversity at Reserva Amazonica, Peru led by Dr. Erik Wild and presented the results at the Joint Meeting of Ichthyologists and Herpetologists. Prior to graduation, he assisted with the curation of the UWSP Herpetology Collection. Chris began the pursuit of a Master of Science degree in biology under the guidance of Dr. Eli Greenbaum at the University of Texas at El Paso (January 2009). As a Masters student, Chris has served as a teaching assistant for Organismal Biology and a collections assistant in the Laboratory for Environmental Biology. He has received two UTEP Graduate School grants to support his research and has presented his research at the Southwestern Association of Naturalists Meeting, the Joint Meeting of Ichthyologists and Herpetologists, and the Chihuahuan Desert Conference. He plans to pursue a Ph.D. in evolutionary biology and would like to take a curatorial position at a museum where he can continue to make contributions to herpetology.

Permanent address: 216 Los Angeles Dr.

El Paso, TX, 79902

This thesis/dissertation was typed by Christopher G. Anderson 